\title{
ANDREAEOBRYUM MACROSPORUM (ANDREAEOBRYOPSIDA) IN RUSSIA, WITH ADDITIONAL DATA ON ITS MORPHOLOGY
}

\section{ANDREAEOBRYUM MACROSPORUM (ANDREAEOBRYOPSIDA) B POCСИИ, С ДОПОЛНИТЕЛЬНЫМИ ДАННЫМИ О ЕГО МОРФОЛОГИИ}

\author{
MichAel S. IGNATOV ${ }^{1,2}$, ElENA A. IGNATOVA ${ }^{1}$, VLADIMIR E. FEDOSOV ${ }^{1}$, \\ OLEG V. IVANOV $^{3}$, ELENA I. IVANOVA ${ }^{4}$, MARIA A. KOLESNIKOVA ${ }^{5}$, \\ SVETLANA V. POLEVOVA ${ }^{1}$, UlyANA N. SPIRINA ${ }^{2,6} \&$ TATYANA V. VORONKOVA ${ }^{2}$ \\ МИХАИЛ С. ИГНАТОВ ${ }^{1,2}$, ЕЛЕНА А. ИГНАТОВА ${ }^{1}$, ВЛАДИМИР Э. ФЕДОСОВ ${ }^{1}$, \\ ОЛЕГ В. ИВАНОВ ${ }^{3}$, ЕЛЕНА И. ИВАНОВА ${ }^{4}$, МАРИЯ А. КОЛЕСНИКОВА ${ }^{5}$, \\ СВЕТЛАНА В. ПОЛЕВОВА ${ }^{1}$, УЛЬЯНА Н. СПИРИНА 2,6 ТАТЬЯНА В. ВОРОНКОВА ${ }^{2}$
}

Andreaeobryum macrosporum is newly found in Yakutia, in the Sette-Daban Mountain Range, ca. $3000 \mathrm{~km}$ west of its known localities in Alaska. This is the first record of the genus and the class Andreaeobryopsida outside of North America. The species was found on calcareous rock outcrops, above the tree line in the Pinus pumila altitudinal belt. The morphology of the Siberian plants is described, focusing particularly on characters less studied in previous observations. Among these are: (1) axillary hairs with a complicated beak structure, apparently regulating mucilage exudation; (2) anacrogyny and the ability to substitute half of a leaf with an archegonium; (3) specific and relatively long sporophyte development within the epigonium, which is filled with mucilage mixed with macerated cells from the inner wall of the epigonium; (4) foot formed by cells with numerous chloroplasts, with inflated surface cells, sometimes forming finger-like protrusions and with the labyrinth ingrowth in 1-3 layers of the foot surface cells and also labyrinth structures on the surface cell wall facing placental space, whereas gametophyte cells have no ingrowth; (5) lobate archesporial tissue, not fully overarching the columella, which has membranaceous connectives between its segments and reaches the poorly differentiated outer spore sac, being thus similar to Andreaea in many respects; (6) flattened seta, which is not due to drying but lacking radial symmetry from the outset; (7) spore walls lacking or almost lacking an exine. It seems that Andreaeobryum plant possesses an ability to concentrate light, as the physiologically important parts of the structure, the haustorial part of the foot, the urn base, the archegoniophores and the meristematic zones near leaf bases, look considerably brighter in comparison with other parts of the plant.

Резюме

Andreaeobryum macrosporum найден в Якутии, на хребте Сетте-Дабан в Верхоянье, примерно в 3000 км западнее ближайшего известного местонахождения на Аляске. Это первая находка и рода, и класса Andreaeobryopsida за пределами Северной Америки. Вид рос на выходах известняка выше границы леса в поясе кедрового стланика. Морфологическое изучение сибирских растений коснулось признаков, недостаточно изученных в предыдущих исследованиях. Были изучены: (1) аксиллярные волоски с выраженным носиком, сложно устроенные и, по-видимому, способные регулировать выделение слизи; (2) анакрогинность и возможность замещения части листа архегонием; (3) специфическое, относительно длительное развитие спорофита внутри эпигония, заполненного слизью, которая смешана с клетками, отслоившимися от внутренней стенки эпигония; (4) стопа, состоящая из клеток с многочисленными хлоропластами, с вздутыми поверхностными клетками, иногда образующими пальцевидные выросты, с лабиринтообразными выростами внутрь стопы в 1-3 поверхностных слоях клеток, а также с похожими лабиринтообразными структурами на поверхности наружного слоя клеток стопы, обращенной к плацентарной полости, в то

\footnotetext{
1 -Faculty of Biology, Lomonosov Moscow State University, Moscow 119991 Russia; e-mail: misha_ignatov@list.ru, arctoa@list.ru, fedosov_v@mail.ru, svetlanapolevova@mail.ru

2 - Tsitsin Main Botanical Garden of the Russian Academy of Sciences, Botanicheskaya 4, Moscow, 127276, Russia; e-mail: winterness@yandex.ru

3 - P.N. Lebedev' Institue of Physics of Russian Academy of Sciences, Leninsky 53, Moscow 119991 Russia, e-mail: ivanov@td.lpi.ru

4 - Institute for Biological Problems of Cryolithozone of Siberian Division of Russian Academy of Sciences, 41 Lenin ave., Yakutsk, 677000, Russia; e-mail: bryo.ivanova@yandex.ru

5 - Moscow Institute of Physics and Technology, 9 Institutskiy per., Dolgoprudny, Moscow Province, 141700, Russia; e-mail: maryco1840@mail.ru

6 - Faculty of Biology, Tver State University, Zhelyabova 33, Tver 170000 Russia; e-mail: ulayspirina@mail.ru
} 
время как соседствующие с этой полостью клетки гаметофита не имеют выростов; (5) лопастная археспориальная ткань, не покрывающая целиком колонку, при этом сегменты колонки соединены между собой пленчатыми перемычками и соприкасаются со слабо дифференцированным наружным споровым мешком, что во многом похоже на строение колонки и археспория Andreaea; (6) уплощенная ножка, изначально не имеющая радиальной симметрии; (7) стенка спор, в которой отсутствует или очень слабо выражена экзина. По-видимому, некоторые части растений Andreaeobryum обладают способностью собирать и проводить свет, поскольку наиболее физиологически важные структуры, такие как гаусториальная часть стопы, основание урночки, архегониофоры и меристематические зоны в основании листьев выглядят более яркими по сравнению с другими частями растения.

Keywords: disjunctive distribution, Asian Russia, axillary hairs, epigonium, placenta, archesporial tissue, seta, spores, exine, mucilage

\section{INTRODUCTION}

Andreaeobryum macrosporum Steere \& B.M. Murray is the latest discovered 'living fossil' amongst mosses: it was recognized only in 1974 from collections by Barbara Murray, and described shortly after that by Steere \& Murray (1976) as a new species and genus. Subsequent study (Murray, 1988) revealed additional unique characters of Andreaeobryum, indicating that it deserved elevation to a separate order, Andreaeobryales B.M. Murray, within the class Andreaeopsida. Among others, Murray (1988) found a considerable similarity of Andreaeobryum with Takakia, at that time referred to hepatics, and primitive liverworts of the class Haplomitriopsida. Molecular phylogenetic studies since their outset have supported an isolated status for Andreaeobryum, suggesting a need to further raise its rank. The formal recognition of the class Andreaeobryopsida was proposed by Goffinet \& Buck (2004). However, according to these phylogenies, Andreaeobryopsida is not intermediate between mosses and hepatics, but close to Andreaea (Newton et al., 2000; Shaw \& Renzaglia, 2004; Chang \& Graham, 2011).

After its initial discovery in Arctic Alaska, Andreaeobryum was recorded from about ten additional localities in Alaska and also in proximal areas of Yukon, the Northwest Territories (west) and northern British Columbia (Murray, 1988; Eckel, 2007; compiled in Fig. 1).

To find Andreaeobryum in Asia was a dream of many bryologists and thus it has been searched for intentionally, especially during field work in Chukotka, Magadan Province and other regions of East Siberia. This search eventually succeeded, but at an unexpectedly greater distance from Alaska. Andreaeobryum has been found ca. $3000 \mathrm{~km}$ west of its nearest locality in North America, in the western part of the Verkhoyansk Mountain Range in Yakutia.

Below we provide details of the locality and plant structure. An exhaustive description of Andreaeobryum has been given by Murray $(1987,1988)$, thus the current description is mostly repetitive, confirming that the $\mathrm{Si}$ berian plants do not strongly differ morphologically from the North American ones. The only difference we noticed is a slightly smaller mean spore size, (50-)70-90(-100) $\mu \mathrm{m}$ vs. (50-)90-100(-120) $\mu \mathrm{m}$, which may depend on a way of measurements. New data on some characters were obtained, mostly from material gathered in the field that was preserved in $2.5 \%$ glutaraldehyde (in phosphate buffer, $\mathrm{pH}=7.4$ ), while some living plants were brought to Moscow and kept alive in a Sanyo 32M climocamera at $+7 /+12^{\circ} \mathrm{C}$. This cultivation was only partially successful and plants did not produce many new shoots. However, a certain growth occurred, allowing study of apical cells and young leaves in living plants.

\section{Cultivation}

\section{MATERIAL AND METHODS}

Living plants of Andreaeobryum were kept in plastic bowls on their original rocky pieces, with moistening once every two weeks with distilled water. They were cultivated with 10 hours light per day, at $+12^{\circ} \mathrm{C}$ during light periods and $+7^{\circ} \mathrm{C}$ at "night". No additional nutrients were added.

\section{Microscopic studies}

Cultivated plants were photographed with a stereomicroscope (Olympus SZX16) equipped with an Infinity 4 digital camera. Some stacked micrographs using several optical sections were composed using the software package HeliconFocus 4.50 (Kozub et al., 2008).

For anatomical observations, material was taken from cultivated plants. Apical parts of shoots were isolated, leaves removed. Prepared stems were de-aerated and fixed in $2.5 \%$ glutaraldehyde in $0.05 \mathrm{M}$ PBS for 3 hours, postfixed with $1 \%$ osmium tetroxide in PBS, $\mathrm{pH} 6.8$, for 6 hours. Then material was dehydrated through an ascending ethanol-acetone series to $100 \%$ acetone. After that samples were embedded in araldite 6005 medium, according to the manufacturer's protocol.

Sections were cut $2 \mu \mathrm{m}$ thick with glass knives, put on glass slides without mounting medium, stained with $0.01 \%$ berberine or its combination with DAPI and scanned under LSCM Olympus FV-1000 based on Olympus BX61, using $473 \mathrm{~nm}$ or combination 405 and $473 \mathrm{~nm}$ lasers. Z-stacks of several scans were usually obtained and presented here.

Living and herbarium material was observed and photographed with LSCM with the similar staining of berberine or berberine/DAPI, without fixation. Combinations of lasers 405, 473 and 576 were used for maximally detailed pictures. Scan series (mostly at $1024 \times 1024$ 


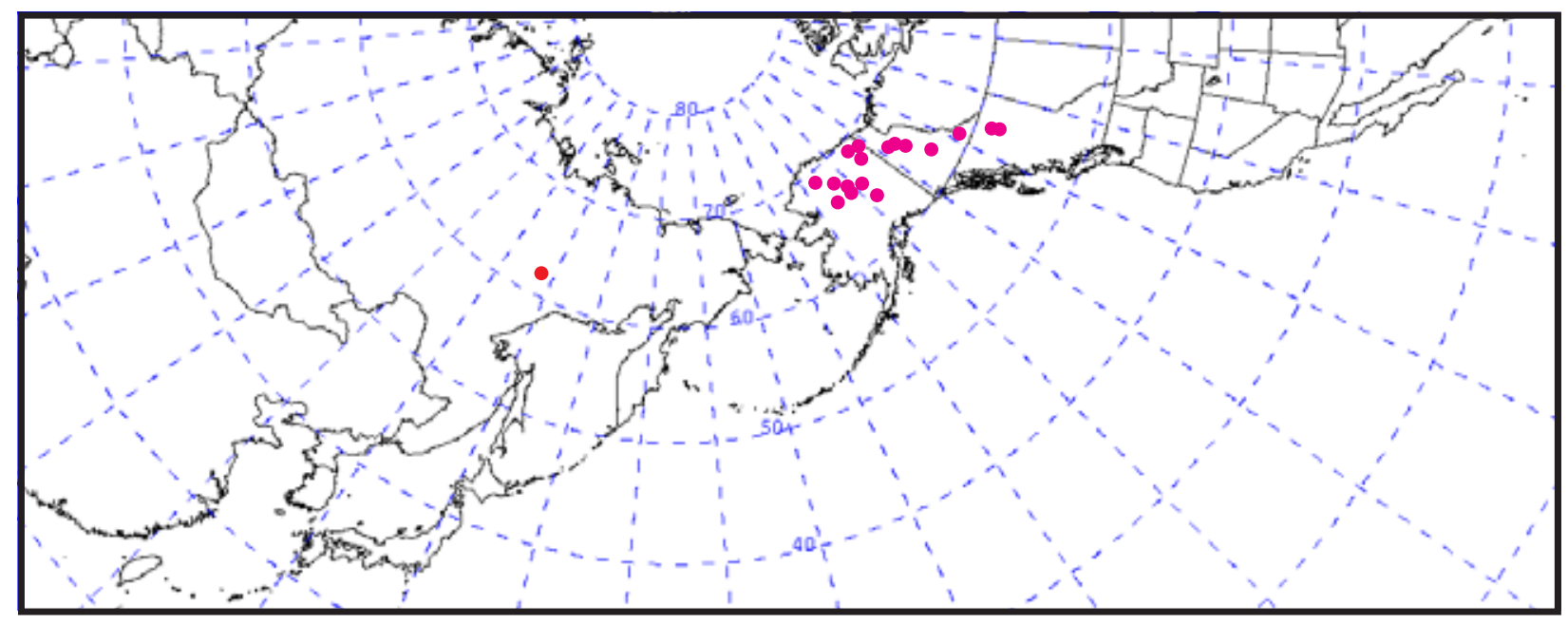

Fig. 1. Distribution of Andreaeobryum macrosporum (expanded from Murray, 1988, using data from databases of MO, NY, LE, and MHA).

pixels, 20-70 scans) are presented here as Z-stacked images, or, in some cases, photo-galleries of parts of series.

For Schiff staining specimens were fixed 24 hours in $10 \%$ aqueous formalin, oxidized for 6 minutes in $0.5 \%$ aqueous solution of periodic acid, washed 10 minutes in running distilled water, placed for $20 \mathrm{~min}$ in Schiff reagent for Graumann, then washed 5 minutes with sulfur water and 10 minutes with distilled water. Indigo carmine $0.5 \%$ solution was used for additional staining of antheridia.

For TEM observations, sectioning (50 nm thick) was done with a Leica-5 ultratome. Sections were studied under JEM-1011 TEM (Jeol, Japan) at $80 \mathrm{kV}$ and a CCD ORIUS SC1000W under control of GATAN Digital Micrograph in the Laboratory of electron microscopy at the Faculty of Biology of Lomonosov Moscow State University. Terminology follows Brown \& Lemmon (1990) and Brown et al. (2015).

SEM observations of gold-coated samples has been done with the SEM Jeol 6380, without additional preparation.

In order to detect the presence of polymerized sporopollenin in the sporoderm a part of the material from each capsule was processed according to the conventional acetolysis scheme, heating the samples in a mixture of concentrated sulfuric acid and acetic anhydride (Hesse et al., 2009).

Element analysis of rock substrate composition was done by X-ray fluorescent analysis with an Axios Advanced spectrometer (Philips Analytical B.V., Netherlands).

\section{LOCALITY}

The Verkhoyansk Mountain Range stretches along the right bank of the Lena River for more than one thousand kilometers. The Sette-Daban Range, meaning "the Seventh Ridge" in the Yakutian language, is located at $59-63^{\circ} \mathrm{N}$, immediately facing the valleys of the Lena River and then its tributary, the Aldan River. Most bedrocks in the Verkhoyansk Mountain System are poor in calcium, but Sette-Daban is an exception. The area of Segenyakh Creek (alternatively named 'Rosomakha Creek') is especially calcareous. On rock fields all along the creek populations of Seligeria spp. are frequent, soil banks in the valley are densely covered by Catoscopium nigritum, Cinclidium stygium, C. subrotundum, and Cyrtomnium hymenophylloides, and at places Orthothecium chryseon is common.

Andreaeobryum grows in the upper course of one of the Segenyakh Creek tributaries, at 970-1100 m elev., surrounded by ridges of 1300-1400 m elev. (Figs. 2A-B). Scattered Larix stands occur in this area up to 800-1000 m, and shrubby Pinus pumila covers the mountain slopes above them with continuous tickets (Fig.2A, E). However, they are only moderately dense, intermingling with rock fields and mountain tundra patches. The latter are mostly lichen communities, as the climate in the area as a whole is quite cold and dry. Andreaeobryum was found on rock outcrops facing the creek valley, which at this level becomes almost dry, with semi-permanent snow-

Table 1. Climate data in nearest meteostations to the Andreaeobryum locality (based on Meteotological annuary of the Yakutsk hydrometeorological centre, 1987-1990).

\begin{tabular}{|c|c|c|c|c|c|c|c|}
\hline Meteostation & location, elev., m & $\begin{array}{l}\mathrm{t}^{\circ} \mathrm{C} \text { annual } \\
\text { mean }\end{array}$ & $\begin{array}{l}\mathrm{t}^{\circ} \mathrm{C} \text { July } \\
\text { mean }\end{array}$ & $\begin{array}{l}\mathrm{t}^{\circ} \mathrm{C} \text { July } \\
\max \end{array}$ & $\begin{array}{l}\mathrm{t}^{\circ} \mathrm{C} \text { Jan } \\
\text { mean }\end{array}$ & $\begin{array}{l}\mathrm{t}^{\circ} \mathrm{C} \text { Jan } \\
\min \end{array}$ & $\begin{array}{l}\text { Precipitation } \\
\text { annual }\end{array}$ \\
\hline Zapadny & $20 \mathrm{~km} \mathrm{E}, 450 \mathrm{~m}$ & -11.3 & +16.5 & +30.7 & -41.0 & -50.1 & 315 \\
\hline Teplyj Klyuch & $65 \mathrm{~km} \mathrm{SWW,} 200 \mathrm{~m}$ & -11.2 & +17.1 & +31.1 & -44.0 & -54.5 & 363 \\
\hline Vostochny & $140 \mathrm{~km} \mathrm{NEE}, 1100 \mathrm{~m}$ & -13.2 & +12.6 & +26.2 & -36.2 & -48.3 & 256 \\
\hline Agayakan & $190 \mathrm{~km} \mathrm{NEE,} 450 \mathrm{~m}$ & -15.1 & +15.0 & +29.7 & -48.2 & -56.2 & 216 \\
\hline Oimyakon & $250 \mathrm{~km} \mathrm{NEE}, 450 \mathrm{~m}$ & -15.5 & +14.9 & +29.4 & -52.3 & -57.9 & 154 \\
\hline
\end{tabular}



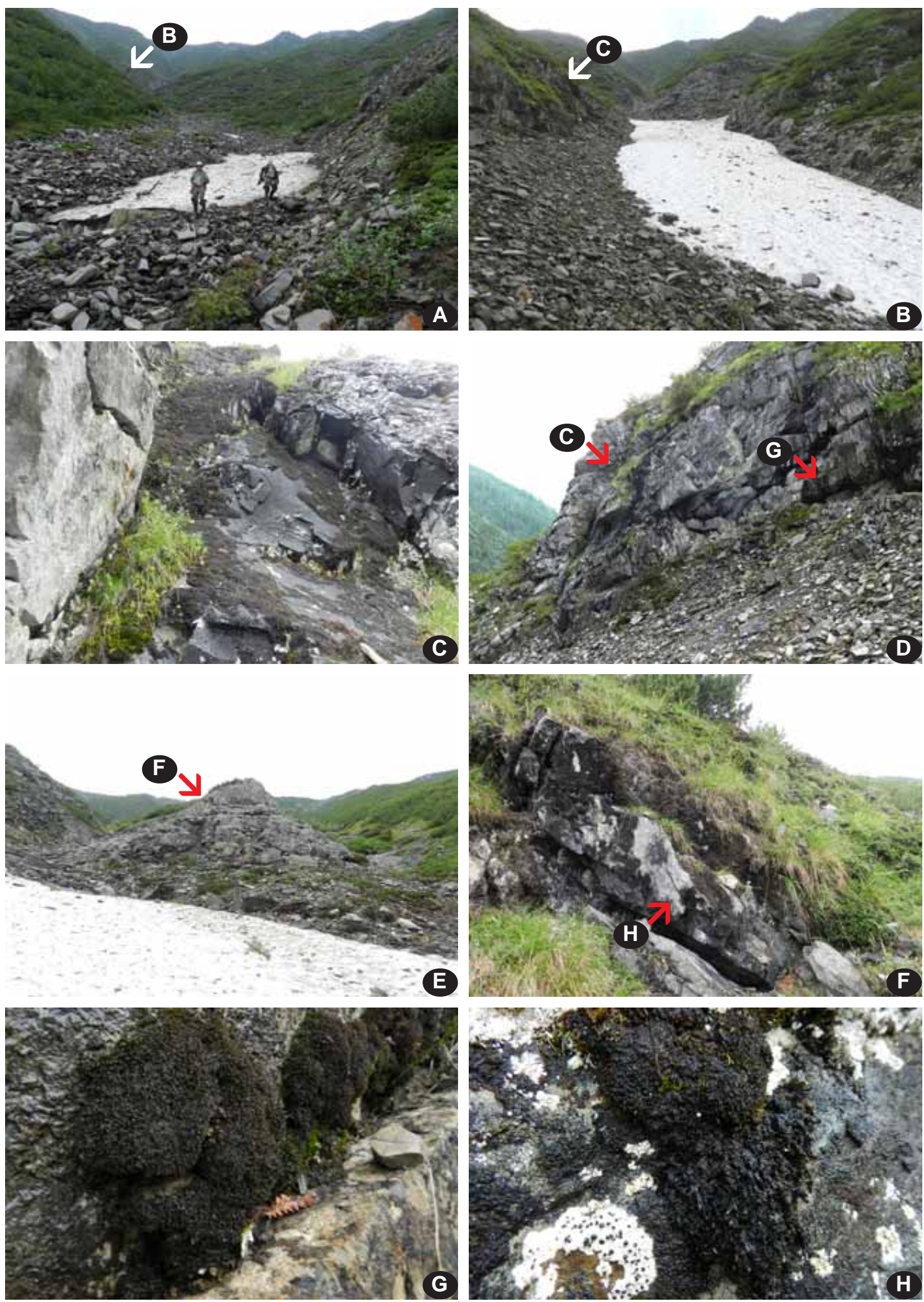

Fig. 2. Habitat of Andreaeobryum macrosporum in Yakutia. A: photo from $970 \mathrm{~m}$ elev. B-D, H: at $1070 \mathrm{~m}$, E-F: at $1100 \mathrm{~m}$. 

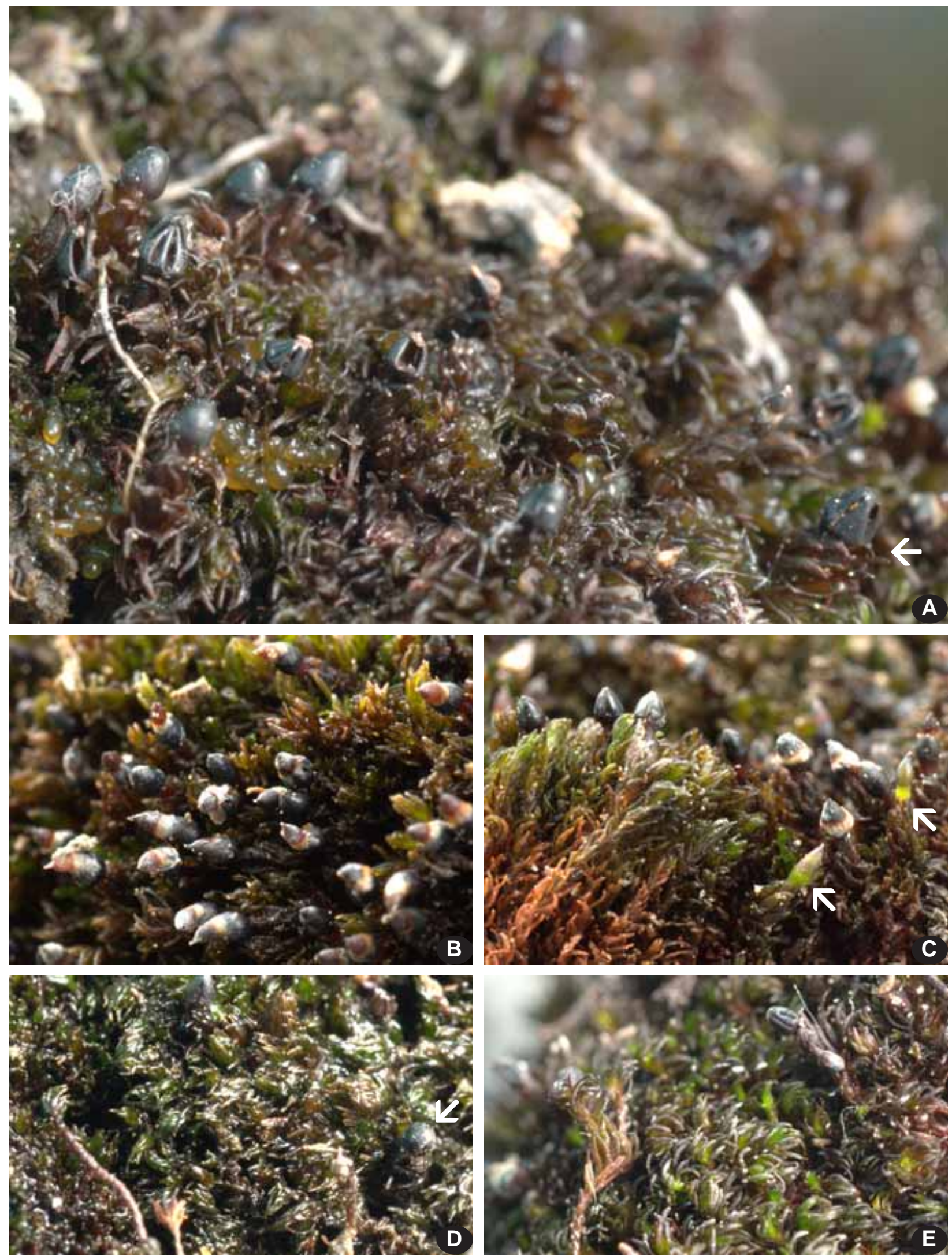

Fig. 3. Habit of Andreaeobryum macrosporum (photographs taken from living plants, transported to the camp on original rock pieces). A: Plants with mostly open and partly broken capsules, arrowed is the capsule with spores seen among valves. B: Capsules within bicolored calyptrae. C: Tuft with capsules at various stages of maturation, including some still embedded in epigonium; note a bright base of the latter (arrowed, cf. Fig. 16A). D: Tuft with some shoots with julaceous foliage in basal part; note round premature capsule (arrowed). E: Tuft with male plant in the central part of photograph, with perigonia conspicuous due to lighter and brighter green color. 
Table 2. Rock composition (surface sampling of piece with Andreaeobryum macrosporum).

\begin{tabular}{lrlr} 
Element & $\%$ & Element & ppm \\
$\mathrm{Na}_{2} \mathrm{O}$ & 0.08 & $\mathrm{~V}$ & 18 \\
$\mathrm{MgO}$ & 2.75 & $\mathrm{Cr}$ & 13 \\
$\mathrm{Al}_{2} \mathrm{O}_{3}$ & 0.53 & $\mathrm{Cu}$ & 28 \\
$\mathrm{SiO}_{2}$ & 4.75 & $\mathrm{Zn}$ & 18 \\
$\mathrm{P}_{2} \mathrm{O}_{5}$ & 0.050 & $\mathrm{Rb}$ & 12 \\
$\mathrm{~S}$ & 0.030 & $\mathrm{Ba}$ & 43 \\
$\mathrm{~K}_{2} \mathrm{O}$ & 0.24 & $\mathrm{Sr}$ & 624 \\
$\mathrm{CaO}$ & 45.29 & $\mathrm{Zr}$ & 12 \\
$\mathrm{MnO}$ & 0.014 & $\mathrm{~Pb}$ & 6 \\
$\mathrm{Fe}_{2} \mathrm{O}_{3}$ & 0.46 & & \\
\hline
\end{tabular}

fields along its bottom (Fig. 2B). The lowest snow was found in mid August at $1000 \mathrm{~m}$ elev. (Fig. 2A), while the main Andreaeobryum population was located near the next snow-field, at $1070 \mathrm{~m}$ (Figs. 2B).

The largest population of Andreaeobryum was found on the inclined face of an outcrop, sloping at ca. 50-60 and apparently permanently irrigated by seepage from melting permafrost (Figs. 2C-D). Smaller cushions were observed here and there on nearby outcrops (Figs. 2G-H) with the highest patch at $1100 \mathrm{~m}$ (Figs. 2E-F). We failed to find Andreaeobryum in neighboring areas a few hundred meters upstream in this creek simply because of the absence of appropriate habitats, while further areas were unexplored because of our fieldwork schedule. The lowermost locality at $970 \mathrm{~m}$ was on the rock of the creek bar (cf. Fig. 2A), having obviously become detached from the outcrop and unlikely to persist as a new population, but nontheless having been able to survive for a considerable period (judging from the fact that it covered the entire upper surface of this rock ca. $15 \mathrm{~cm}$ across).

Rocks and fine soil above them were boiled after acetic acid treatment. The outcrops cracked into rather orthogonal blocks at right angles, which is typical for limestones. One piece of rock collected from the surface, immediately under an Andreaeobryum tuft, was analyzed for chemical elements, revealing a high content of $\mathrm{CaO}$ $(45.3 \%)$ and indicating that it was almost pure calcium carbonate. Table 2 shows the content of some other elements, which is very low $(\mathrm{Cl}, \mathrm{Ti}, \mathrm{Ga}, \mathrm{As}, \mathrm{Br}, \mathrm{Y}, \mathrm{Nb}, \mathrm{Mo}$, $\mathrm{Hf}, \mathrm{Co}, \mathrm{Ni}$ ).

Meteorological data are available for five places in the Vernkoyansk Mountain System, more or less proximal to the Segenyakh Creek (Table 1). The climate is indeed very cold. Permafrost in this part of Yakutia is over $700 \mathrm{~m}$ thick (http://www.syl.ru/article/197798/new_vechnaya- merzlota-vechnaya-merzlota-na-karte-rossii), and in the lower course of the Segenyakh Creek, at ca. 500 m elev., ice was detected by us in mid August 40-20 cm under Hylocomium, Rhytidium, Sphagnum, and Cladonia stellaris carpet in an open Larix stand. The locality of Andreaeobryum at $1070 \mathrm{~m}$ elev. is obviously colder, being adjacent to a late snow bed and seeped by ice water from melting permafrost. As the ridge with Andreaeobryum is one of the westernmost in the area, exposed to the prevailing westerly winds from the lowlands of the Central Yakutia, it seems that the locality collects additional moisture, and is likely to be considerably more humid compared to the figure of $315 \mathrm{~mm}$ nearby at $450 \mathrm{~m}$ elev.

\section{MORPHOLOGY}

Andreaeobryum macrosporumSteere \& B.M. Murray, Phytologia 33: 407. 1976.

Figs. 2-39.

Plants in moderately dense tufts, intense smaragdine green in recently formed parts, readily turning to dark brown. Stems ascending to erect, but as the species grows usually on inclined to vertical surfaces, stem tips face downwards (towards the substrate), with the longer leaves facing in the same direction; repeatedly branched by subterminal innovations; rather slender, red-brown, 2-3(-7) $\mathrm{cm}$ long (including old parts), 100-150(-200) $\mathrm{mm}$ in diameter, without hyalodermis and central strand, sclerodermis consisting of 1-2 layers of thick-walled cells, except the distal parts of fertile shoots, where stem is composed of completely homogeneous, moderately thickwalled cells; central strand absent; foliage dimorphous, some shoots vermicular, densely julaceously foliate with small orbicular leaves; other shoots moderately densely foliate with much longer leaves turned to one side, usually towards the substrate; julaceous shoots with age usually start to develop longer leaves, but sometimes remain thin and julaceous indefinitely and form a part of the tuft with shoots exclusively of this type; transitional zone from small-leaved to large-leaved part of shoot is most commonly quite abrupt, occasionally gradual; in upper fertile parts of shoots foliage becomes more variable, involving small primary leaves in addition to large leaves; rhizoids ${ }^{1}$ copious at stem bases, forming brownish mat, transforming to secondary persistent protonema that produces new stems and terete protonemal leaves; axillary hairs beaked, few in leaf axils, becoming elevated one cell up on adaxial leaf surface with age, most numerous in the fertile zone of the female plants; usually two-celled, with upper cell beaked. Axillary hairs that appear maximally developed, judging from the most inflated apical cell, to $15-16 \mu \mathrm{m}$ wide. Most beaked axillary hairs twocelled, 30-50×10-15 $\mu \mathrm{m}$, but occasionally with basal cells up to five in number, and occasionally even more.

Leaves dimorphic in two types of shoots. Small orbicular to broadened orbicular leaves $0.2-0.3 \mathrm{~mm}$ long and $0.3-0.4 \mathrm{~mm}$ wide, ecostate, concave. Larger leaves erect, moderately falcate-secund, 1.2-1.7 mm long, 0.2 $0.3 \mathrm{~mm}$ wide, lanceolate, from ovate base gradually tapered to bistratose acumen $1 / 5-1 / 2$ the leaf length, slightly concave-channeled; margins plane, entire to slightly sinuose; cells of unistratose lamina in lower part of leaves

\footnotetext{
${ }^{1}$ - Boldfaced structures are discussed additionally below.
} 


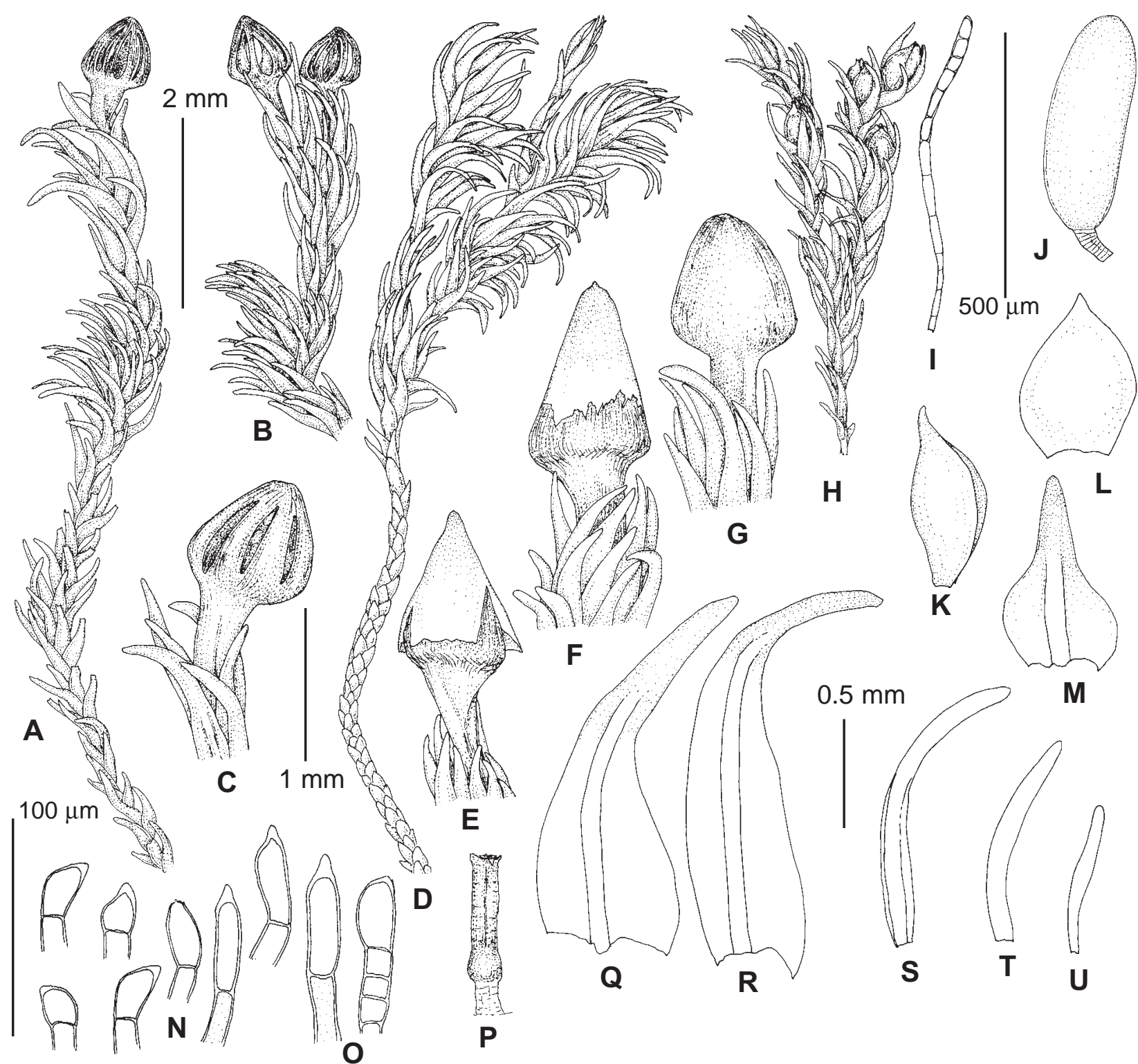

Fig. 4. Andreaeobryum macrosporum Steere \& B.M. Murray (from: Russia, Yakutia, Segenyakh Creek, Ignatov \& Ignatova 15-599, MHA). A-B - plants with sporophytes, dry; C - opened capsule, dry; D - female plant; E-F - capsules with calyptra; G - closed capsule; $\mathrm{H}$ - male plant; I - paraphysis; J - antheridium; $\mathrm{K}-\mathrm{M}$ - perigonial leaves; $\mathrm{N}-\mathrm{O}$ - beaked axillary hairs; P archegonium; Q-R - perichaetial leaves; S-U - primary leaves. Scale bars: $2 \mathrm{~mm}$ for A-B, D, H; $1 \mathrm{~mm}$ for C, E-G; $0.5 \mathrm{~mm}$ for KM, Q-U; $500 \mu \mathrm{m}$ for I-J; P; $100 \mu \mathrm{m}$ for N-O.

irregularly rounded, $10-25 \mu \mathrm{m}$ in diameter, towards the base larger and longer, short rectangular, 20-40×15-28 $\mu \mathrm{m}$, with thick, but with apparently soft walls; costa confluent with upper 2- to 5-stratose acumen, without apparent differentiation in transverse section, or central cells in middle with narrower lumens.

Dioicous. Perigonia bulbiform, terminal, but antheridia also occurring in axils of 1-2 leaves adjacent to perigonia; perigonial leaves broadly ovate, short apiculate, unistratose throughout; antheridia 250-350 $\mu \mathrm{m}$ long, to $150 \mu \mathrm{m}$ wide when mature, on 2-seriate stalks to $80 \mu \mathrm{m}$ long; up to 7 , and often exhibiting different stages of development. Archegonia not surrounded by specialized perichaetial leaves, scattered along the up- permost part of stem, sometimes to $1 \mathrm{~mm}$ long, often associated with small 'primary leaves'. Sporophytes appearing terminal, but as the lateral archegonia are sometimes fertilized, their position appears somewhat shifted from the apex, and rarely two capsules are developed on one stem. Seta reddish-black, of the same color as the capsule, flattened and twisted. Capsule reddishblack, shining, originally globose, then conic distally and trullate-shaped in side view; $0.5-0.7 \times 0.5-0.7 \mathrm{~mm}$, dehiscent longitudinally by $4-8$ slits; valves remaining connected for a long time; stomata absent. Calyptra large, enveloping the whole capsule, persistent. Spores orange to brownish with age, $(50-) 70-90(-100) \mu \mathrm{m}$, spheric to irregularly ovate, granulose, multicellular. 


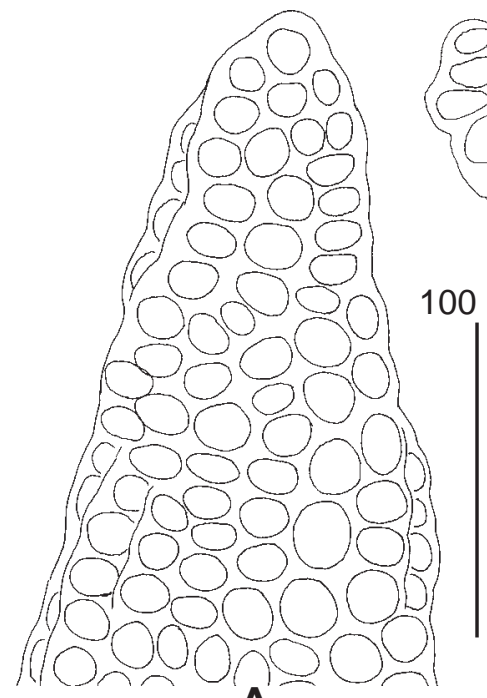

$A$

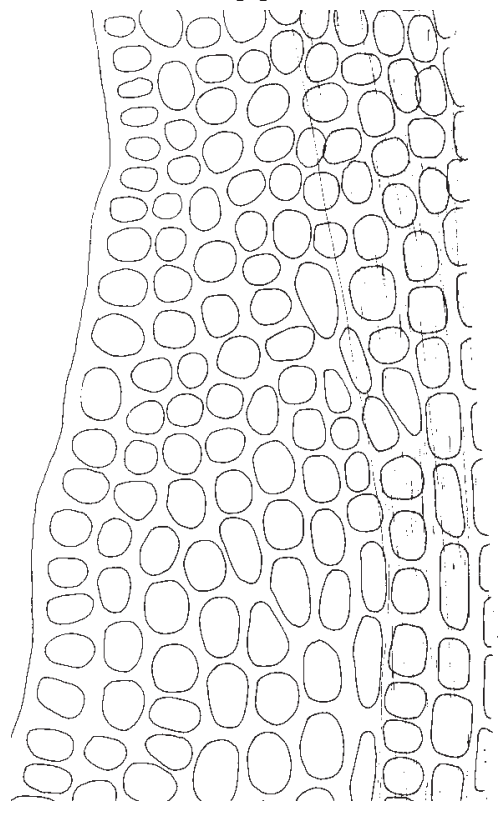

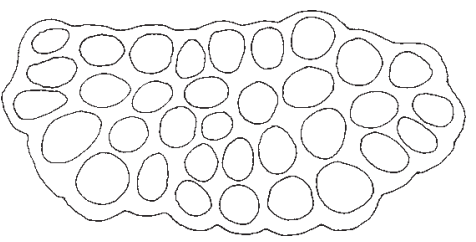

B

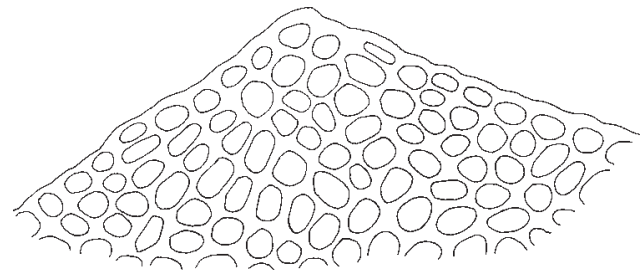

C
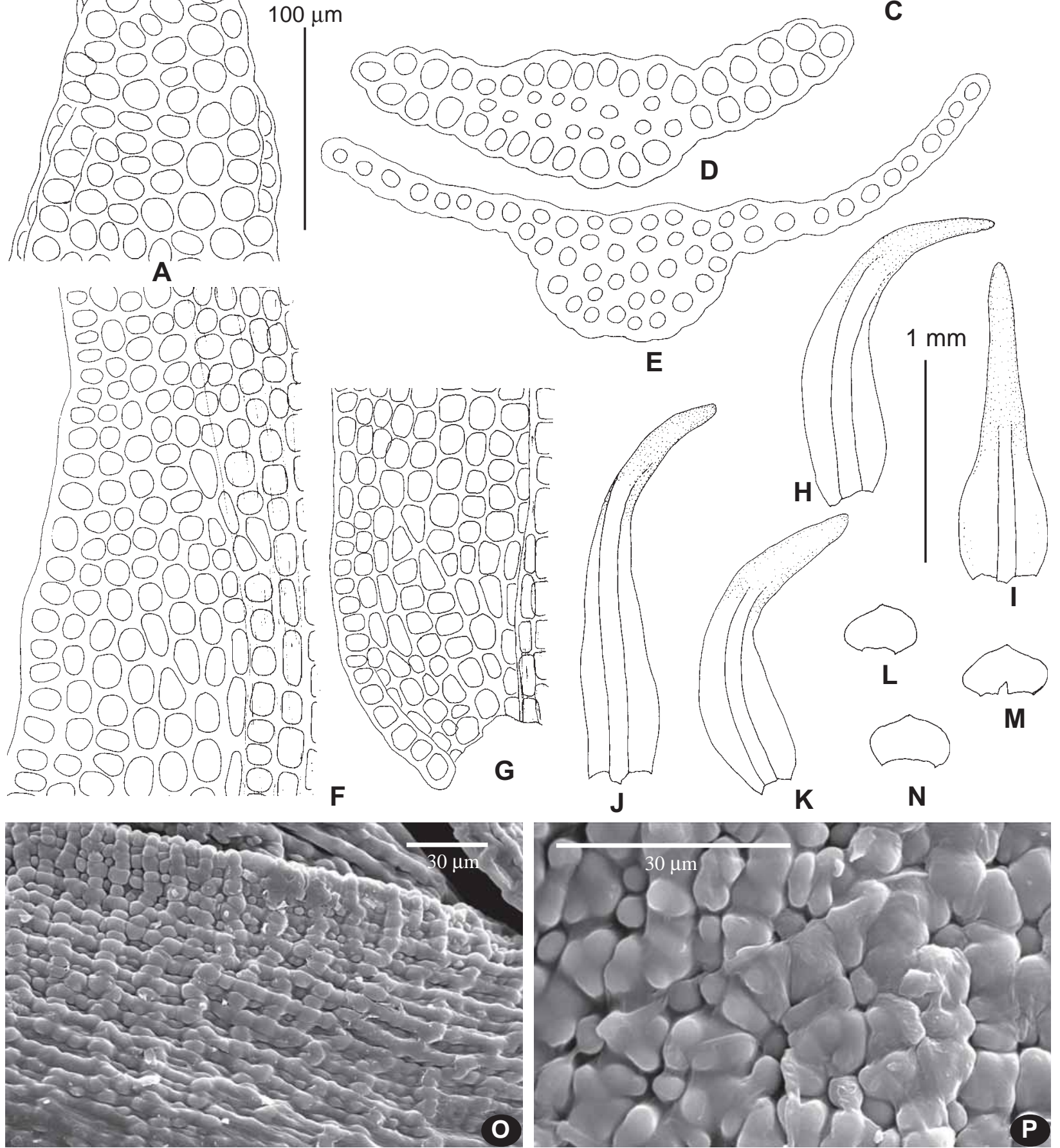

Fig. 5. Andreaeobryum macrosporum (from: Russia, Yakutia, Segenyakh Creek, Ignatov \& Ignatova 15-599, MHA). O-P: SEM (herbarium specimens, coated without drying in critical point). A - distal leaf cells; B - transverse section at distal part of leaf; C - distal cells of leaf from julaceous shoot; D - transverse section at mid-leaf; E - transverse section at the basal part of leaf; F - median leaf cells; G - basal leaf cells; H-K - stem leaves; L-N - leaves from julaceous shoot; O - dorsal leaf surface; P ventral leaf surface. Scale bars: $1 \mathrm{~mm}$ for $\mathrm{H}-\mathrm{N} ; 100 \mu \mathrm{m}$ for $\mathrm{A}-\mathrm{G}$. 

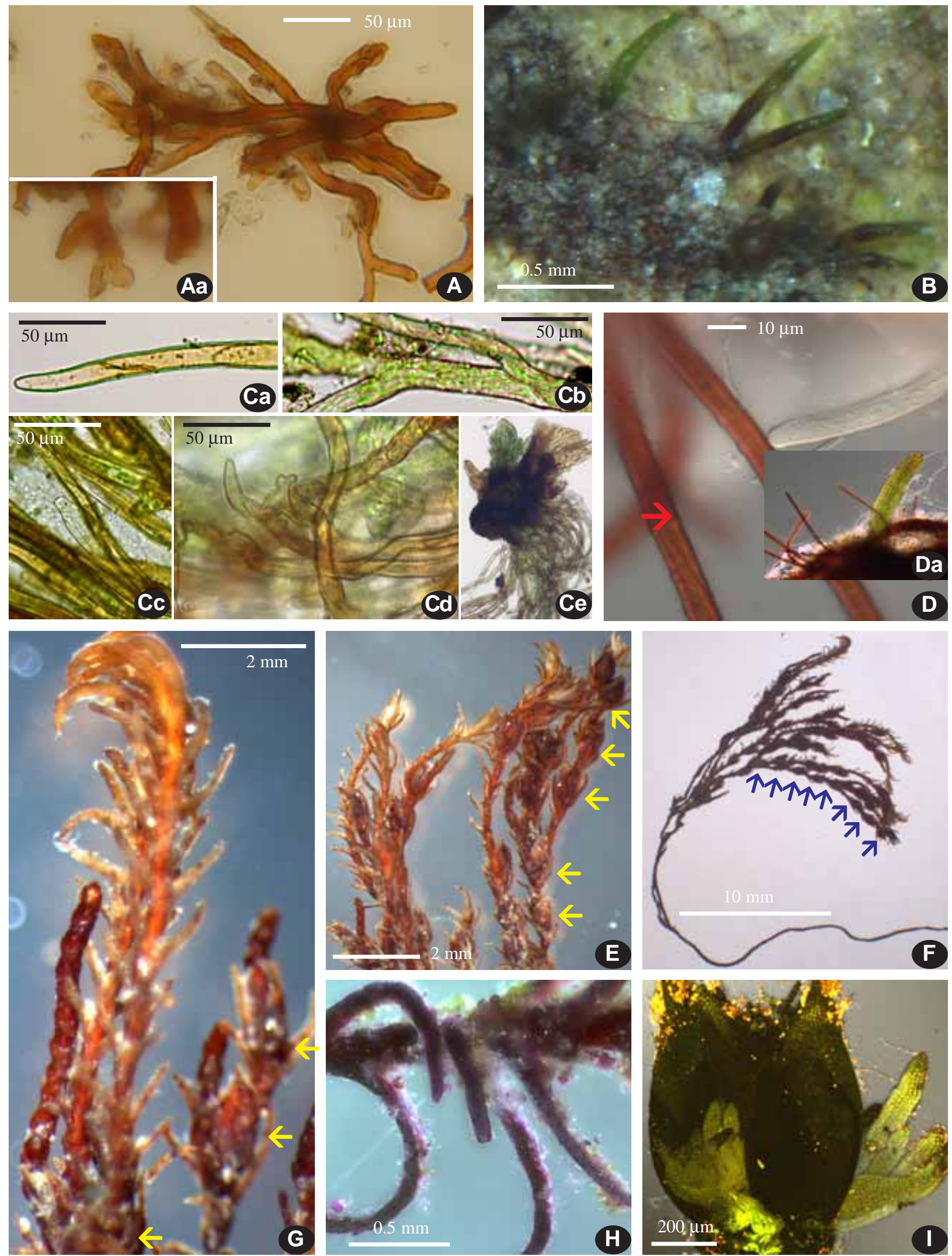

Fig. 6. Andreaeobryum macrosporum (A, C, D: LM; B, Da, E-H: SM; I: LSCM, living plants). A: Protonema forming a mass upon rock surface in 'B'. B: Protonema with protonematal leaves upon rock surface. C: Rhizoids from young innovation 'Ce', showing variation in their structure (see text for discussion). D: Rhizoids arising from the wounded shoot (cf. Da); note strongly oblique wall between cells. E-G: male plant, perigonia arrowed; note dimorphism of innovations in ' $\mathrm{G}$ '. H: Shoot with leaveas covered by calcareous material, apparently cemented by moldy bacterial layer upon leaves. I: Perigonium with two young innovations. 
Rhizoids (Fig. 6) occur as extensive light brownish mats at the shoot base and also near wounded parts of stem and at base of innovations (probably also appearing in injured parts of moss body).

In the former case, the mass of rhizoids was observed on rock surface, being intermingled with sand pieces and thus forming a specific adhesions upon rocks. These formations apparently follow paths of water flows on the inclined rock surface below moss cushions. Terete protonemal leaves often originate along these 'paths' (Fig. $6 \mathrm{~B})$. Rhizoids in these mats have extremely thick-walled cells, with lumen often unseen at all or seen as a 'median line' - a poorly discernible line along the cell middle (Fig. 6A). In a few places, however, the oblique walls between cells are seen, confirming identity of the rhizoids.

Many ends of cells in these mats are of irregular shape, swollen and sucker-shaped, facilitating an attachment to the substrate.

Rhizoids from innovations are even more irregular, changing their stature during maturation. At first they are thin-walled and hyaline (Fig. 6D), with walls between cells oblique at about $30^{\circ}$. Cell divisions in rhizoids occur at ca. $10^{\circ}$ (Fig. 6Ca). Later rhizoid cell-walls may become brown and thick, with an unusually narrow angle between cells, ca. $10^{\circ}$ (Fig. 6D). In another case we observed rhizoids branched at very narrow angle, thus at place of branching the daughter cell followed mother cell, making rhizoids bicellular in width (Fig. 6Cb); in these zones rhizoids are hyaline, not brownish, and include numerous small chloroplasts (Fig. 6Cb). In older parts within rhizoid bundles, some chloronemata filaments were terminated in beaked-shaped cells (Fig. 6Cc), while others ended in a swollen and coral-shaped cells (Fig. $6 \mathrm{Cd})$. The beaked outlines were observed in rhizoid mass (Fig. 6A). This is still an opened question, if the beakedshape in some rhizoid cells correspond to any mucilage production in them.

Protonemal leaves occur on mats of rhizoids (Fig. 6B). They are cylindric and multistratose throughout. Their transverse sections were presented by Murray and they are nearly identical to those of primary leaf transverse sections, shown, e.g., in Fig. 14.

Beaked axillary hairs (Figs. 7-8). A peculiar structure of the axillary hairs of Andreaeobryum was pointed out by Murray $(1987,1988)$. They have a conspicuous beak, which provides the mucilage release through the apical pore, in a way somewhat similar to Takakia, and, supposedly, in none of other mosses. Murray (1988) also indicated that axillary hairs are occasionally not beaked and are closed distally. At the same time, they are still not the same as in Andreaea, which has axillary hairs of the same type as other mosses.

The polymorphism of axillary hairs has been reviewed by Hedenäs (1990) for pleurocarpous groups, while their variation in acrocarpous species was only briefly discussed by Zolotov \& Ignatov (2001). Axillary hairs in mosses are formed by $1-2$ short brownish basal cells and $1-5(-10)$ upper cells which are usually longer, thin-walled, hyaline, rounded at apex. The release of mucilage is not very well studied, but likely it never has any definite place of liberation.

Although both opened and closed axillary hairs occur in the Siberian plants, we think that the closed axillary hairs represent just an older stage, after an active period of the mucilage release, or can be simply underdeveloped ones. Moreover, the exact interpretation of a given individual axillary hair might be uncertain due to the fact that the 'beaked' pattern can be seen also in apical cells of rhizoids (Fig. 6Cc) and apical cells of paraphyses (Fig. 12E).

However, in the areas where axillary hairs are especially abundant, for example, near gametangia and beside the stem apical cell (Fig. 13F, H), the beak is always apparent. Near these places it is easy to find some older beaked axillary hairs, with broken apical nipple (Fig. 7D) and then their apical cells are approaching to the rounded shape of distal end, looking somewhat similar to ordinary moss axillary hairs, albeit with still thicker cell walls (Fig. 7H). Rounded apical cells of axillary hairs were also seen in longisections of plants (Fig. 7G), but such observation is misleading, as the beak in not always strictly apical and often turned to one side, thus the beak can be seen only in one of several 1-2 $\mu \mathrm{m}$ sections.

Murray (1988) indicated the similarity of Andreaeobryum with Takakia in apical mucilage release from the axillary hairs. This statement is confirmed by our observations, but there are also some differences (Fig. 7M-N). In Takakia, the release is explosive through the somewhat attenuate tip of the axillary hair, and a round droplet appears first at the torn tip, sometimes followed by abundant exudation, when droplet reaches in diameter two lengths of the axillary hair which produces it (Fig. 3 in Schuster, 1966). The mucilage papillae in hepatic may have the shape similar to Takakia and Andreaeobryum (Galatis \& Apostolakos, 1977), but no special structures near the tip of axillary hair were found by TEM studies (Galatis \& Apostolakos, 1977; Duckett et al., 1990).

However, Takakia is not the only moss other than Andreaeobryum, that has an apical mucilage release. The latter is characterisic also of Sphagnum, which it seems, has never been discussed before, despite of a special description, e.g., in Berthier et al. (1974). The axillary hairs in Sphagnum are two-celled, with an inflated apical cell and a rather inconspicuous apical structure (Fig. 7R). However, autofluorescence contrasts it enough to make certain that the apical pore occurs (Figs. 7O-Q) and we were able to see it in every sample of living plants of $S$. girgensohnii and S. magellanicum examined.

Compared to Takakia and Sphagnum, Andreaeobryum has an extraordinarily complicated axillary hairs (Figs. 7-8). 

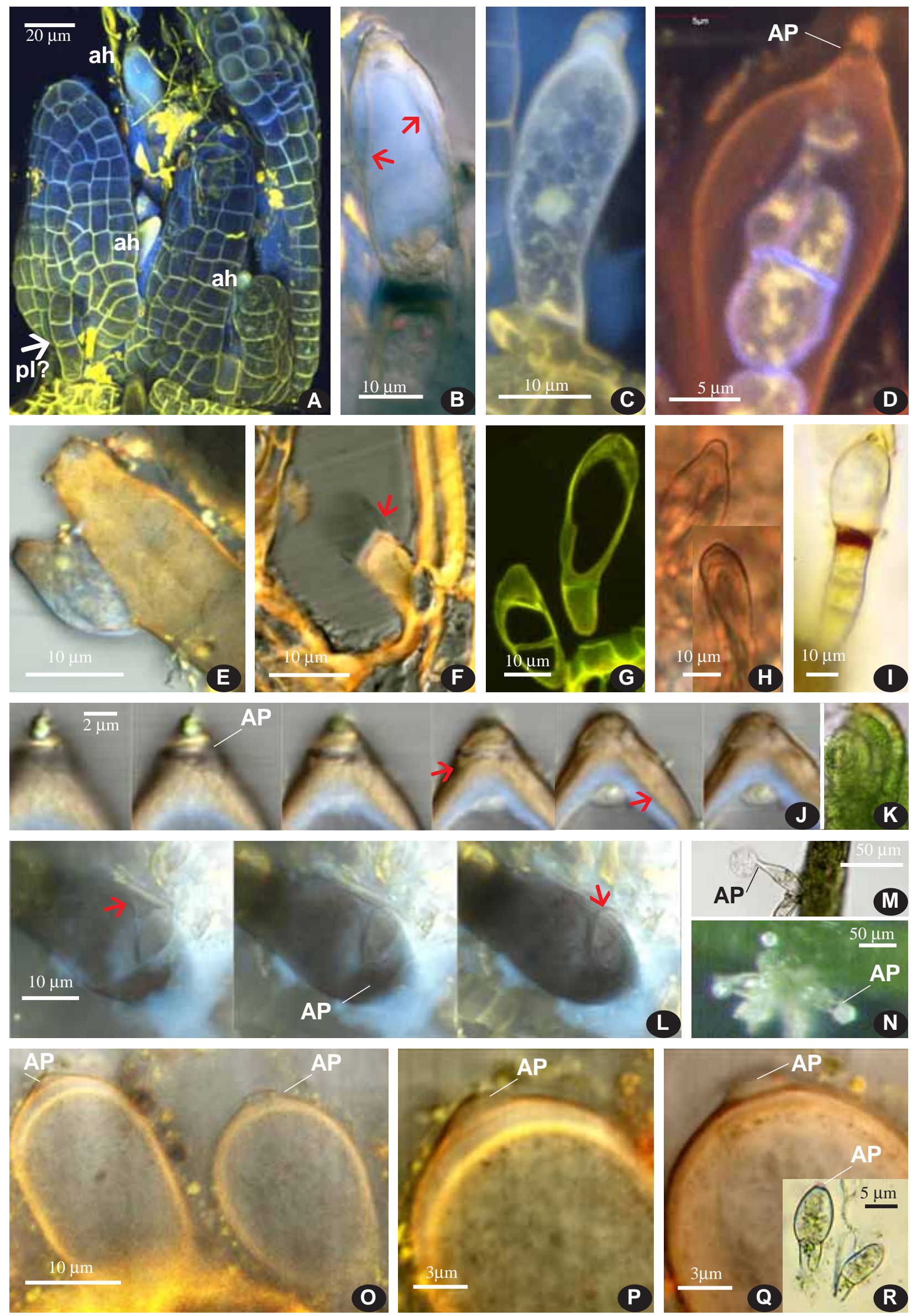

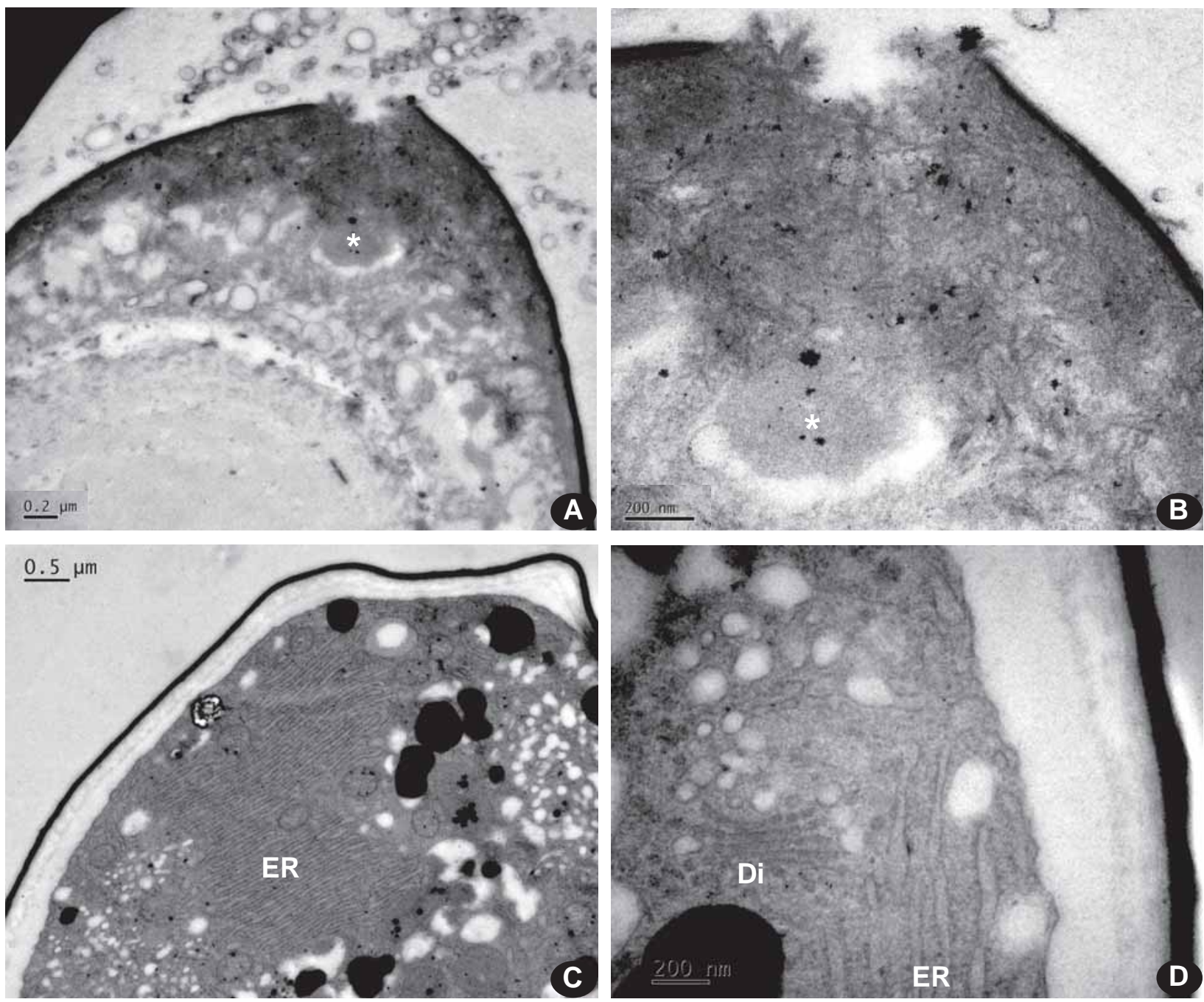

Fig. 8. Andreaeobryum macrosporum (TEM). Axillary hairs from the area near the end of foot (sections transverse to foot and also representing transverse sections of the axillary hairs in their middle part (' $\mathrm{C}-\mathrm{D}$ '), while for some axillary hairs bent to one side the apical part has also been available for study ('A-B'). A: the apical part of the axillary hair, showing a place of mucilage release (looking like a pore, it is rather a transverse section of a rupture, shown in Figs. 7J and 7L); drops of hygrophobous compounds occur near the 'pore'; among the complex structure below the pore, there is one most massive conic 'reservoir' (marked with asterisk*), $0.8 \mu \mathrm{m}$ wide and $0.6 \mu \mathrm{m}$ long, at the distance ca. $1 \mu \mathrm{m}$ below the pore; its proximity is especially rich in fibrillose network, apparently participated in the regulation of the mucilage discharge. B: close up of A, for surrounding of pore and 'reservoir', surrounded by bundles of these fibrils. C-D: part of transverse section of the axillary hair, showing extensive endoplasmatic reticulum (ER) and dictyosome (Di), as well as a complex trilayered wall of the cells formed axillary hair.

Fig. 7. (previous page) Andreaeobryum macrosporum (living, A-L), Takakia lepidozioides (living, M-N) and Sphagnum girgensohnii (living, O-R) axillary hairs with apical pore (AP), position and structure (A-G, J, L, O-Q: LSCM; H-I, K, M, R: LM; N: SM). A: Leaves crowded at shoot apex; note beaked axillary hairs (ah) and putative filamentose primary leaf (PL?). B-I: axillary hairs. C: still not opened axillary hair. E: axillary hair with protoplast fallen out, so looking as branched in LM. J and L: apical parts of axillary hairs. K: a bud, propagated in perigonium of old plant, with few young orbicular leaves and axillary hairs, studied in living state and presented in Figs. C, E, J and L. Note that B,F, J and L illustrate an armature of apical cell, apparently regulating mucilage release. Takakia pictures show mucilage release through the apical pore (AP). Sphagnum 'P' and 'Q' are close ups of 'O'.

The structure is difficult to see in the light microscope (e.g., in Figs. 7H-I, 14B), but autofluorescence contrasts it. Figs. 7B, J and L illustrate sublongitudinal fibrils, which reach the apical pore mouth and connect to the circular cup-like cover of the pore. It seems that the shift of this cover allows the mucilage discharge (Fig. 7L). These sublongitudinal fibrils often make the cell somewhat angulose, so basal cells can be assumed as a quadrate-shaped in transverse section (Fig. 7F).
TEM images illustrate that the body of the axillary hairs are rich in endoplasmatic reticulum and dictyosomes (Figs. 8C-D). The beak area has abundant fibrillose structures that form a net shortly below the apical pore (or rupture) (Figs. 8A-B). Shortly below the apical pore a conic structure is seen (Fig. 8B). There are especially abundant fibril bundles around it, and this fact along with structure and position below pore allow to propose its function as a reservoir of mucilage, which release can be regulated. 

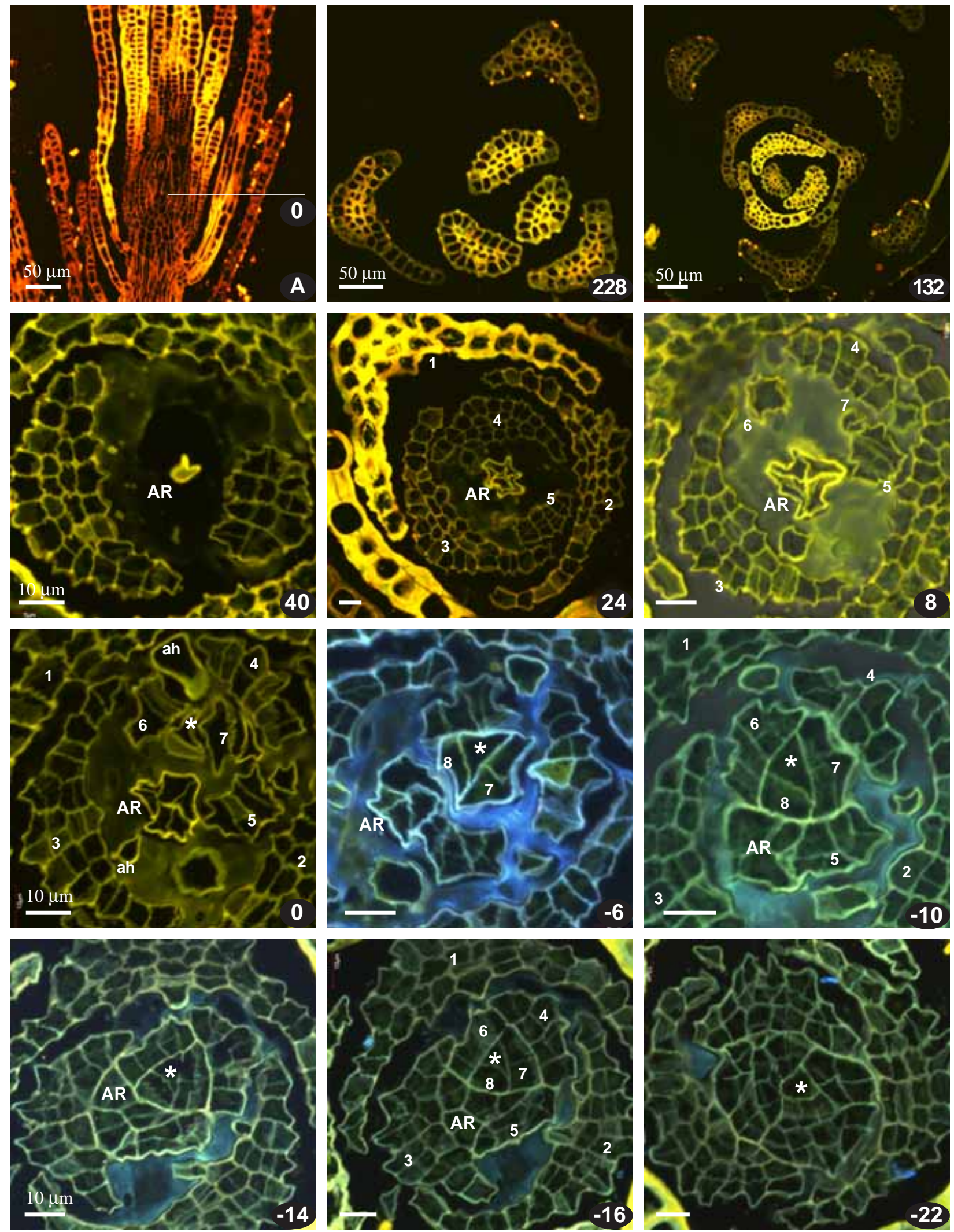

Fig. 9. Andreaeobryum macrosporum, female shoot (LSCM): longitudinal (A) and transverse sections, where values indicate the distance in $\mu \mathrm{m}$ from the apical cell (denoted as 0 in longitudinal section A). Note that unistratose lamina in younger leaves quickly transforms to multistratose. Archegonium (AR) is developed in a lateral position to apical cell (*); numbers on photo indicate a number of leaf conventionally (regarding available leaves at the level of stem apical cell). Axillary hairs (ah) are irregular in shape; it seems that slimy blur at apical cell level is caused by their contents (cf. Fig. 7). 

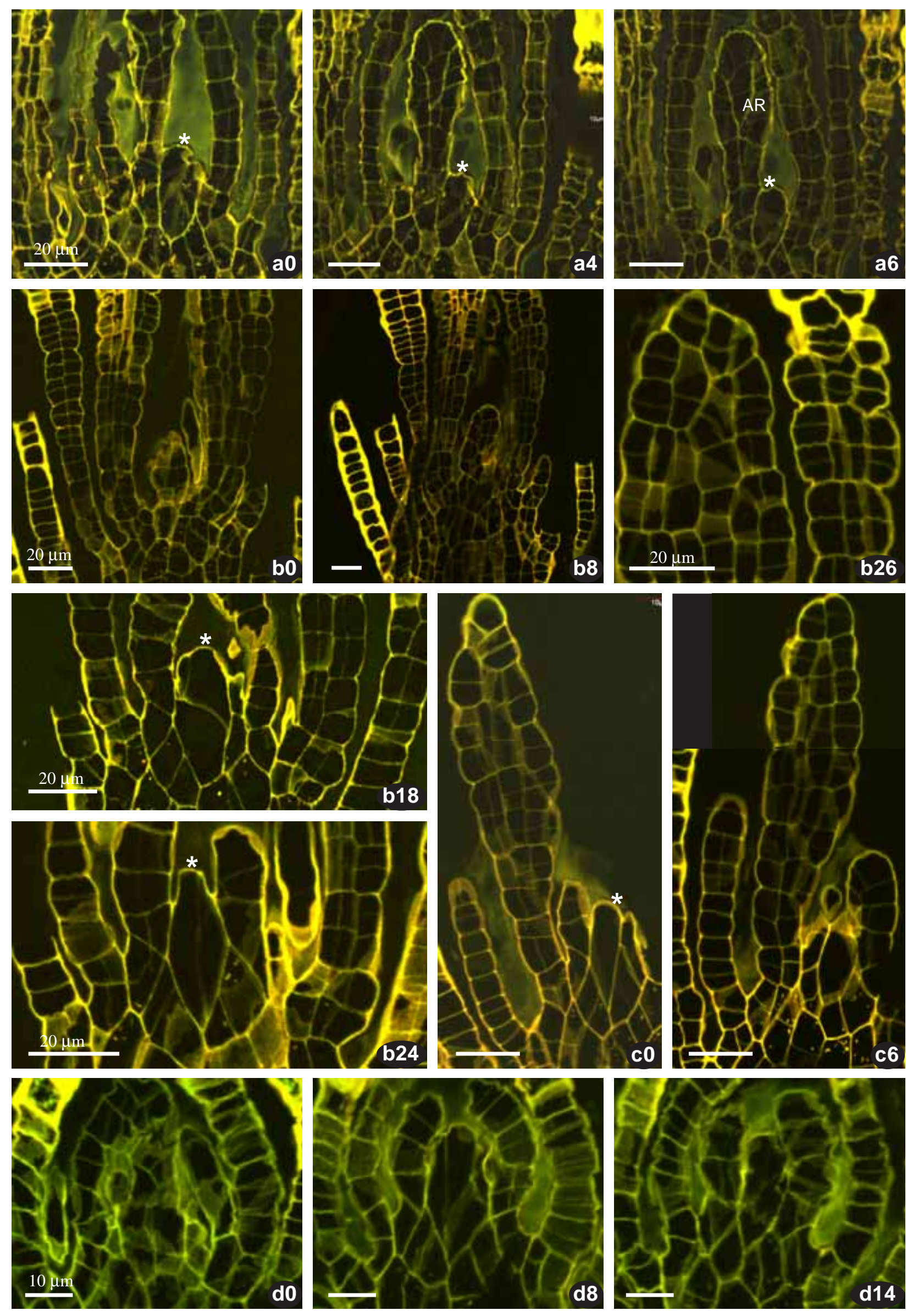
Some axillary hairs are composed of more than two cells (Fig. 7I), and in these cases the basal cell is apparently divided, producing up to five basal cells that form a uniseriate stalk. In extreme, the beaked axillary hair may sit on the top of a small leaf. The latter case was nicely illustrated by Murray (1988). In Siberian plants, we saw rather a hyaline apical leaf cell, with a beak-like knob (Fig. 13A), however the leaves terminated with developed axillary hairs were not seen simply because of less observation comparatively with those done in American specimens.

Young axillary hairs, obviously prior to mucilage release (Fig. 7C), have an inflated round beak, covered by another outer cover. Their position close to the stem apical cell assures that this type comprises the youngest, only recently developed axillary hairs. Within the middle part of its apical cell, a complicated heterogeneity (likely due to numerous vacuoles) is seen (Fig. 7C).

After the release of their mucilage, axillary hairs have their pores uncovered (Fig. 7B), or partly covered (Figs. 7J, L). A nipple-like tip above the cup-like cover (Fig. $7 \mathrm{~J}$, and see also Fig. 13F) is still not a fully understood structure. A possible interpretation could be that it is attached to the ovate body inside the axillary hair near its top, and thus keeps the pore cover in a position of ajar lid. Another analogy from moss structure could be a systilious operculum in mosses, which may potentially regulate spore release by changing its relative position to urn depending on moisture.

It is still indefinite if the axillary hairs from the sterile parts of shoots are obtuse from the beginning and may be treated as underdeveloped, or, alternatively, they became closed after active period of functioning with an open apical pore, which later became invisible (Fig. 7G, 13H).

Sometimes axillary hairs in Andreaeobryum appear branched under light microscope, but additional examination reveals that in these cases just the protoplast falls off the apical cell wall, surprisingly retaining its shape (Fig. 7E).

In the older part of shoots, the axillary hairs are displaced from the axil and are situated on leaf adaxially (Fig. 7F). This position is in agreement with the fact that axillary hairs remain attached to the leaf bases after their detachment (thus the study of axillary hairs on stem can succeed only in exceptional zones, for example in distal part of female shoots with archegonia).

Stem (Figs. 9- 10). Stem apical cell is relatively small and narrow, 30-35×13-16 $\mu \mathrm{m}$ (Fig. 10), and does not differ appreciably from that in other mosses.

Shape of the apical cell is approximately triangular in transverse section, but with unequal sides (Fig. 9). Hence the angle of the first division within the apical cell, as is seen in longisection, differs from $60^{\circ}$ to almost $0^{\circ}$ (i.e., being parallel to apical cell length). It seems, that such a plasticity allows development of leaves of quite different stature (Fig. 10).

Shortly below its apex, the stem is unusually narrow (Figs. 9, 14), which is difficult to assume from plants with leaves. Sections usually reveal its diameter being only $90-150 \mu \mathrm{m}$. The cortex is one-layered, and no central strand is seen under the observation in light microscope. However, the series of sections in Fig. 14 indicate a certain differentiation of cells in the center of the stem. The most conspicuous are the intracellular spaces, which have no fluorescence from berberin staining. It indicates the presence of cellulose-free space, which conducting capacity remains unclear.

Stem leaves (Figs. 5, 11, see also 9) in Andreaeobryum are in general dimorphous, including (1) orbicular small leaves (Figs. 5L-N) and larger lanceolate leaves (Figs. 5H$\mathrm{K}$ ) on 'normally' foliate stems (Fig. 6G). One shoot usually has one leaf type, although many julaceous shoots transform to 'normally' foliate ones distally (Figs. 3D, 4D, 6F).

Subterminal innovations in their proximal parts have leaves of one type, either orbicular or lanceolate, retaining the leaf uniformity further up to a considerable distance (Figs. 6G).

Orbicular leaves have fully unistratose lamina, originated through the divisions of bifacial apical cell in a way common for almost all mosses.

Lanceolate leaves differ from orbicular ones since early development. They become multistratose due to oblique divisions of leaf apical cell. Figs. 11E-H show two young leaves from different sides, where leaf \#2 appears already bistratose at the level of the leaf uppermost cells.

Fig. 10 (previous page). Andreaeobryum macrosporum (LSCM), four series of longitudinal sections through stem apical cells. Series $\mathrm{a}, \mathrm{b}$ and $\mathrm{c}$ were done in female shoots (with values indicating distance in $\mu \mathrm{m}$ from the the sections denoted as 0 ); series $\mathrm{d}$ is from julaceous shoot with small orbicular leaves. Series 'a' shows young archegonium (AR) next to the apical cell (*), while the latter remains functional. Series ' $b$ ' and 'c' show primary leaves near the stem apical cell. It is not clear if some young leaf-like structures (e.g., 'leaf' in front of apical cell in 'b0' and 'b8') is not a young archegonium. Andreaeobryum macrosporum (LSCM), longitudinal sections of julaceous shoot with small orbicular leaves. Some divisions in apical cell (in '8') are almost longitudinal (compare with Fig. 9-b24).

Fig. 11 (next page). Andreaeobryum macrosporum, young leaves near sterile shoot apex (A,C-J: LSCM, B, K-L: LM [K: Shiff staining]). A-D: one group of leaves, showing bulgings in distal cells; note that leaves \#2 and \#6 are obviously narrower at base than above (cf. with Figs. I-J). E-H: another group of leaves from different views, showing that the apical leaf cell is rather trifacial, not bifacial, forming multistratose leaf lamina since the beginning; leaf \#3 is multistratose as well; I-J: two leaves at opposite views; such rounded and concave leaves are the first in julaceous shoots. K: Cytoplasm staining illustrates the thick cell walls in distal parts of young leaves, although not from the earliest stage (compare with leaves \#4 and \#5 in the 'A-D' pictures). L: young leaves with rather apparent trifacial structure. 


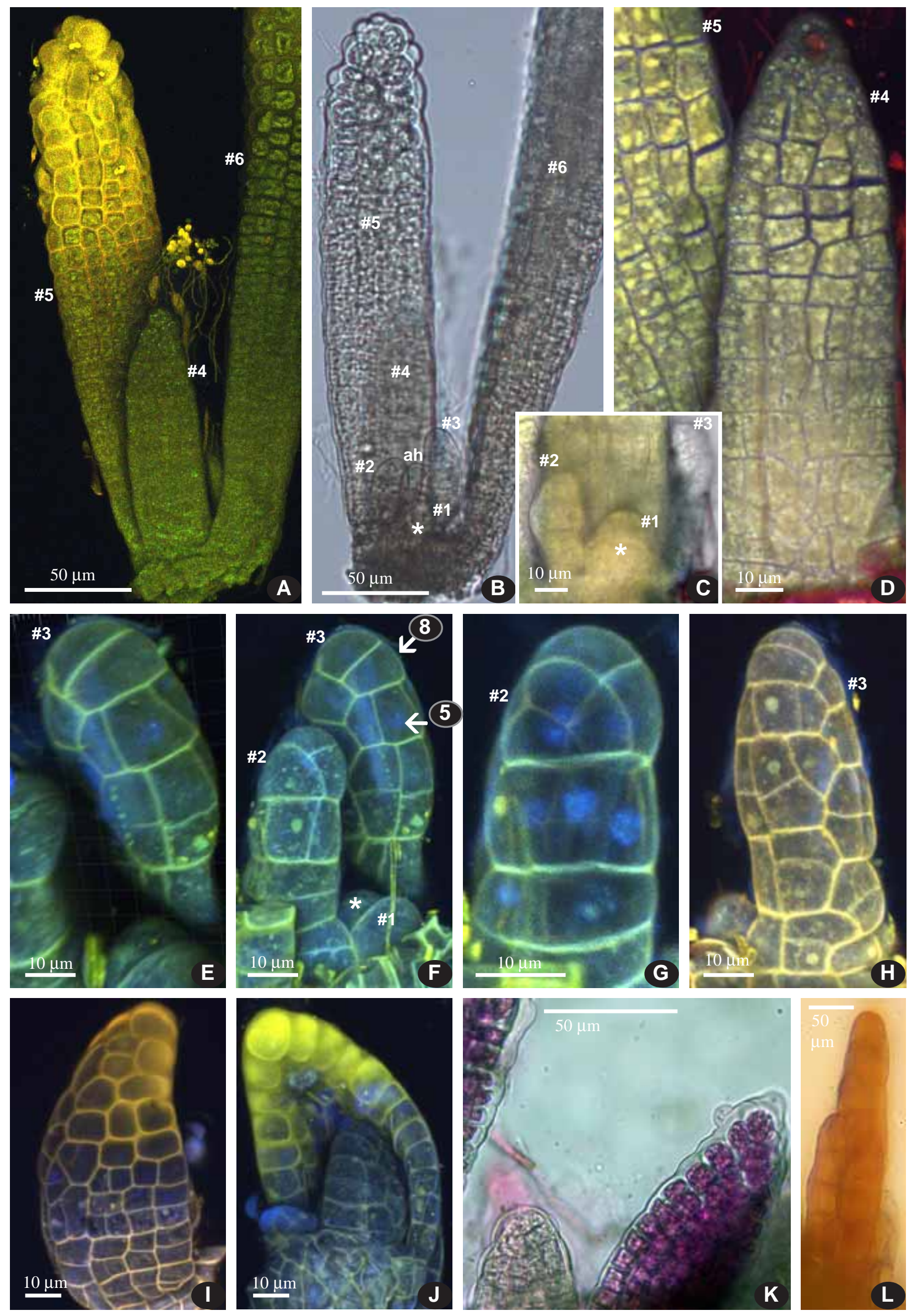



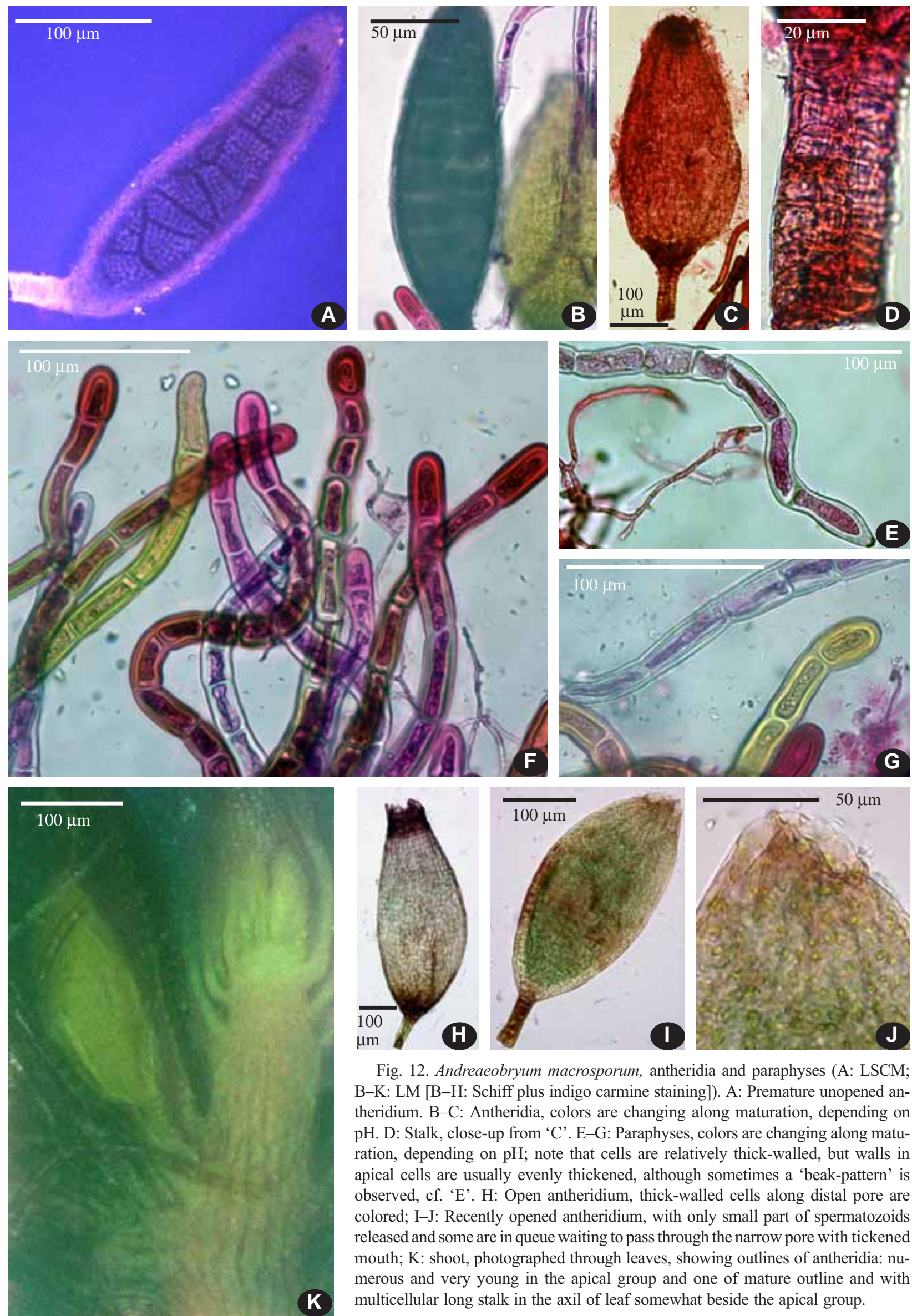

Fig. 12. Andreaeobryum macrosporum, antheridia and paraphyses (A: LSCM; B-K: LM [B-H: Schiff plus indigo carmine staining]). A: Premature unopened antheridium. B-C: Antheridia, colors are changing along maturation, depending on $\mathrm{pH}$. D: Stalk, close-up from ' $\mathrm{C}$ '. E-G: Paraphyses, colors are changing along maturation, depending on $\mathrm{pH}$; note that cells are relatively thick-walled, but walls in apical cells are usually evenly thickened, although sometimes a 'beak-pattern' is observed, cf. 'E'. H: Open antheridium, thick-walled cells along distal pore are colored; I-J: Recently opened antheridium, with only small part of spermatozoids released and some are in queue waiting to pass through the narrow pore with tickened mouth; K: shoot, photographed through leaves, showing outlines of antheridia: numerous and very young in the apical group and one of mature outline and with multicellular long stalk in the axil of leaf somewhat beside the apical group. 

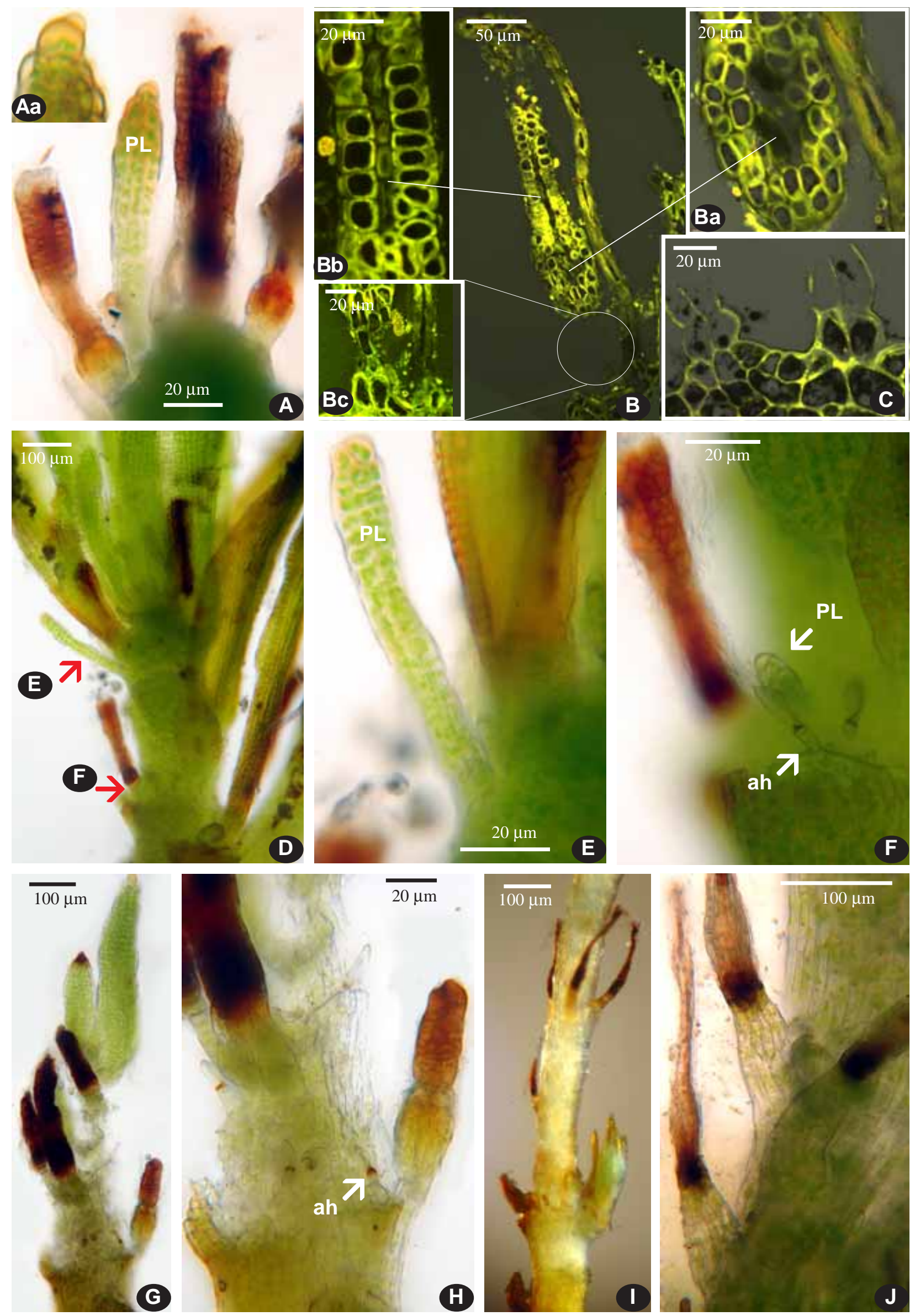
An areolation pattern characteristic for Andreaea, with unifacial apical cell (Kühn, 1874) was never observed in the leaf apical part of Andreaeobryum, where cell sectors are separated in left and right halves by zigzag line (Fig. 10-b26; 11F: leaf \#3). However, in the proximal part of leaf the rectangular direction of cell divisions becomes prevalent (Fig. 10, 11D), which may correspond to the basal cells of the leaf. Small leaves, similar to that shown in Fig. 11C, often have clavate shape, with obviously already 'multstratose' upper part (similar to that in leaves shown in Figs. 11E-H), and the narrow basal part. Fig. 11C does not show the structure of basal cells, but in longisections in Fig. 10, as well as in transverse section series in Fig. 9, there is a number of views showing that the more distal, the more multistratose the leaf is (e.g., \#5 in series in Fig. 9).

Laminal cells are originally quadrate closer to leaf margin and more rectangular in the middle, multistratose part of leaf, becoming round to ovate with age, occasionally oblate, unistratose except along the margin at base (Fig. 14). Older cells have incrassate cell walls, formed by cellulose and have strong berberin-fluorescence. An unusual character is great variation of cell wall thickness, as seen in transverse sections (cf. Fig. 14).

SEM observation without special preparation revealed a surprisingly regular papillosity on both surfaces of the Andreaeobryum leaf (Figs. 5O-P). After high vacuum collapse, many moss leaves display hollows upon cell lumen and ridged cell walls, but in case of Andreaeobryum, the situation is more complicated. Cell walls on the dorsal leaf surface became not solid, but beaded by chains of round papillae, and closer to the leaf margin 1-2-3 shallow papillae occur above the lumen as well. Ventral surface has even more puzzling pattern, which can be explained by a highly uneven internal structure of cell walls.

Crandall-Stotler \& Bozzola (1990) described the develpment and ultrastructure of leaf papillae in Andreaeobryum, finding in cell wall a microfibrillar network, a reminiscent of hygrophilic surface polysachharides. They conluded that such papillae are important for water absorption. The present observations on difference is leaf surface sculpture between dry (Fig. 50-P) and wet (Figs.9-11) state support this, indicating the malleability of the cell wall surface in Andreaeobryum.

\section{Perigonial leaves and Antheridia}

As perigonia are arranged on the stem at approximately equal distance, one may assume that they appear once a year, and, if this is true, the age of a plant in Fig. 6F can be evaluated as no less than 10 years old. Julaceous parts of plants may likely grow faster. The latter conclusion is based on the fact, that among the subterminal innovations, julaceous shoots are much more variable in length, while "normally' foliate shoots with elongate leaves have perigonia at not more than upper 2(-2.5) $\mathrm{mm}$.

Murray (1988) admitted that more than one generation of perigonia might originate on one shoot within one growing season, and this agrees with our observation of two nearby perigonia including still unopened antheridia at different stages of maturation. However, this is not a common case and considering that the habitat is covered by snow for no less than nine months a year, we can not also exclude a possibility that Andreaeobryum does not successfully produce gametangia every year.

Perigonial leaves are broadly ovate, ecostate (Figs. 4KL). Although the majority of antheridia are grouped in a quite compact male inflorescences, in many cases we observed solitary antheridia (usually bigger and more mature in axils of leaves next to perigonia. One of possible variants with additional antheridium beside the perigonium is shown in Fig. 12K. The photo is taken through the leaves, as their detaching may result in breakage and possible misplacement of antheridia. Paraphyses are abundant both within the perigonium and around solitary antheridia.

Antheridia are long-stalked (Figs. 12A, D, I), similar in this respect to those of Andreaea, Sphagnum (especially of Eosphagnum and Ambuchanania), and hepatics. Elongate and acute when premature (Fig. 12A), they become ovate later, at time of gamete release. Schiff staining provides color differentiation of antheridia (Figs. 12B-D) and paraphyses (Figs. 12E-G) along with their maturation.

Spermatozoids are released through a small pore surrounded by a massive thick-walled cells (Figs. 12I-J). It seems that the discharging of antheridia is fairly gradual, at least in the beginning of the male gamete liberation. In mosses and liverworts, as far as we know, the antheridium opening is explosive. After a more or less complete spermatozoid release, the pore region is strongly colored by Schiff staining, indicating thicker walls, as compared with the rest of antheridium walls. Although opened antheridia

Fig. 13 (previous page). Andreaeobryum macrosporum (A, D-H: LM; B-C: LSCM) and Andreaea rupestris (I-J: LM), archegonia, showing their variable apical and subapical positions in Andreaeobryum and location at base of pseudopodium in Andreaea. Note pedestaled archegonia both in Andreaeobryum and in Andreaea. Note primary leaves (PL) in between large leaves and beside archegonia, and numerous axillary hairs (ah). The leaf apical cell in 'Aa' has a terminal papillae.

Fig. 14 (next page). Andreaeobryum macrosporum (A-D: LM, the rest: LSCM), showing position of archegonia side by side with primary leaves. ' $\mathrm{D}$ ' is pedestaled leaf, or a 'half-leaf, half archegonium', likely started developing as archegonium, but after fertilization of neigboring archegonium started developing lamina. The series '10'-'160' shows one leaf axil with one archegonium (AR) and three primary leaves PL1-3, shown in selected pictures). Note that the pedestal of archegonium has leaf-like structure: see '126'. Note that the central part of stem has enormously extensive intracellular space, putatively having conduction capacity. 


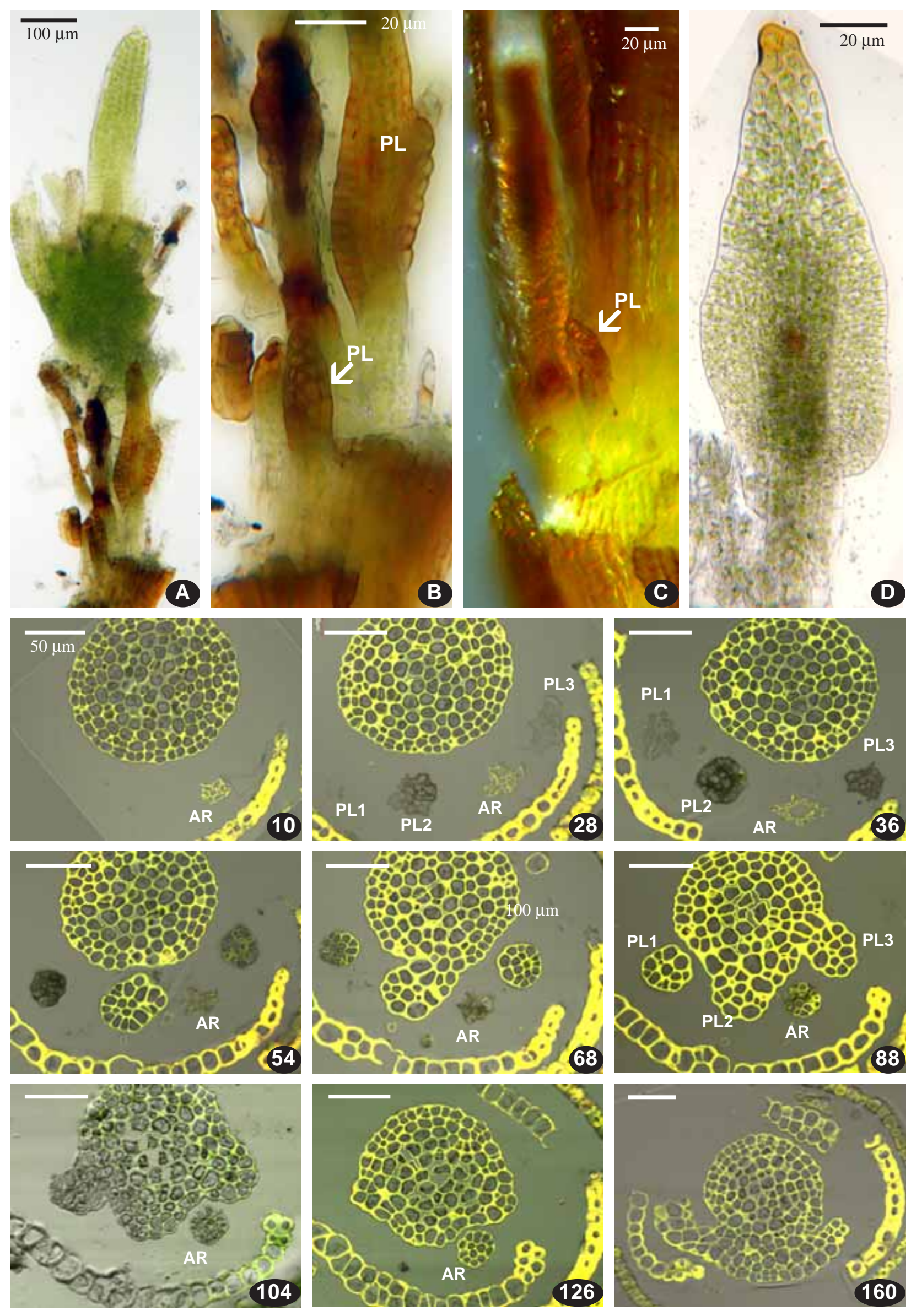


in Andreaeobryum are often darker near their apical pore, the darker area includes mostly 1-2 cell rows.

Perichaetial leaves, Primary leaves and Archegonia

Murray (1988) considered both perichaetial leaves and primary leaves as a very unusual structures of Andreaeobryum, and the present observation revealed even more their peculiar characters. Primary leaves were defined as a much smaller leaves, located in leaf axils by one or two, and considered as having a very unusual structure. In Siberian plants, the upper part of female plants is full of such structures, and interpretation is not easy.

Archegonia appear terminal, although in every series of sections we never saw them in a really terminal position. When an archegonium is formed, stem apical cell continues its growth (Fig. 9). Thus, archegonia appear to be spread along the distal part of stem and sometimes up to $10 \mathrm{~mm}$ below stem apex.

It is still unclear if archegonium may substitute for the apical cell and thus stop stem growth, but the parallel observation of Schuster (1971) would be suggestive. In discussing the anacrogynous species of Haplomitrium, where numerous archegonia also develop and are displaced downwards the stem along with the growth, Schuster admitted, that after production of a sufficient number of archegonia, the plant may 'exhaust itself' and finally produce terminal archegonium. However, real evidence for this was not obtained.

Murray (1988) underlined a probably unique case of anacrogyny in mosses in Andreaeobryum, which is similar to hepatics. Fig. 9 shows a series of transverse sections, where the subapical archegonium is cut to its base, showing that it originates from one merophyte cell, developing into archegonium and leaf. This explains numerous cases where a small leaf is sitting side by side with archegonium (Figs. 13F; 14B-C), in our specimens mostly to the right from it.

This ability to transform one part of leaf into archegonium explains as well the series shown in the Fig. 14. This series illustrates four elements in leaf axil arranged in one row, although deriving from stem at an interval of $70-80 \mu \mathrm{m}$. Three of them are interpreted as leaves due to homogeneous cells in transverse section, while one with tubulose distal part can not be anything but the archegonium, as it has an empty cylindrical part in its centre. It still has a homogeneous structure at base, as it is seen in transverse section, interpreted as an archegoium pedestal (its length of ca. $50 \mu \mathrm{m}$ agrees with the pedestal length in other archegonia in Figs. 13 and Fig. 14). As a whole, this four-element structure, occupying about $1 / 3$ of the stem circumference, has maximal similarity with the tetra-filamentose leaf of Takakia, where one of lobes is substituted by an archegonium.

Organ substitution in mosses is usually not considered, as there is no evidence. However, in another bryophyte lineage, the Hepaticae, the substitution of a halfleaf with the branch is a fact, basic for any discussion on numerous types of branching (Crandall-Stotler, 1972).
In Haplomitrium half of a leaf can be transformed into an antheridium (Schuster, 1966b). Among mosses, in addition to Andreaeobryum, the ability for substitution occurs in Takakia, where one lobe of bilobate leaf may be substituted by lateral branch.

The ability to metamorphose also explains perichaetial leaves of strange shape. Most of them look similar to archegonia, but with the attached piece of leaf lamina, often just on one side. It is noteworthy, that such structures are especially common at base of epigonium, where they more likely represent unsuccessful archegonia, which, instead of implementation of their main function, started to transform into a leaf.

An interpretation of the position of small primary leaves as axillary may be erroneous, at least partly, due to very dense spiral arrangement of leaves and their derivative organs near the female stem apex.

Archegonia are pedestaled in Andreaeobryum (Fig. 13), as well as in Andreaea (Fig. 13I-J). The central part of the pedestal looks colored, hampering localization of egg-cell. However, all searches resulted in finding eggcell at $30-50 \mu \mathrm{m}$ above the stem, shortly above the constriction well seen in most archegonia.

The putative young archegonia (assumed as such by the position near stem apex and by comparison with archegonia at later stages of development) have paired round cells at base (Fig. 13C), divided by constriction from cells above. It seems likely that these pairs further develop into pedestals. The latter have a structure quite similar to that seen in leaves in transverse sections (series in Fig. 14).

Placenta and epigonium (Figs. 15-21).

After fertilization, young capsule starts to develop, and at first stages, up to $0.5-0.7 \mathrm{~mm}$ long, a spindleshaped sporophyte remains totally embedded in the mucilage-like medium formed within the epigonium. Epigonium at this stage is filled with the semi-decomposed cells, separated from the inner surface of its wall (subsequently calyptra) and also surrounded by vaginular tissues. Hence, within the epigonium, an extraordinary broad space is formed; it surrounds the sporophyte to the end of the foot and even beyond it; this space is continuous and will be called below 'placental space', although it is not restricted to the zone of contact of foot with vaginula, but stretches between the whole young sporophyte body and epigonium inner wall.

The maceration of cells from epigonium wall is observed in all directions. The solvent-like medium penetrates ahead of the foot first to the volume of archegonium pedestal, and then in the vaginula, building a space for the growing foot. In the series in Fig. 23, the modification of gametophytic cells is seen at the distance of no less than $20 \mu \mathrm{m}$ from the haustorial cells. The modification includes shrinking of cytoplasm volume, deposition of soft polysaccharide compounds along the cell walls, and maceration of cells, so that they appear to be separated by intracellular space, also rich in polysaccharide compounds. 

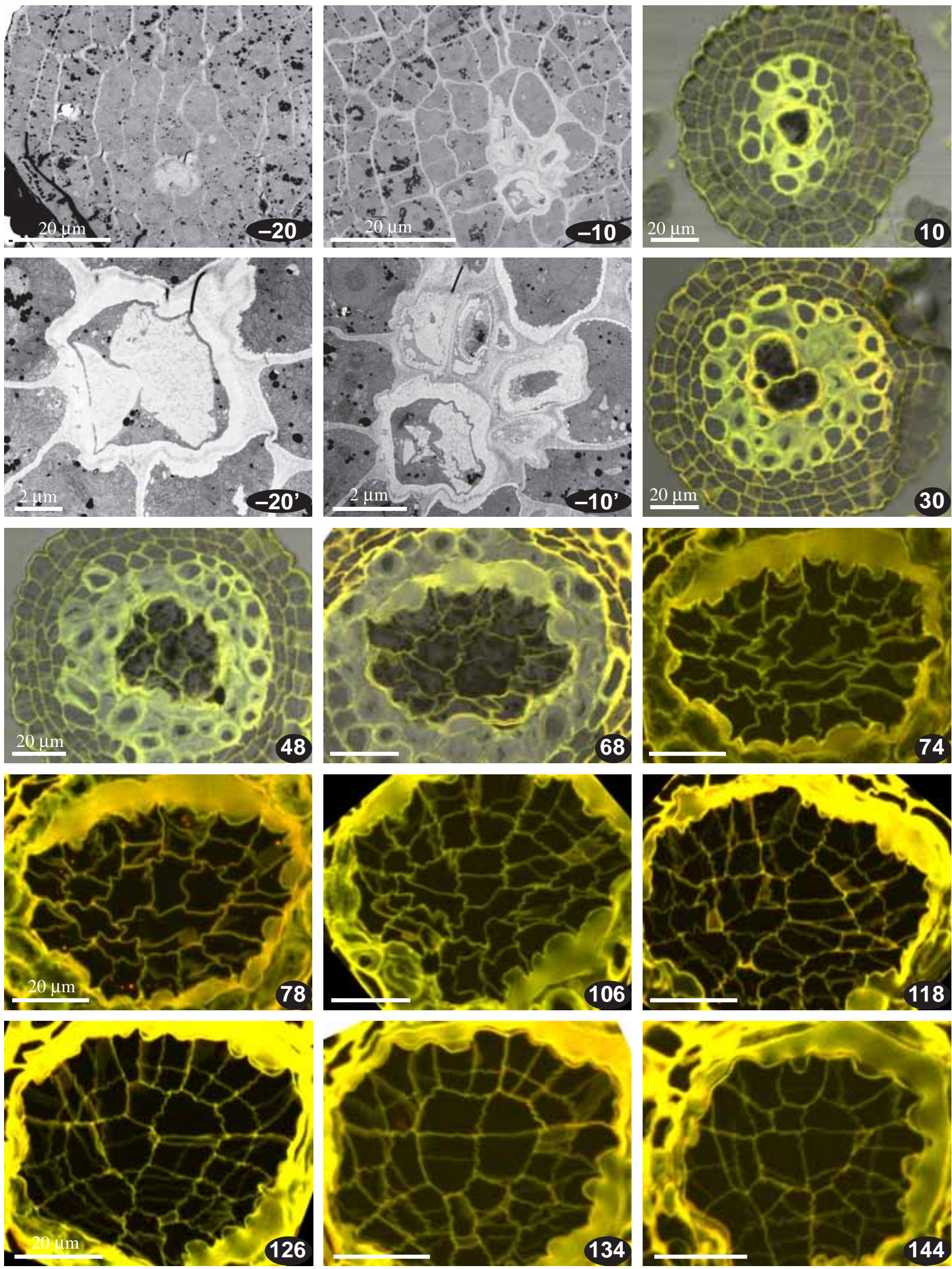

Fig. 15. Andreaeobryum macrosporum, transverse sections of young sporophyte of ca. $200 \mu \mathrm{m}$ long, still embedded in epigonium ( -10 and -20 and their close ups: TEM; 10-144: LSCM; the values indicate the distance from foot tip, $\mu \mathrm{m}$ ). Note strongly modified gametophyte cells near sporophyte foot, being rich in starch (white), but without ingrowths. Note that at the level of capsule (126-144) sporophyte cells retain the arrangement of fundamental cross, whereas at the level of foot (68-78) sporophyte outline and cells are rather flattened (cf. with Fig. 23). 

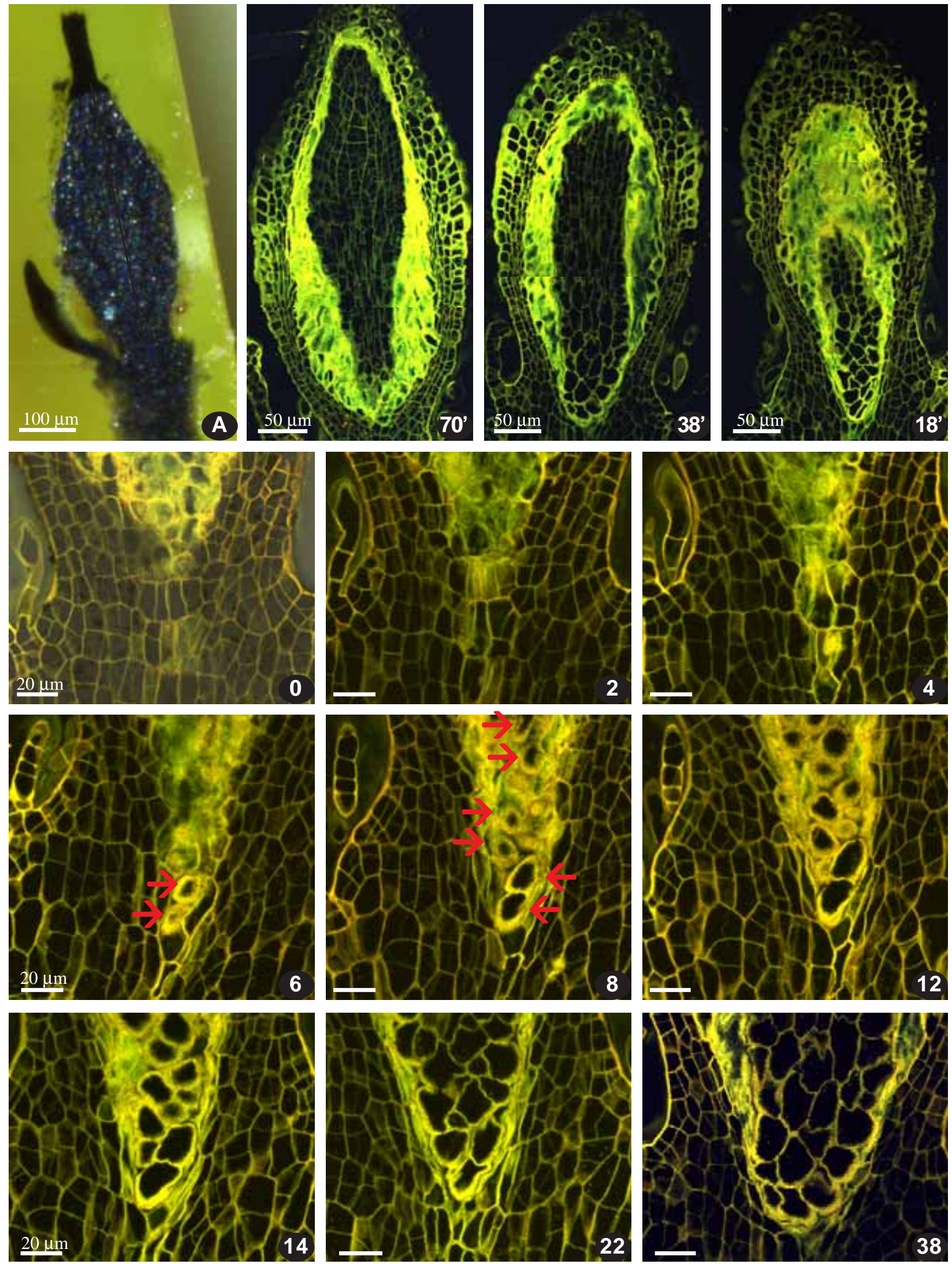

Fig. 16. Andreaeobryum macrosporum (LSCM), longitudinal sections through epigonium (total view in 'A') with young sporophyte of ca. $400 \mu \mathrm{m}$ long inside (the latter is somewhat oblique). Values indicate the distance (in $\mu \mathrm{m}$ ) from the section denoted as 0 , where placental space with mucilage medium appeared in this series of sections. Sporophyte cells appear after $6 \mu \mathrm{m}$ (arrowed in ' 6 ' and ' 8 '). Gametophytic cells adjoining to the foot are narrow. Foot cells have brighter fluorescence due to cell wall ingrowths (cf. Fig. 17 and 18A-D). Note a three-celled beaked axillary hair in '0'-'2'-'4', followed by five-celled axillary hair in '6'-'8'-'12'. 

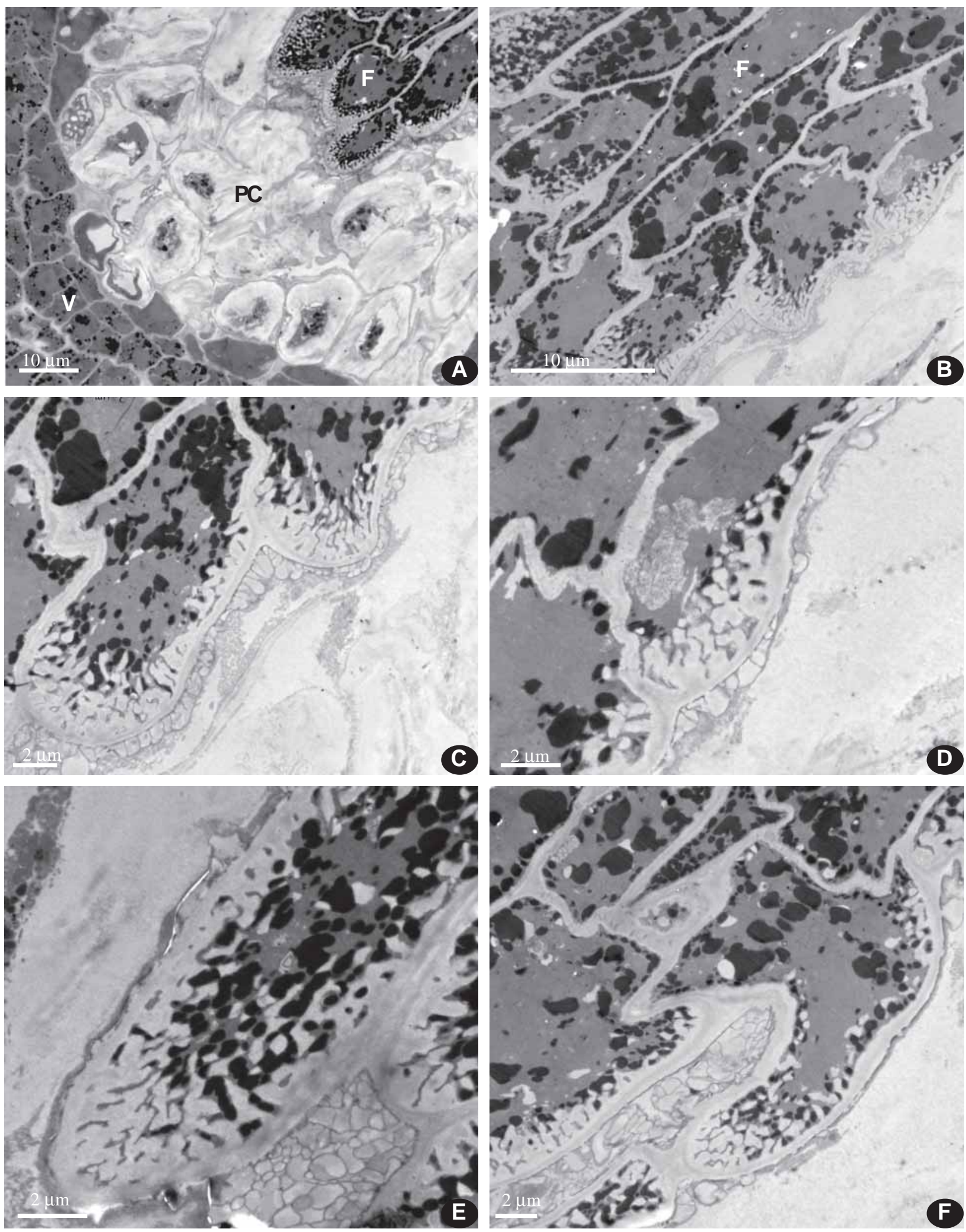

Fig. 17. Andreaeobryum macrosporum (TEM), longitudinal section through foot of young sporophyte embedded in epigonium and shown in Fig. 16-70' (note that this section is somewhat beside from the tip of the foot). Note numerous ingrowths of cell walls in the outer cell layer of foot and occasionally in some inner cells in ' $\mathrm{B}$ ', and labyrinths on the foot surface faced to the placental space (cf. also Figs. 18A-D). A: Foot is separated from gametophyte tissue by expanded placental spaced filled by macerated and partly decomposed gametophytic cells; note that walls of gametophytic cells faced to placental space lack any ingrowth, but they are partly irregular in shape, obviously experienced some degradation toward complete maceration. B-D: Foot periphery showing protruding of its surface cells. E-F: foot surface showing some 'fjords' of placental space, filled with possible starch-like material. 

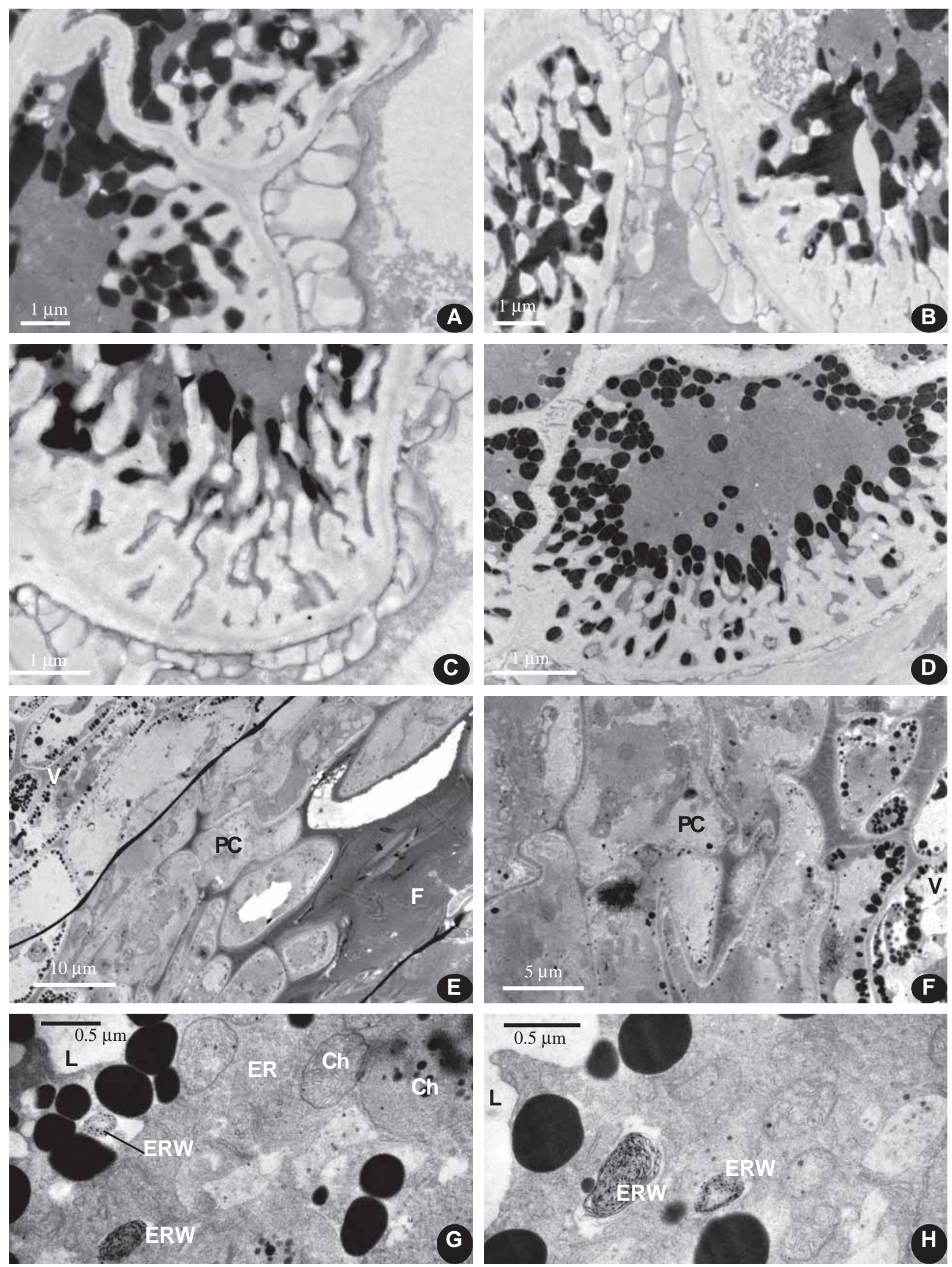

Fig. 18. Andreaeobryum macrosporum (TEM). A-D: Longitudinal section through the foot of young (cf. Fig. 16-70) sporophyte embedded in epigonium. E-F: Cells of vaginula (V) and placental space (PC) adjoining to the foot (F) of mature sporophyte (cf. Fig. 23), showing cells of placental space with strongly 'softened cell walls', with numerous invaginations. G-H: Ultrastructure of surface foot cells (from specimens in Fig. 19): among chloroplasts (Ch) and endoplasmatic reticulum (ER), the ER whorls occur, presumably implementing autofagous function, utilizing membranes along with the labyrinth $(\mathrm{L})$ expansion. 

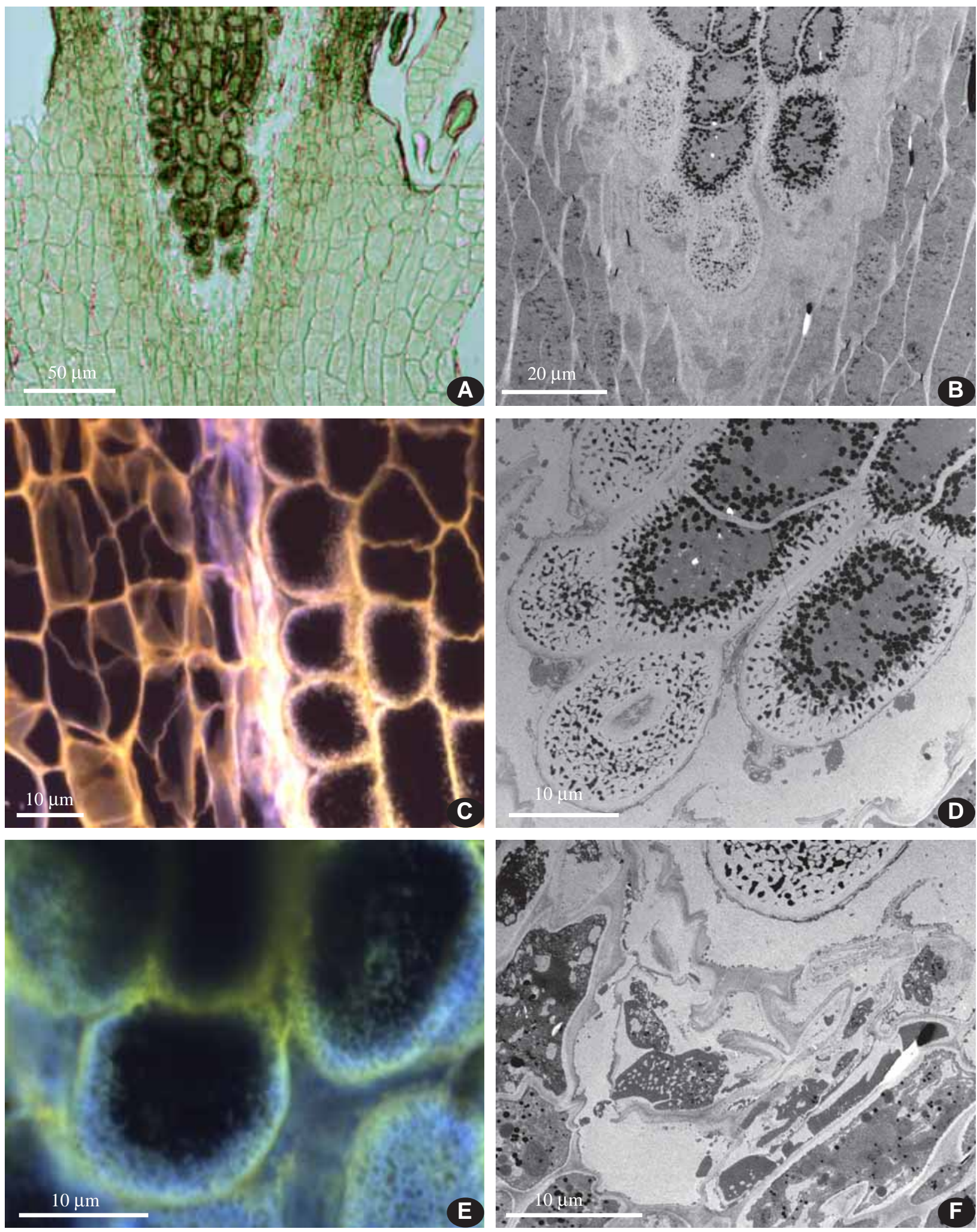

Fig. 19. Andreaeobryum macrosporum (A: LM, B, D, F: TEM; C, E: LSCM). Longitudinal section of foot of sporophyte at the stage approximately the same as in Fig. 16. A: Change of color of still intact gametophyte cells around the foot and decomposed cells in placental space. B, D, F: details of 'A', showing lack of ingrowths in gametophytic cells, strongly developed labyrinths in outermost foot cells and strongly modified cells within placental space. ' $\mathrm{D}$ ' shows 'fjords' within the foot, filled with the putatively starch 'outer labyrinths', as in Figs. 17E-F. C \& E are LSCM picutes from $2 \mu \mathrm{m}$ section, shown in 'A': labyrinths looks spongy, being especially well-developed near haustorium, but quite abundant in the second surface layer of cells in the middle part of the foot; no ingrowth are seen in the closest gametophytic cells, and decomposed cell material in placental cells produces a strong fluorescence. 

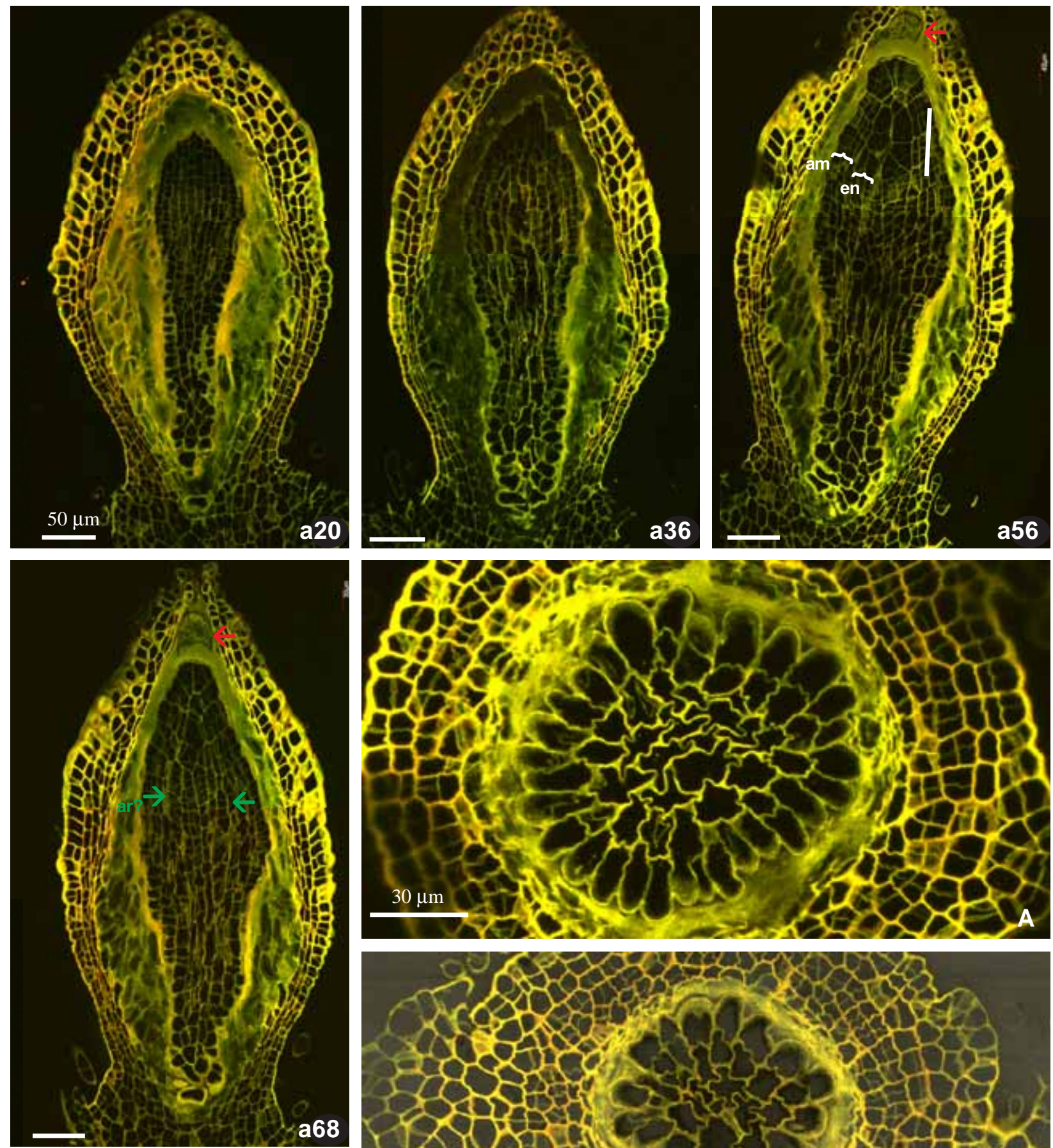

Fig. 20. Andreaeobryum macrosporum (LSCM). a20-a68: longitudinal sections through epigonium with young sporophyte. Series a20-a68 shows the stage somewhat later than in Fig. 16 (sporophyte is $135 \mu \mathrm{m}$

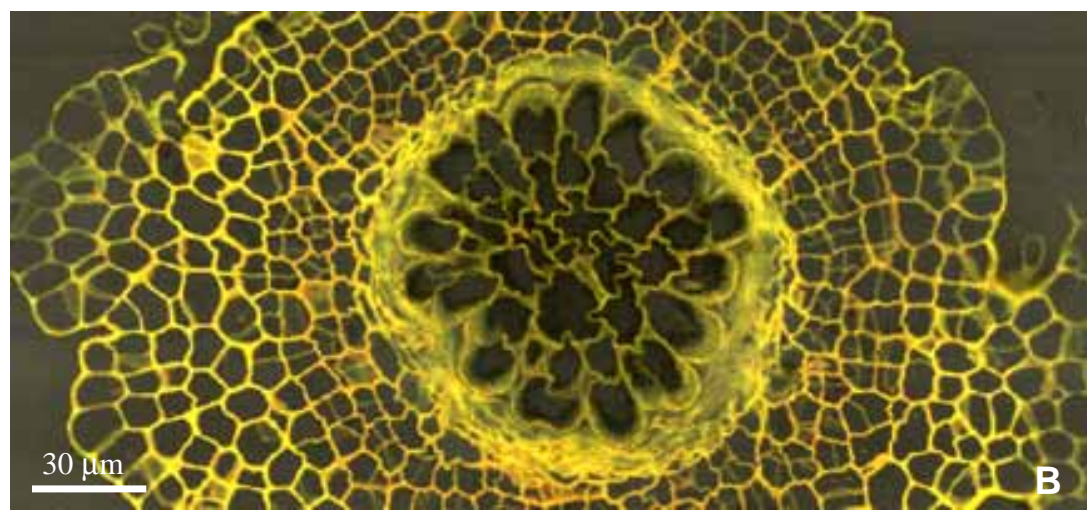

in diameter vs. $100 \mu \mathrm{m}$ in Fig. 16), while A and B show still later stage (sporophyte ca. $200 \mu \mathrm{m}$ ). Values indicate the distance (in $\mu \mathrm{m}$ ) from the first section denoted as 0 (not shown), where placental space with mucilage medium around sporophyte appears discernible. Foot is composed of a larger number of cells and conducting tissue at the seta level is better developed. Haustorial part is more blunt and looks not so efficient in penetration in gametophytic tissue, as compared with that in Fig. 16. A solid mass of cells with small dark bodies near the base of archegonium neck likely represent spermatozoids, which were late for fertilization (red arrows in '56' and ' 68 '). '20' shows pre-exothecial cells in the upper third of sporophyte. '56' is a section through the middle of the sporophyte, showing well differentiated amphithecium (am) and endothecium (en) in the upper part of sporopyte. A bar on the right indicates the level, represented in a series of transverse sections in Fig. 26. Potential archesporial tissue ('ar?' in '68') is still almost undifferentiated. A-B: transverse sections, showing lobate foot, with outer cells with extensive ingrowths. The section ' $\mathrm{B}$ ' is closer to foot base, so leaf, archegonia and axillary hairs sections at various levels are seen. 

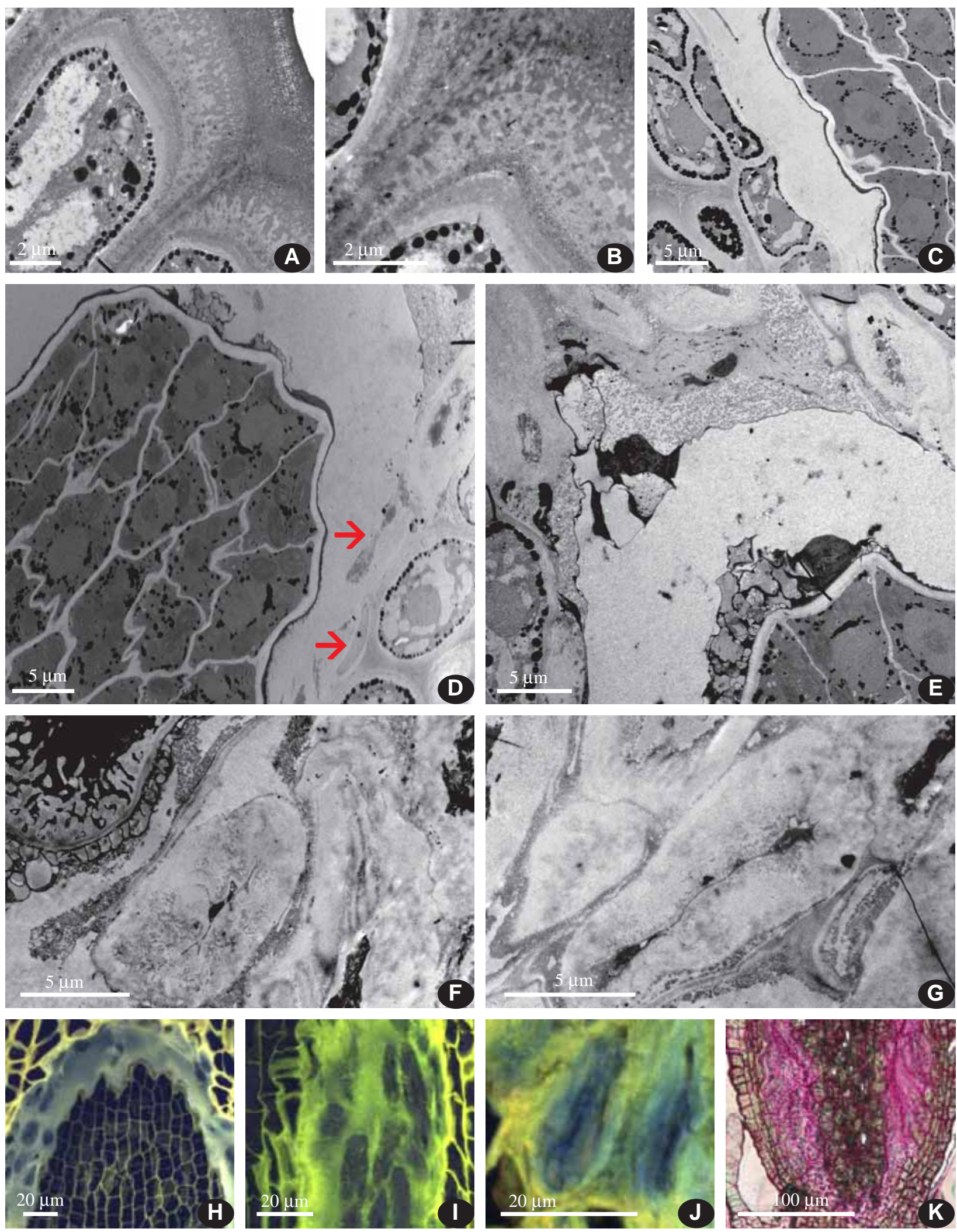

Fig. 21. Andreaeobryum macrosporum (A-G: TEM; H-J: LSCM; K: LM; specimen from Fig. 16). Longitudinal sections through epigonium with young sporophyte inside, showing epigonium wall and some its inner decomposing cells filling the placental space. A-B: Walls of outer epigonium cells, showing complex multistratose polysaccharide structure. C-D: Space between sporophyte and inner surface of epigonium wall, showing long cells (arrowed) floating in a medium, likely a sort of mucilage. E: Epigonium inner wall faced sporophyte apex: this is a place with especially strongly decomposed inner cells of epigonium wall. F-G: Cells in placental space near the sporophyte apex ('H') and closer to foot (' $\mathrm{I}-\mathrm{K}$ '): strongly incrassate cell wall fills almost the whole volume of the cell. H-K: Autofluorescence and Schiff staining indicate a high content of polysaccharide in the placental space. 

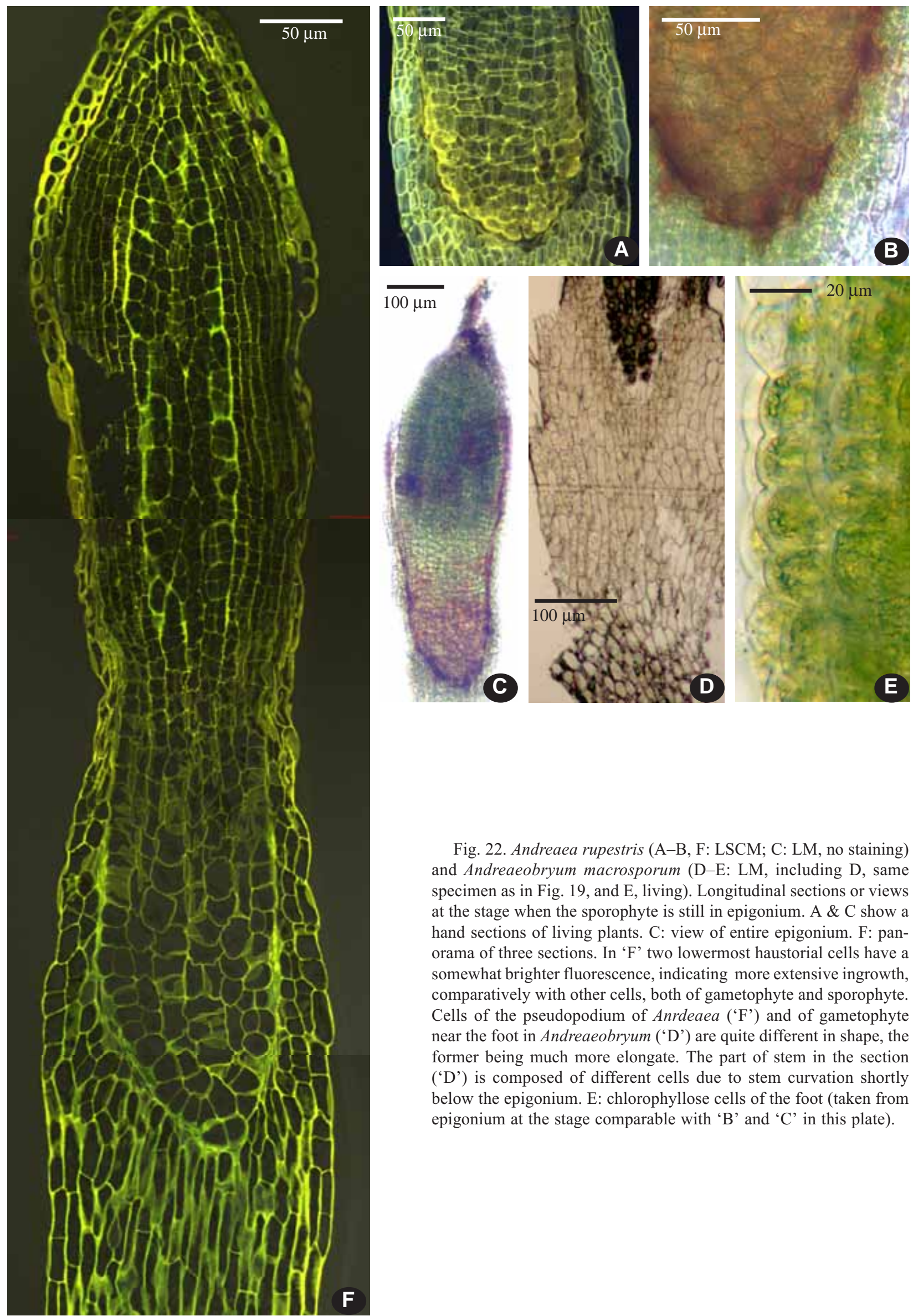

Fig. 22. Andreaea rupestris (A-B, F: LSCM; C: LM, no staining) and Andreaeobryum macrosporum (D-E: LM, including D, same specimen as in Fig. 19, and E, living). Longitudinal sections or views at the stage when the sporophyte is still in epigonium. A \& $\mathrm{C}$ show a hand sections of living plants. C: view of entire epigonium. F: panorama of three sections. In ' $F$ ' two lowermost haustorial cells have a somewhat brighter fluorescence, indicating more extensive ingrowth, comparatively with other cells, both of gametophyte and sporophyte. Cells of the pseudopodium of Anrdeaea ('F') and of gametophyte near the foot in Andreaeobryum ('D') are quite different in shape, the former being much more elongate. The part of stem in the section ('D') is composed of different cells due to stem curvation shortly below the epigonium. E: chlorophyllose cells of the foot (taken from epigonium at the stage comparable with ' $\mathrm{B}$ ' and ' $\mathrm{C}$ ' in this plate). 
The foot is covered by inflated cells from its tip and sometimes by elongate and occasionally multicellular outgrowths (Figs. 17E-F), as in Diphyscium (Ligrone et $a l ., 1993)$. Transfer cells are well developed in sporophyte part in 2-3 layers. Moreover, the outer surface of the foot bears labyrinth-like structures facing the placental space (Figs. 18A-D). At the same time, cells of the gametophyte have no ingrowths, excepting small zone of immediate contact with the haustorial cells, where the surrounded vaginular cells have fluorescence similar to that of placental space. No inward projections were observed in the gametophyte cells (Fig. 19C). At the same time, the vaginular cells immediately adjoining the placental space near the foot tip have a number of differences: they are strongly elongate (Fig. 16, series) and differentiated in color (Fig. 19A).

Placenta in the developed capsule has a narrower placental space, cells from the sporophyte are dark, with poorly discernible inner structure, and labyrinths are seen only in some cells. Gametophytic cells closer to placental space (Figs. 18E-F) have softer cell walls, although organelles and nuclei look normally developed, at least in some of them. Further cells with numerous osmiophilic globules and with non-modified cell-walls follow.

Placental space material is obviously of a gametophytic origin. The especially strong decomposition of gametophyte cells is seen around the haustorial cell (Figs. 19D, F) and near the sporophyte apex, which is the same place as the base of the archegonium neck (Fig. 21E).

The contents of the surface foot cells includes in addition to labyrinths, endoplasmatic reticulum, and numerous small chloroplasts, also a whorl-shaped structure, similar to ER-phagous ER-whorls in yeast (Schuck et al., 2014). This is likely not just a superficial similarity, as the foot cells have to utilize their membranes, along with the cell wall ingrowth progress. Inner cells of the epigonium wall also contribute to the placental space with macerated cells: innermost of them appear transitional in their structure to 'cells' of the placental space (Fig. 21D).

Two extensive overviews of the moss placenta structure did not illustrate Andreaeobryum, although they mentioned that it has one layer of transfer cells with ingrowths in the sporophyte, and no modification of the cell wall in gametophyte (Frey et al., 2001; Ligrone \& Gambarella, 1988). In general, the placenta at the stage of mature capsule has such a structure, although the mucilage content of the placental space allows only poor impregnation of this zone, resulting in crumbling of the cuttings.

Placental structure is similar to Andreaea, Takakia and Polytrichaceae by the absence of cell wall ingrowths in gametophytic cells.

The extensive mucilage-filled placental space seems to be unique in Andreaeobryum. As this character relates to multistratose calyptra, it can be an additional evidence for the relationship of Andreaeobryum with Takakia.

\section{Seta}

Murray (1988) noted the flattened seta in Andreaeobryum. Her explanation referred to the thin-walled cells filling almost the whole seta and easily collapsing upon drying.

Although all this is true, we found that the seta of Andreaeobryum is dorsiventral in transverse sections (series in Fig. 15) since the whole sporophyte is only $200 \mu \mathrm{m}$ long, and far from any drying and living in comfortable liquid volume inside the mother plant body. The cause for such asymmetry can be in unequal halves of the endothecium since its original differentiation (discussed below under 'Columella').

One almost mature sporophyte, including foot, seta and part of capsule, was transversally sectioned (Figs. 23-24), confirming the dorsiventral structure of seta. In the seta middle, the medullar thin walled central part is broader than high in $20-30 \%$, and cell orientation and outlines are also keeping orientation of the overall dorsiventrality (e.g., in 23-1020).

Seta of Andreaeobryum is described as having no central strand. The present observation confirms this statement, if consider central strand as a narrow structure formed by cells with narrow lumen. Such structure is definitely absent in Andreaeobryum, but there is another one. It starts at about $0.35-0.4 \mathrm{~mm}$ from the foot tip, e.g., at the level where the foot is transforming into seta (surface cells losing their ingrowth structure and outer foot cells loose their regular, radially orientated arrangement, cf. Fig. 23-258). At first, the conducting tissue of seta looks like a central group of cells with open lumens and somewhat thicker cell walls (Fig. 23-462). They differ in contrast from the surrounding cells, being full of highly refractive material, perhaps starch.

Shortly after its differentiation, this 'central strand' has already obtained a diameter about a half that of the seta (Fig. 23-540) and soon reaches the diameter of the whole seta excepting two or three outer cell layers. Cells of the latter are still rich in starch, while thin- but firmwalled cells in the middle look as numerous guide cells, confirming conductive capacity of the 'central strand', which can be probably assumed as such despite a rather unusual structure.

Immediately below the capsule base, the seta layers receive additional stratification: the innermost cells become still larger, forming a lighter central part, and still further, at the level of columella base, cell structure is even more complicated: some cells become narrower, being flattened in tangental direction, while central cells are larger and conspicuously firm-walled (Fig. 23-1430).

In dry state, the seta is strongly flattened and usually also conspicuously twisted.

The development of conducting tissues in young sporophyte proceeds at a rather early stage. Two series of sections in Figs. 16 and 20 indicate much longer cells at 

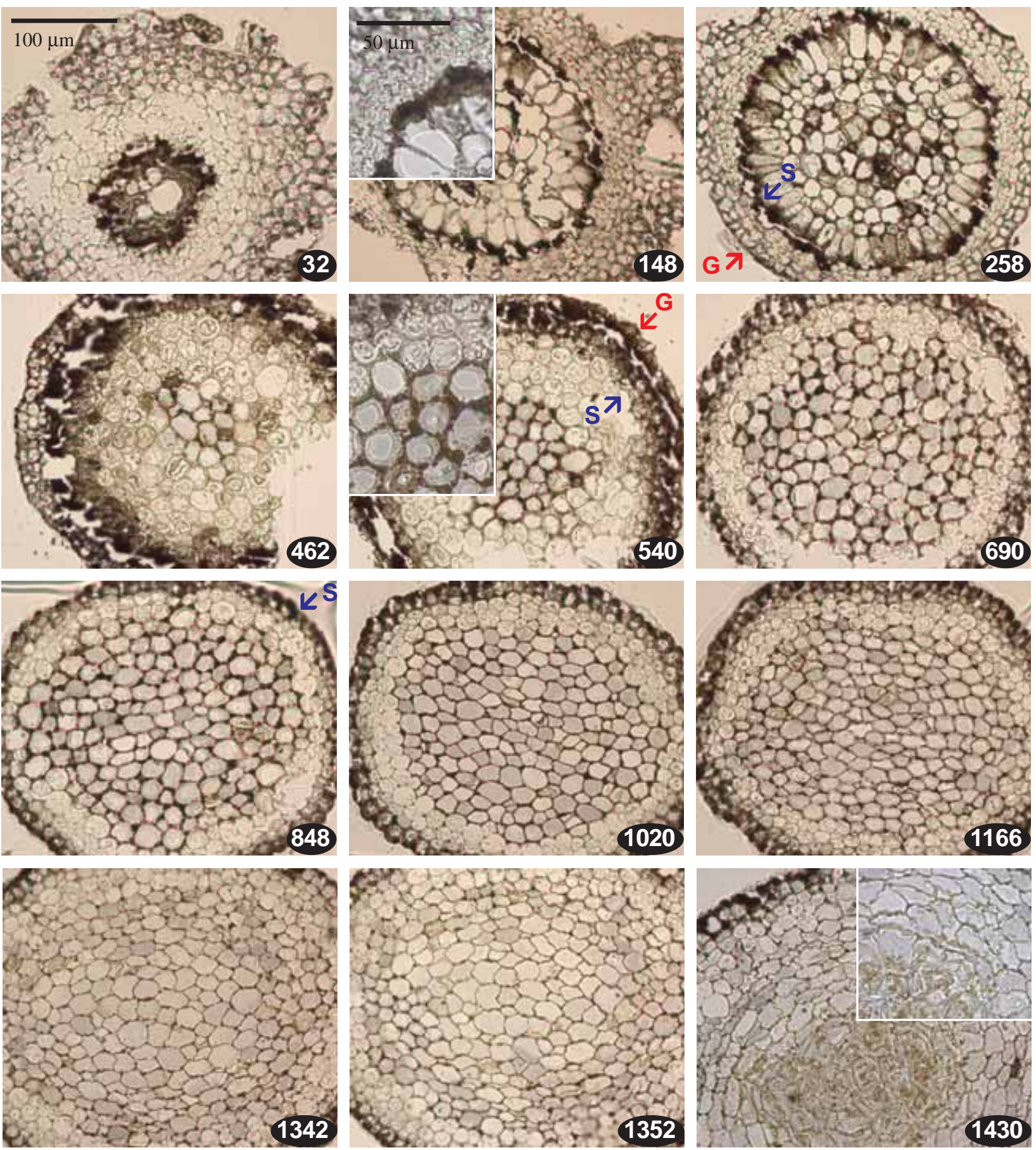

Fig. 23. Andreaeobryum macrosporum (LM). Transverse sections through almost mature, but still not opened capsule and its seta and foot, corresponding to stage shown in longitudinal section in Figs. 30A. Values indicate the distance (in $\mu \mathrm{m}$ ) from the end of foot. Foot is composed of dark cells, and cells of placental space are collapsed and destroyed (they occur up to '690' section, the last one where gametophyte tissue is shown). In the middle part of foot (shown in section '258') outer cells of the foot are radially elongate, considerably differing from the heterogeneous cells of the central part of foot. From ' 462 ' a central strand appears in the seta: it is composed by larger cells with thicker walls, contrastingly different from surrounding cells, which are filled with some material (apparently starch-like), while cells of this central strand look empty. At ' 540 ' the central strand is broadened up to half of foot diameter and then it fills almost the whole width of the foot, leaving only 2-3 layers of the starch-like tissue surrounding the foot. The vaginula extends to ' 690 ', although alreary at '540' gametophytic tissue (' $G$ ', arrowed) surrounding the foot/ seta (' $\mathrm{S}$ ', arrowed) is thin, eroded and hardy functional. At the level of middle part of seta, from ' 848 ' to ' 1342 ', the seta becomes somewhat flattened in the ratio of its own width to height, as well as cells in its central part become transversely elongate. Closer to capsule base, at '1352', cells in the centre are changing to larger; in '1430' rectangular cells surrounding the base of columella are corresponding to the amphithecium (cf. with '1450'-'1506' in Fig. 24). 

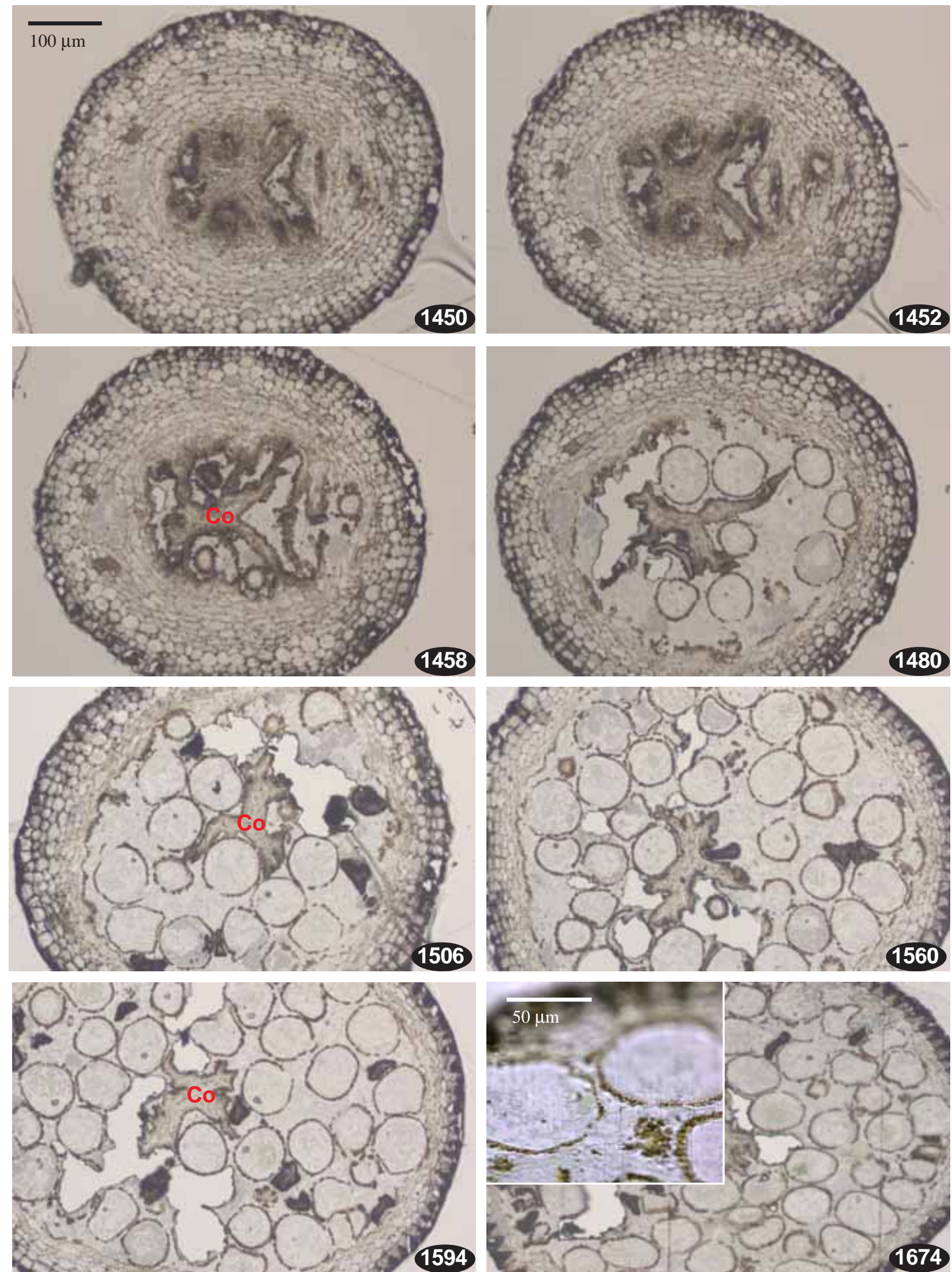

Fig. 24 (continued from series in Fig. 23). Transverse sections, where values indicate the distance (in $\mu \mathrm{m}$ ) from the end of foot. Spore chamber starts in this series from ' 1450 ', at first as several (roughly four) compartments between the branches of cross-like columella (Co). Note a strong resorption of cells of the urn wall: in capsule middle, at ' 1674 ' urn wall consists of three cell layers inside the exothecium, while in capsule bottom, at '1480'it has up to 13 layers (cf. also with Fig. 27). 

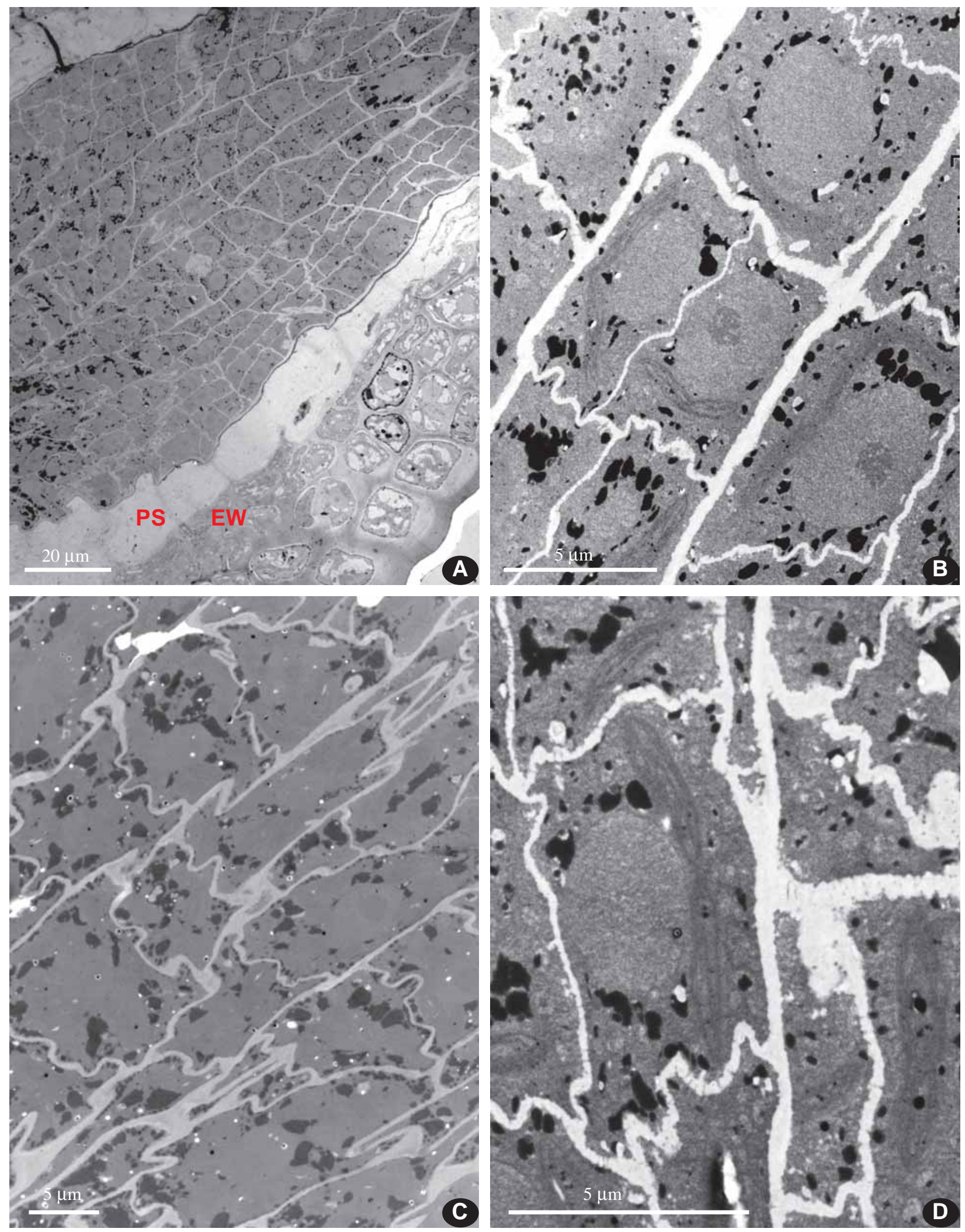

Fig. 25. Andreaeobryum macrosporum (TEM, same specimen as in Fig. 16-70). Longitudinal sections at stage when the sporophyte is still in epigonium. A: Central part of the capsule, placental space (PS) and epigonium wall (EW), showing the complicated structure of the latter (cf. Fig. 21). B: Cells of the 'pre-columella' in upper part of sporophyte in 'A'; nuclei and chloroplasts fill most of the cell volume; transverse cells walls are strongly flexuose and porose. C: Lower part of the capsule at the level of transtition to seta, cell walls are strongly flexuose. D: Cells from the lower part of the capsule, showing strongly flexuose cell walls; plasmodesmata are seen in both transverse and longitudinal cell walls. 

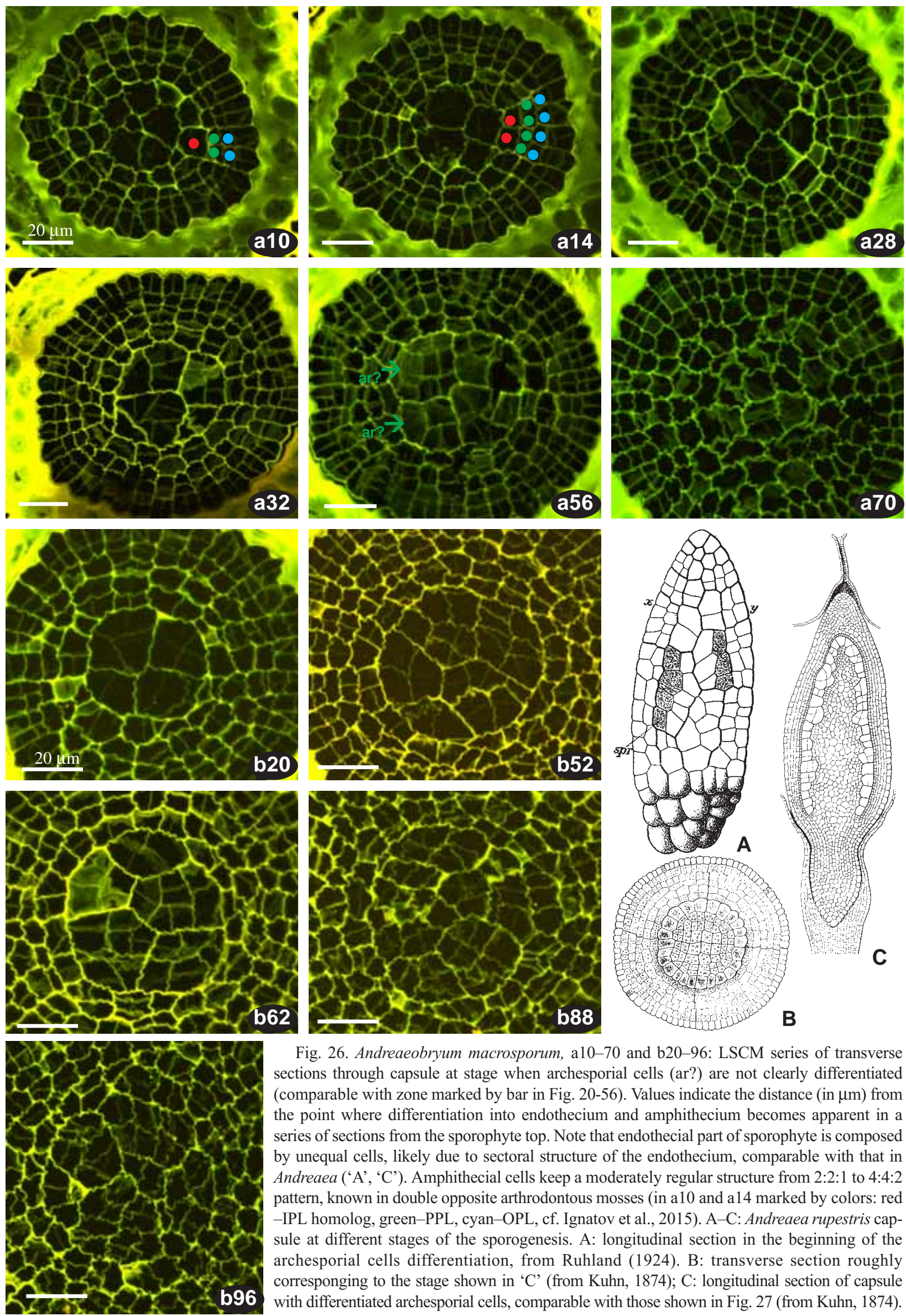

Fig. 26. Andreaeobryum macrosporum, a10-70 and b20-96: LSCM series of transverse sections through capsule at stage when archesporial cells (ar?) are not clearly differentiated (comparable with zone marked by bar in Fig. 20-56). Values indicate the distance (in $\mu \mathrm{m}$ ) from the point where differentiation into endothecium and amphithecium becomes apparent in a series of sections from the sporophyte top. Note that endothecial part of sporophyte is composed by unequal cells, likely due to sectoral structure of the endothecium, comparable with that in Andreaea ('A', 'C'). Amphithecial cells keep a moderately regular structure from 2:2:1 to 4:4:2 pattern, known in double opposite arthrodontous mosses (in a10 and a14 marked by colors: red -IPL homolog, green-PPL, cyan-OPL, cf. Ignatov et al., 2015). A-C: Andreaea rupestris capsule at different stages of the sporogenesis. A: longitudinal section in the beginning of the archesporial cells differentiation, from Ruhland (1924). B: transverse section roughly corresponging to the stage shown in ' $\mathrm{C}$ ' (from Kuhn, 1874); C: longitudinal section of capsule with differentiated archesporial cells, comparable with those shown in Fig. 27 (from Kuhn, 1874). 
the level of seta, although the latter one represents only a slightly older stage (sporophyte is $135 \mu \mathrm{m}$ in diameter vs. $100 \mu \mathrm{m}$ in Fig. 16). Attempts to obtain a longitudinal section of seta at the stage about the same as in Figs. 23 and 24 were not successful, as cells of the central part of the seta were crumpling in a way similar to that of the foot-vaginula junction in Fig. 23-462.

\section{Archesporium and Columella}

Endothecial cells in the central part of the young capsule are surrounded by 3-4-layered amphithecial cells (Figs. 25 and 26). The former reach the top of the future spore chamber, being at the same time arranged in a series of alternating sectors, similar to that in Andreaea (Figs. 26B-C).

Archesporial cells were found in the series of longisections at the stage of well-developed capsule, while at the earlier stages they were rather indistinct (cf. series in Figs. 20 and 26). However, similarity of the pattern with clearly expressed sectored structure of endothecium (cf. Figs. 27 and 26C) indicates a great overall similarity between Andreaeobryum and Andreaea.

Archesporial cells are at the beginning of their differentiation in Figs. 20 and 26. They are only slightly differentiated in shape, thus their status is deduced from their position in the outermost layer of endothecium.

A rather regular structure of cell arrangement in amphithecium is notable (Fig. 26), corresponding to the peristomal formulae 4:2:2. characteristic for mosses of both nematodontous (Polytrichum, Tetraphis) and double-opposite arthrodontous (Encalyptaceae) groups.

Some sections demonstrate a somewhat later differentiation in the distal endothecial segments (Fig. 20) as compared with the proximal ones, and this pattern well corresponds with sporogenesis in Andreaea (Fig. 26B), where the archesporial differentiation in the upper part of the capsule is also late.

Developed archesporial cells are situated in the peripheral parts of endothecial sectors, as the central part is building the columella.

The columella in Andreaeobryum has been described as stellate in cross section (Murray, 1988). Our observations are fully congruent with this, showing details of columella structure (Figs. 24, 27, 28, 30), and especially of projections, joining at places with the outer spore sac, reminiscent of Takakia (Renzaglia et al., 1997).

Although the columella connections to the outer spore sac are fairly irregular, it seems possible to recognize in general the four-pointed star (Fig. 24), which corresponds to some sections of the capsule.

The most surprising observation on the sporophyte development is that the columella on its top is connected to the outer spore sac. The latter case is observed in some views, but the complete series of sections (Figs. 27-28) demonstrates that the Andreaeobryum case is not at all like that of Sphagnum. Hence the description of Andreaeobryum columella as overarched by sporogeneous tis- sue has to be challenged. Having connection to the outer spore sac, columella in Andreaeobryum has some similarity with Bryalean mosses, albeit in the latter columella is much broader above.

At the same time, a great similarity with Andreaea is also seen, in which archesporium is also sectored (cf. Figs. 26 and 29). Thin membranaceous connectives are poorly developed in Andreaea (Fig. 29C), hence Andreaea was also considered as a moss with columella not reaching the top of the spore chamber. However, the uppermost sectors of the the endothecium in Andreaea can be late in development, thus the 'young columella + undifferentiated archesporial tissue' may join the top of spore chamber (Fig. 29C). Similar cases are shown in Fig. 29E, G, I: above the archesporial cells, there is a continuation formed by cells, which cannot be anything else but the 'young columella + undifferentiated archesporial tissue'.

\section{Spores}

Sporophytes with spore mother cells and early stages of sporogenesis were not found in available material. Spores in a still closed capsule are shown in Figs. 24 and 30 . They are of bright orange color when observed under stereomicroscope, however in transmitted light of the compound microscope their green chloroplasts are well seen. A number of abortive spores were seen in most of the studied capsules (Fig. 24, 30), although in some capsules they were almost absent. Abortive spores are darker in color in osmium-staining sections (Fig. 24), and have more intense color under upper light of halogen lamp (Fig. 30). Ultrastructurally they are variable, but with invariably present perine layer (Fig. 37). The flattened and angulose shape of abortive spores is likely a result of pressing within the spore mother cell wall during the maturation.

Spores have an uneven granulose surface, making the spore look rough, like a diseased skin, under the light microscope (Figs. 30-31, 33-34, 37-38). SEM observation of spores from herbarium material without additional preparation shows them often strongly collapsed. The granulose surface ruptures at places, and perfectly smooth layer underlaying the granulose layer becomes exposed (Fig. 32).

The spore wall structure of Siberian plants is shown in SEM (Fig. 32), TEM (Figs. 33-37) and LSCM photographs (Fig. 38), and LM of acetolyzed spores (Fig. 38: D-G).

The main part of spore wall is electron-translucent and not (Fig. 34A) or weakly (Fig. 35D) stratified to two or three layers slightly different in color in TEM images. Sometimes the innermost layer at the contact with osmiophilic drops is lighter (Fig. 34A), but this is far from often. LSCM fluorescence images illustrate a rather complex structure and gradual transitions from innermost layer (blue fluorescence) to outer part of cell wall that has yellow fluorescence of cellulose after berberine staining (Fig. 38A-D). Outside the homogeneous part of spore wall two granulose layers occur. The inner one comprises the electron-dark osmiophilic small granules, (0.01-) 

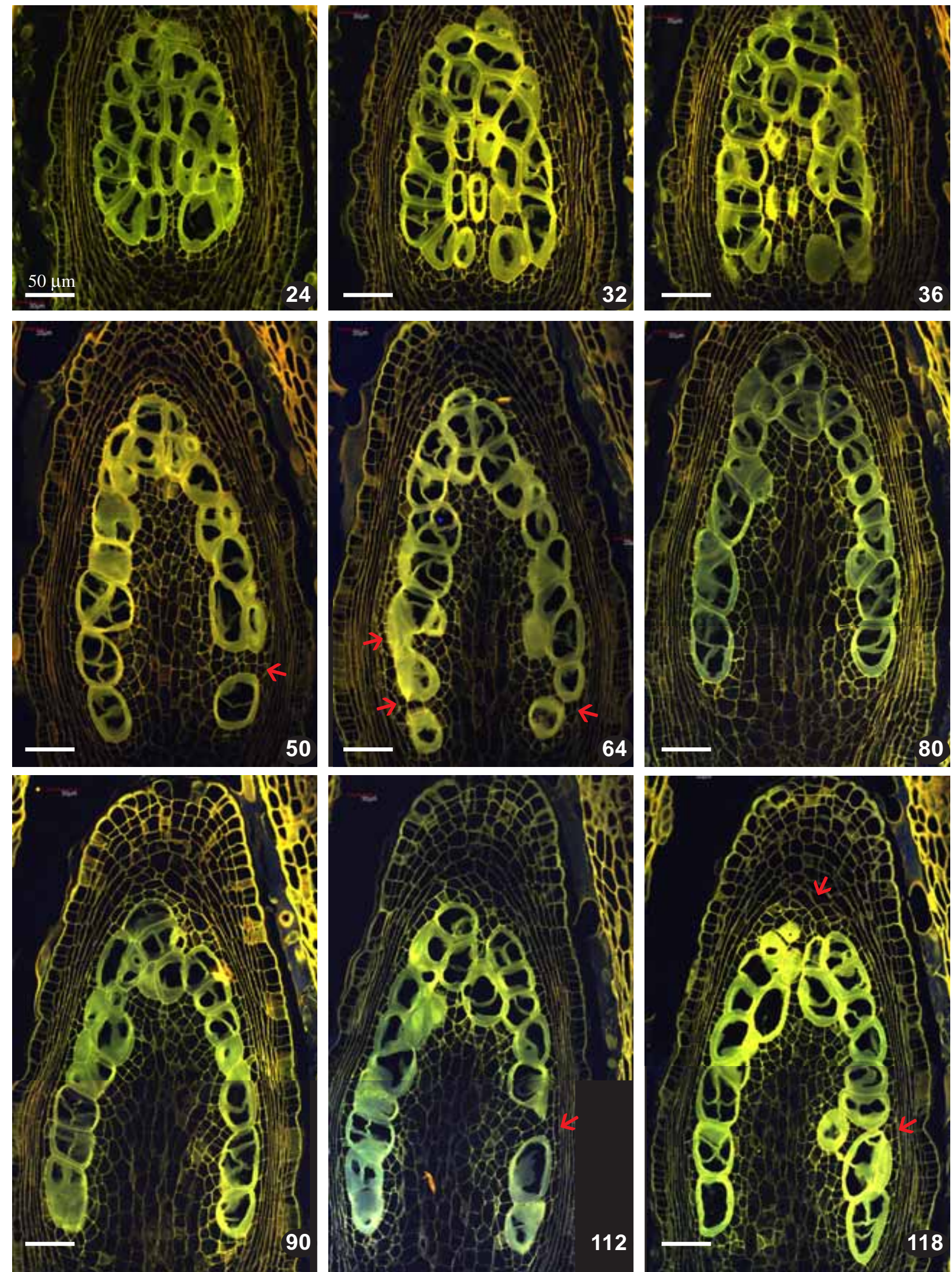

Fig. 27. Andreaeobryum macrosporum (LSCM), longitudinal sections of capsule at the stage of differentiation of archesporial cells (cf. also Fig. 28), showing discontinuous layer of archesporial cells and columella connectives with the spore sac in both lateral and apical parts of the capsule (arrowed). Values indicate the distance (in $\mu \mathrm{m}$ ) from the first section, denoted as 0 , where archesporial cells first appear among cells of the capsule wall (0 is not shown). 

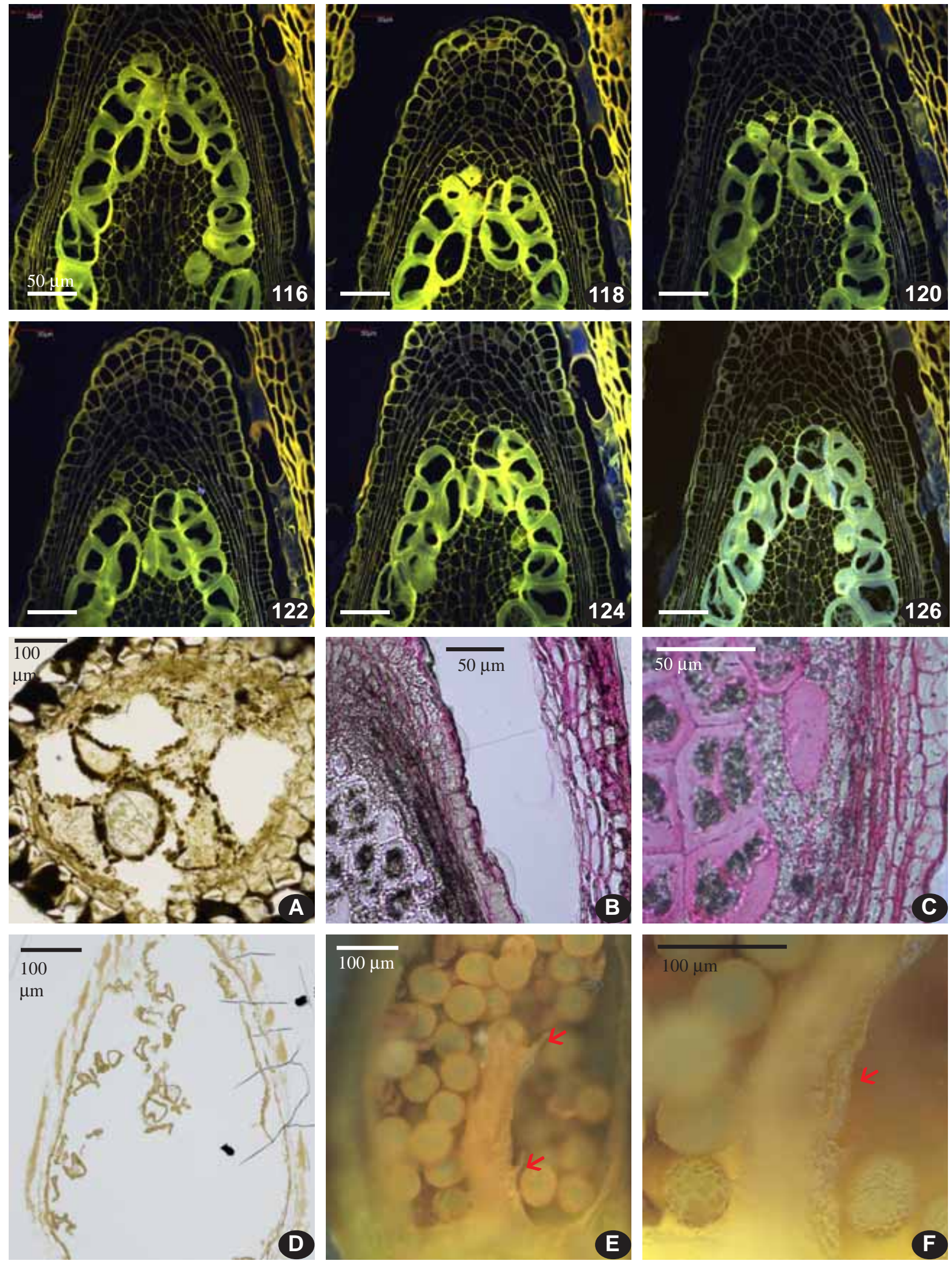

Fig. 28. Andreaeobryum macrosporum (116-126: LSCM, A-F: LM). 116-126: part of the series shown in Fig. 27, focusing on the uppermost part of the capsule, where the archesporium is not continuously overarching the columella. A: transverse section of mature capsule showing connectives from columella to the urn wall; B-C: Shiff staining indicating that capsule walls and archesporial cells are rich in hexoses. D: longisection of the capsule, showing part of columella (or a connective from columella to outer spore sac) attached to the urn near the top of spore chamber. E-F: Hand section of capsule, showing columella with membranaceous projections. 

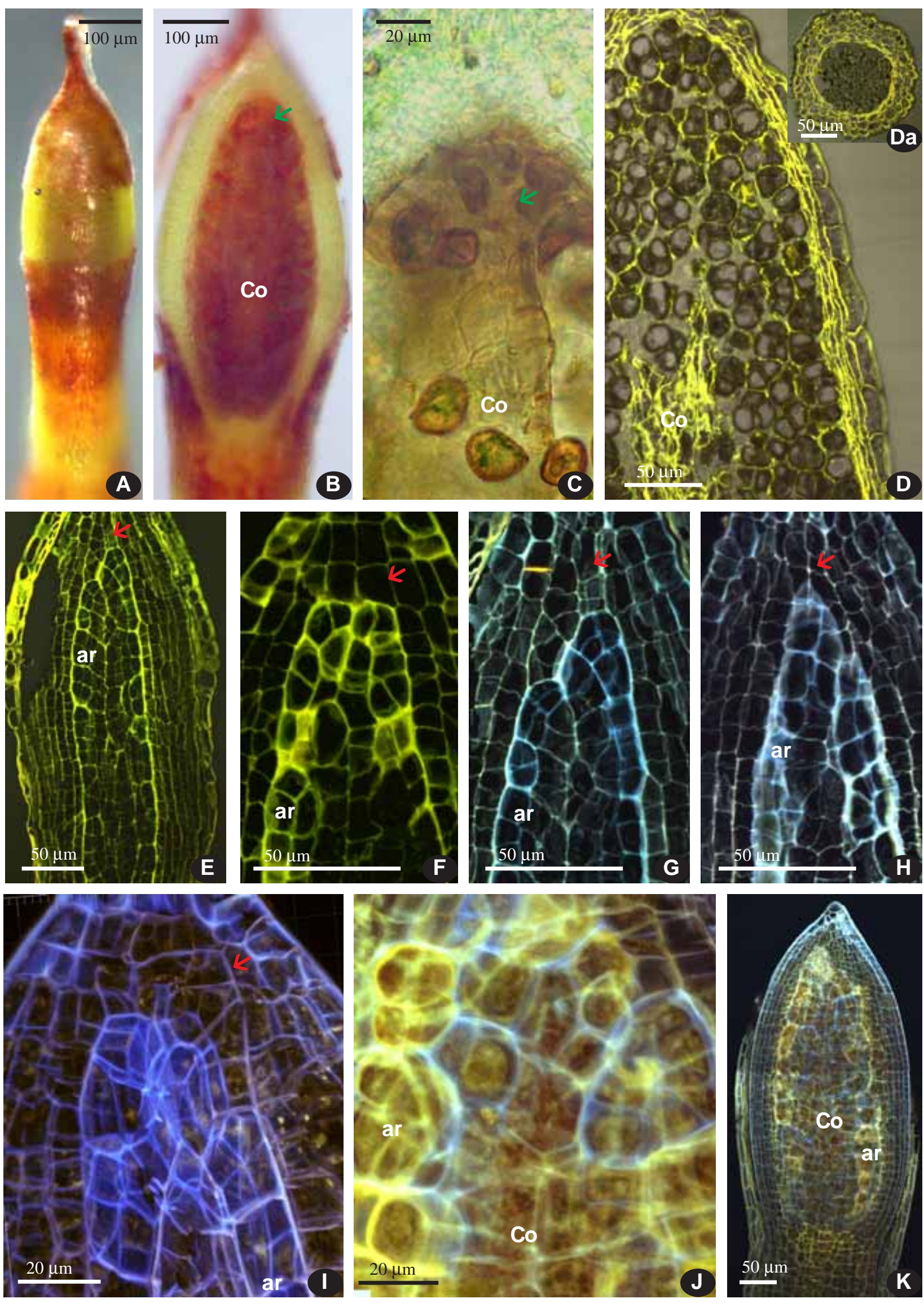

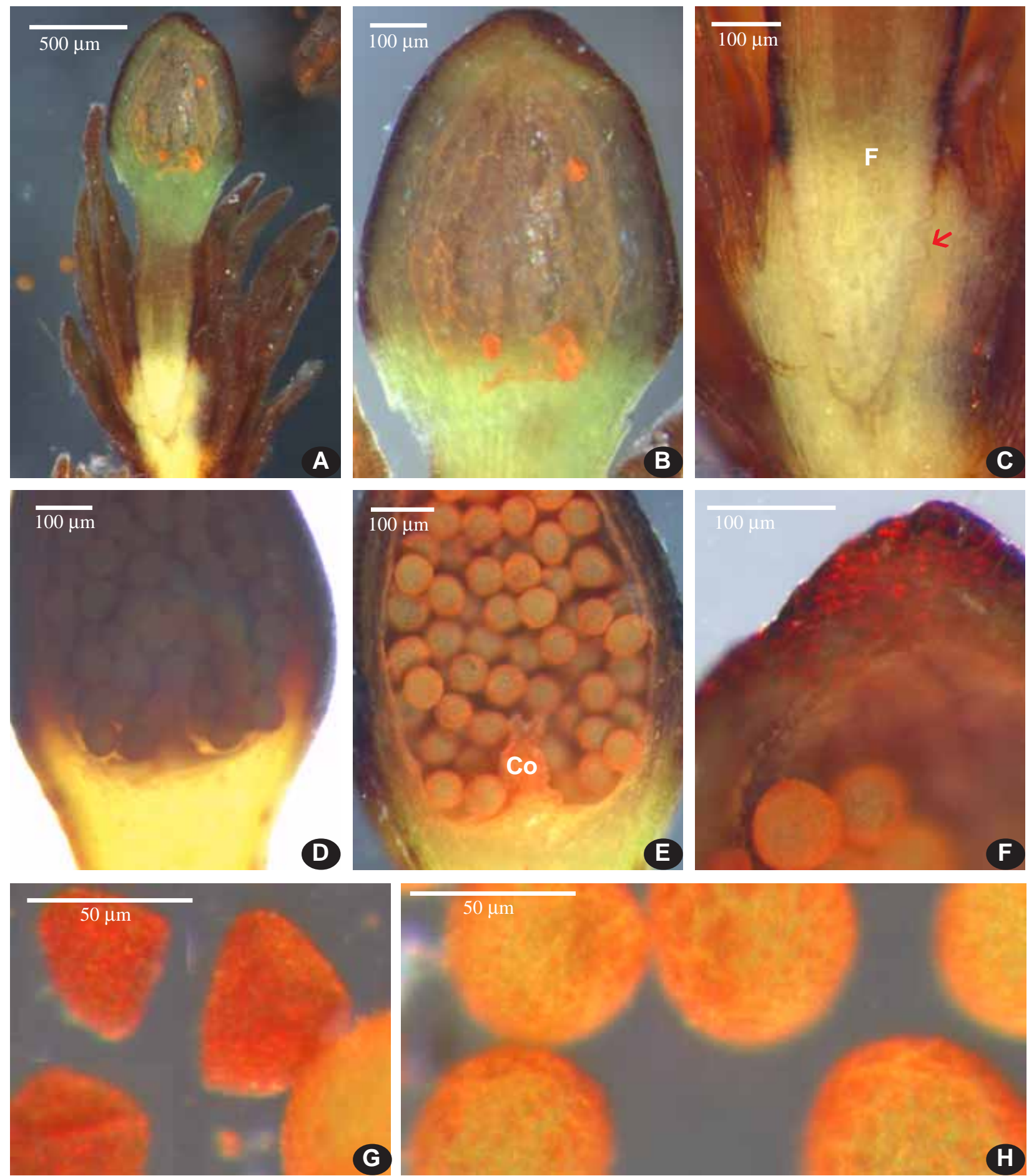

Fig. 30. Andreaeobryum macrosporum (A-H: SM). Photographs are taken from plants stored in glutaraldehyde, without any staining, under halogen light from KL1500 LCD illuminator, on dark grey background, except 'D', which was on white background), additionally contrasting light absorption capacity of the spores, as compared with the urn base; note that ' $D$ ' and ' $E$ ' is the same capsule, differing only by background color. Note also bulging surface (arrowed) of the foot (F) in 'C'. Columella (Co in ' $E$ ') is strongly shrunk at this stage (cf. with Fig. 24). More dense perine in abortive spores (' $G$ ') makes them deeper in color, comparatively with well developed spores in ' $\mathrm{H}$ ', where perine layer is quite uneven.

Fig. 29 (previous page). Andreaea rupestris (A-C: LM, D-K: LCSM). Young capsule view (A) and its longisections (B, with close up and partial spore / remove in C), illustrating connection (arrowed) of columella (Co) with the spore chamber top in ' $\mathrm{C}$ '. ' $\mathrm{D}$ ' and ' $\mathrm{Da}$ ' illustrate columella totally overarching by mature spores (capsule at stage close to dehiscence). ' $E$ '-' $\mathrm{K}$ ' illustrate the upper sectors of undifferentiated endothecium (arrowed) in a position distally from the archesporial tissue (ar), which may form a connection with the top of spore chamber as in ' $\mathrm{C}$ '. 

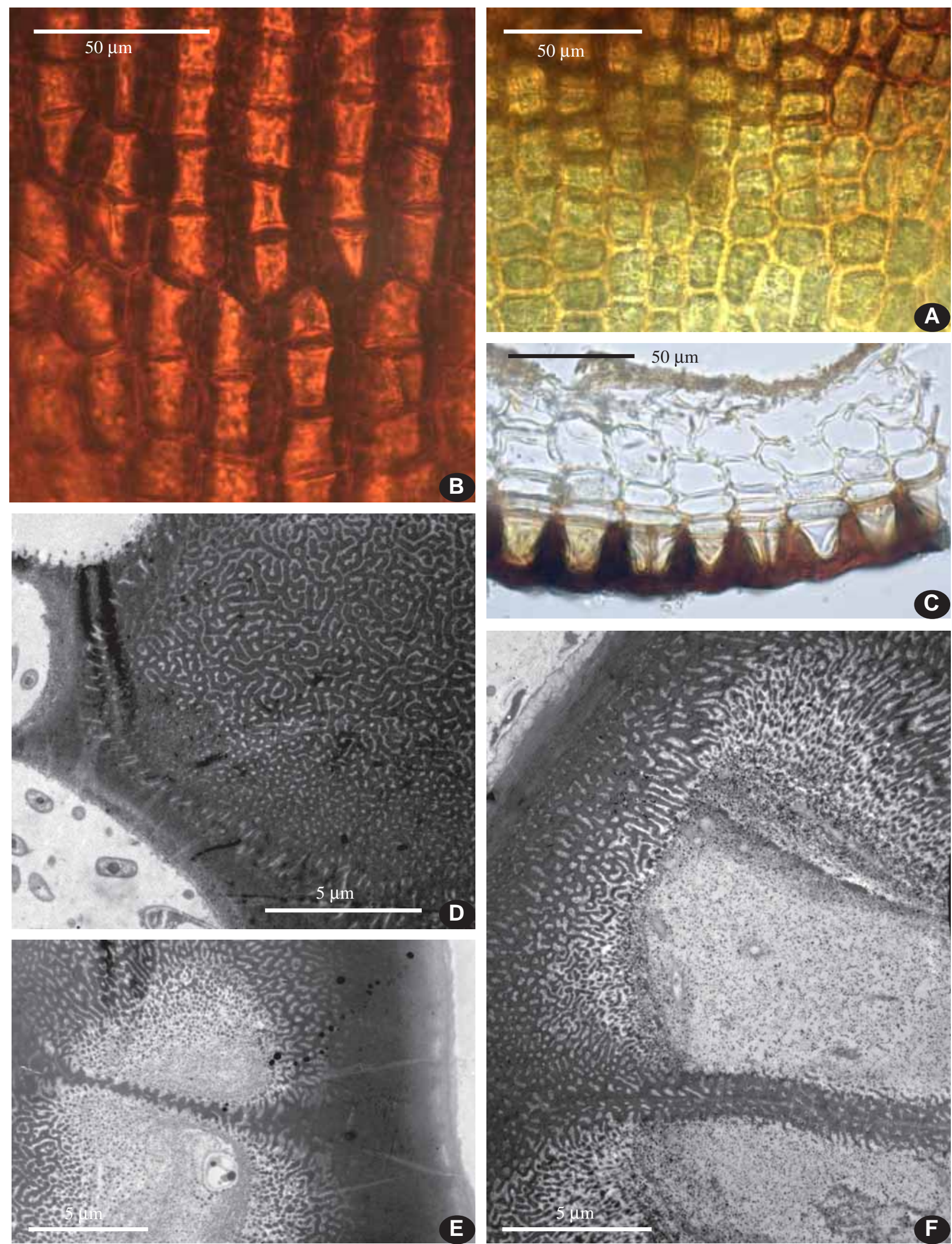

B

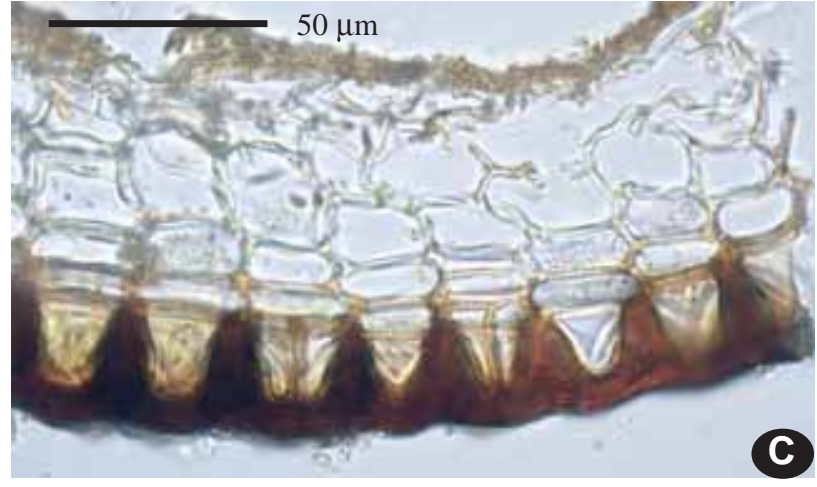

E

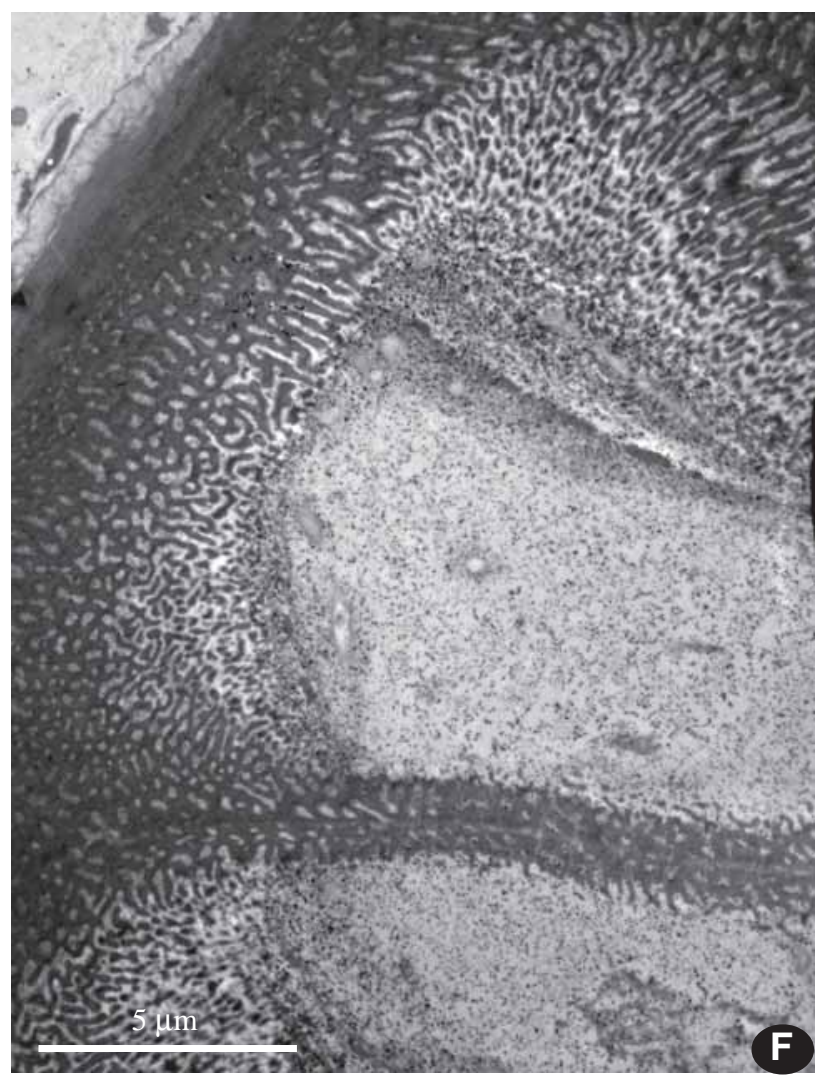

Fig. 31. Andreaeobryum macrosporum (A-C: LM, D-F: TEM). Exothecium structure. A: Lower part of capsule, showing exothecium without stomata, but with a rugose cover, probably of dried mucilage. B: Cover view of upper part of capsule, showing longitudinal thickenings, which sections are shown in 'C-F'. C: Transverse section of the capsule wall, showing thickenings, magnified in 'D-F'. D-F: Sections of the longitudinal thickenings in exothecium: paradermal, longitudinal (somewhat oblique) and transversal, respectively. Combination of the dark osmiophilic vermicular structures embedded in polysaccharide matrix (white medium) provides an high level of light absorption, responsible for the black color of capsules in dry state. 

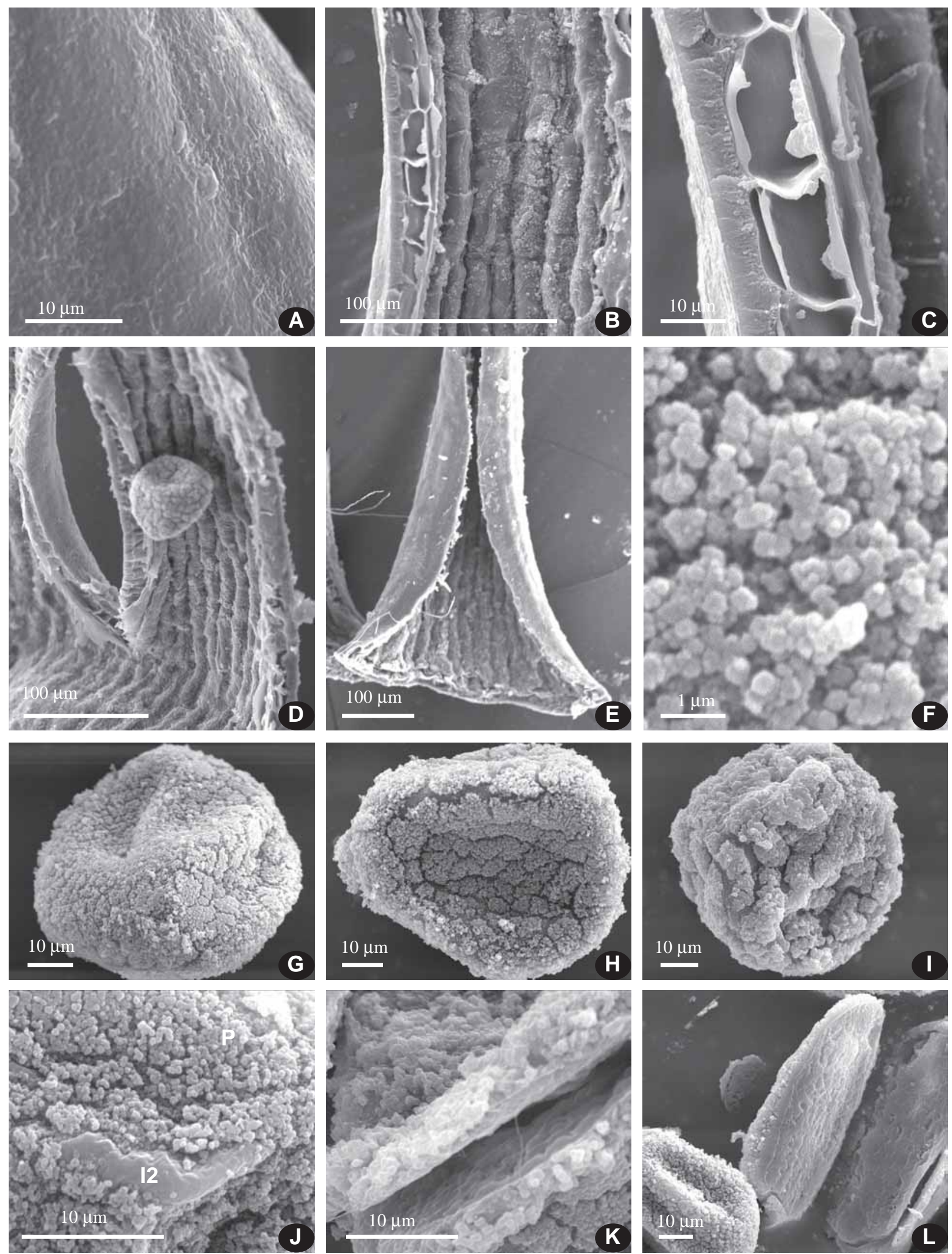

Fig. 32. Andreaeobryum macrosporium spores and capsule surfaces (SEM). A: Outer surface of capsule. B: Capsule from inside; note fine papillae on the outer spore sac surface. C: Longitudinal crack of capsule wall, showing incrassate exothecium. D: A split on the lower part of capsule wall with a spore. E: Separate valve with inrolled margins. F: Capsule from inside, showing ornamentation similar to that on spores. G-I: spores, showing variation. J: Surface of spore somewhat collapsed under vacuum: smooth intine (I2) is seen among finely granulose perine $(\mathrm{P})$. K-L: spore split into two halves, apparently along an internal cell wall, still not incrassate. 

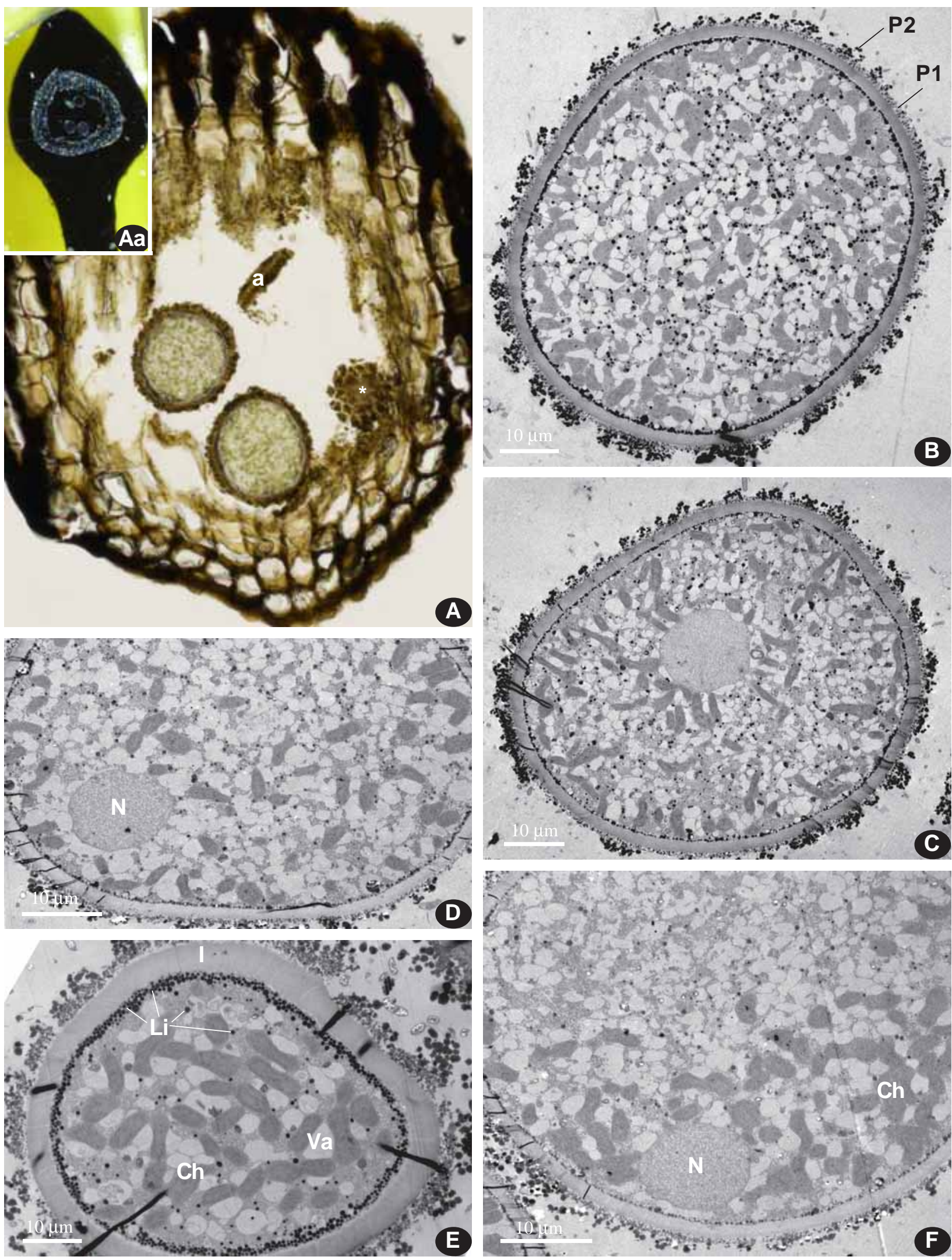

Fig. 33. Andreaeobryum macrosporum spores (A: LM; B-F: TEM). A: Longitudinal section through capsule side, showing longitudinally incrassate exothecial cells distally and rather homogeneous isodiametric cells proximally; two spores are sectioned in their middle, one section $(*)$ through sporoderm and one sectioned spore is abortive (a). B-F: Spore sections, showing variation in chloroplast $(\mathrm{Ch})$ position, evenly spread within spore or more numerous near nucleus $(\mathrm{N})$. All spores have numerous light vacuoles (Va), electron-dark lipid globules (Li), especially abundant near plasmalemma, granulate two-layered perine (P1 and $\mathrm{P} 2$ ), and usually homogenous layer formed by intine (I). 

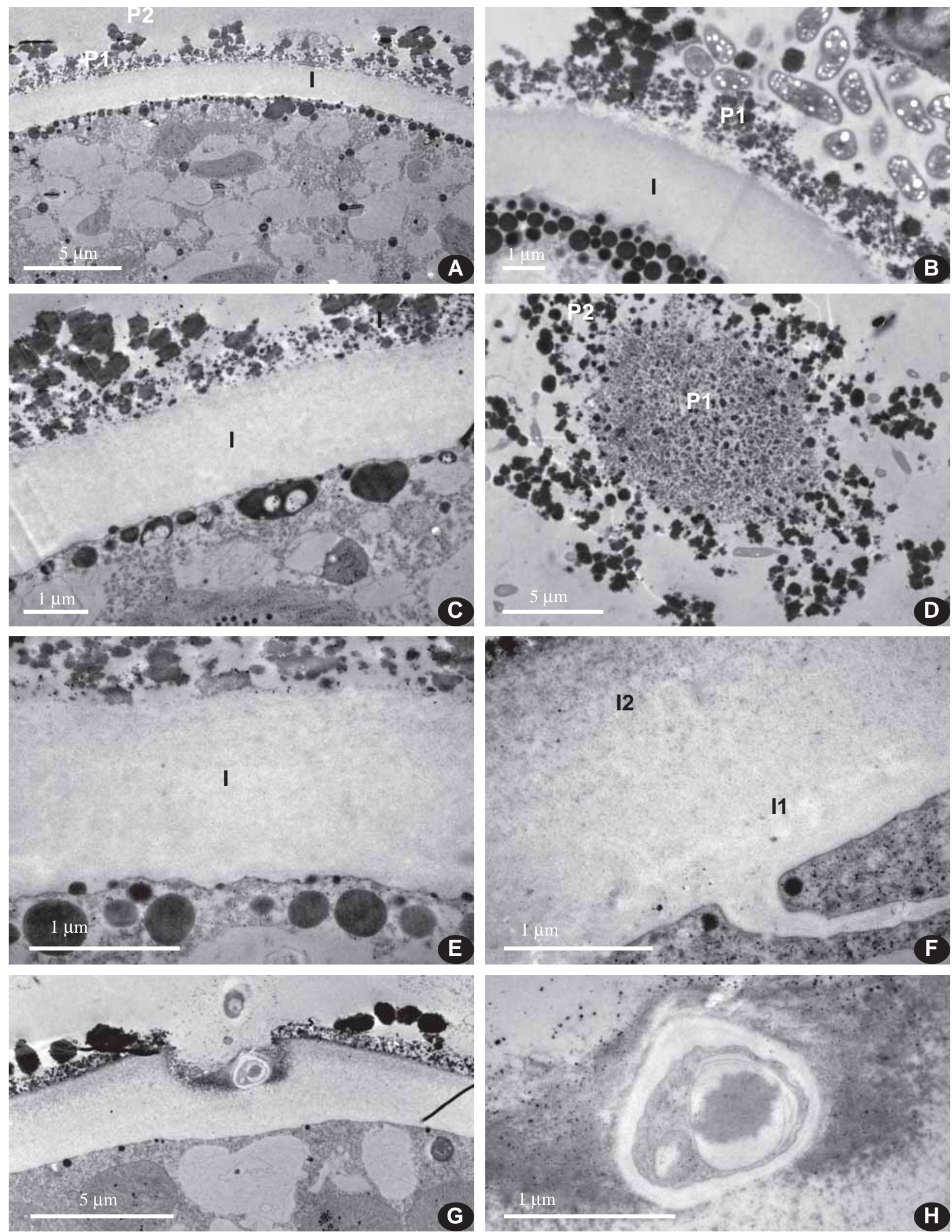

Fig. 34. Andreaeobryum macrosporum, spore ultrastrucure details (TEM). Transverse sections, except the 'D' picture, showing paradermal section, with the electron-dense outer perine (P2) surrounding the inner perine (P1). Photos show a limited variation in sporoderm, composed of more or less homogeneous layer of intine, micro-granulate inner perine and granulate outer perine; plasmalemma is accompanied with numerous osmiophilic globules. F: Spore wall, showing weak differentiation into spotted outer layer and the lighter inner layer, both likely comprising intine, which is continued to the intercellular wall. G-H: a roll-shaped inclusion in the spore wall. 

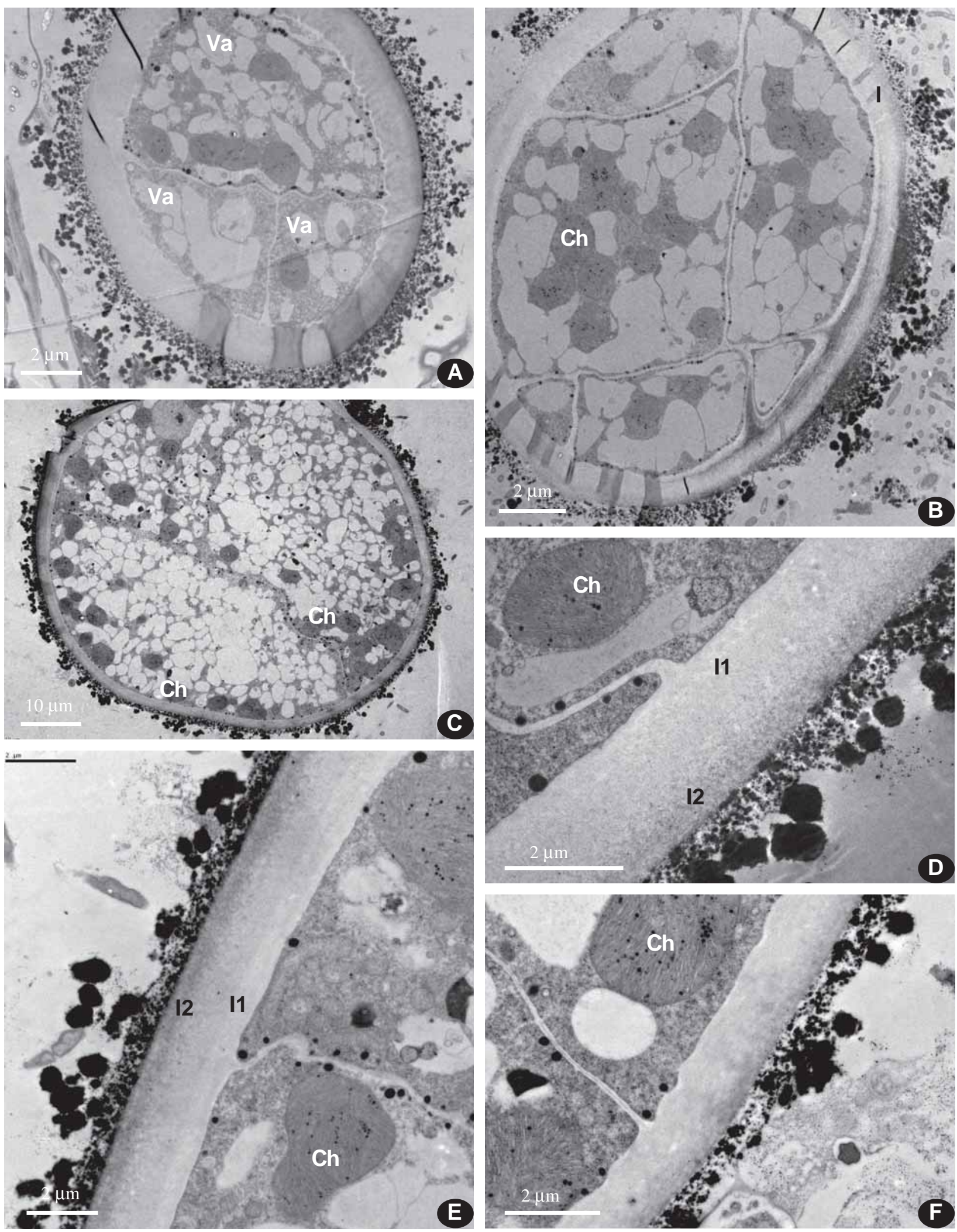

Fig. 35. Andreaeobryum macrosporium, details of the milticellular spore structure (TEM). A: Total section of three-celled spore. In all cells vacuoles (Va) are seen. B: Chloroplasts are seen in the central part, surrounded by vacuoles. C: Chloroplasts (Ch) along the sporoderm and intercellular wall. D-F show junctions of sporoderm with intercellular wall and round chloroplasts near these junctions. 

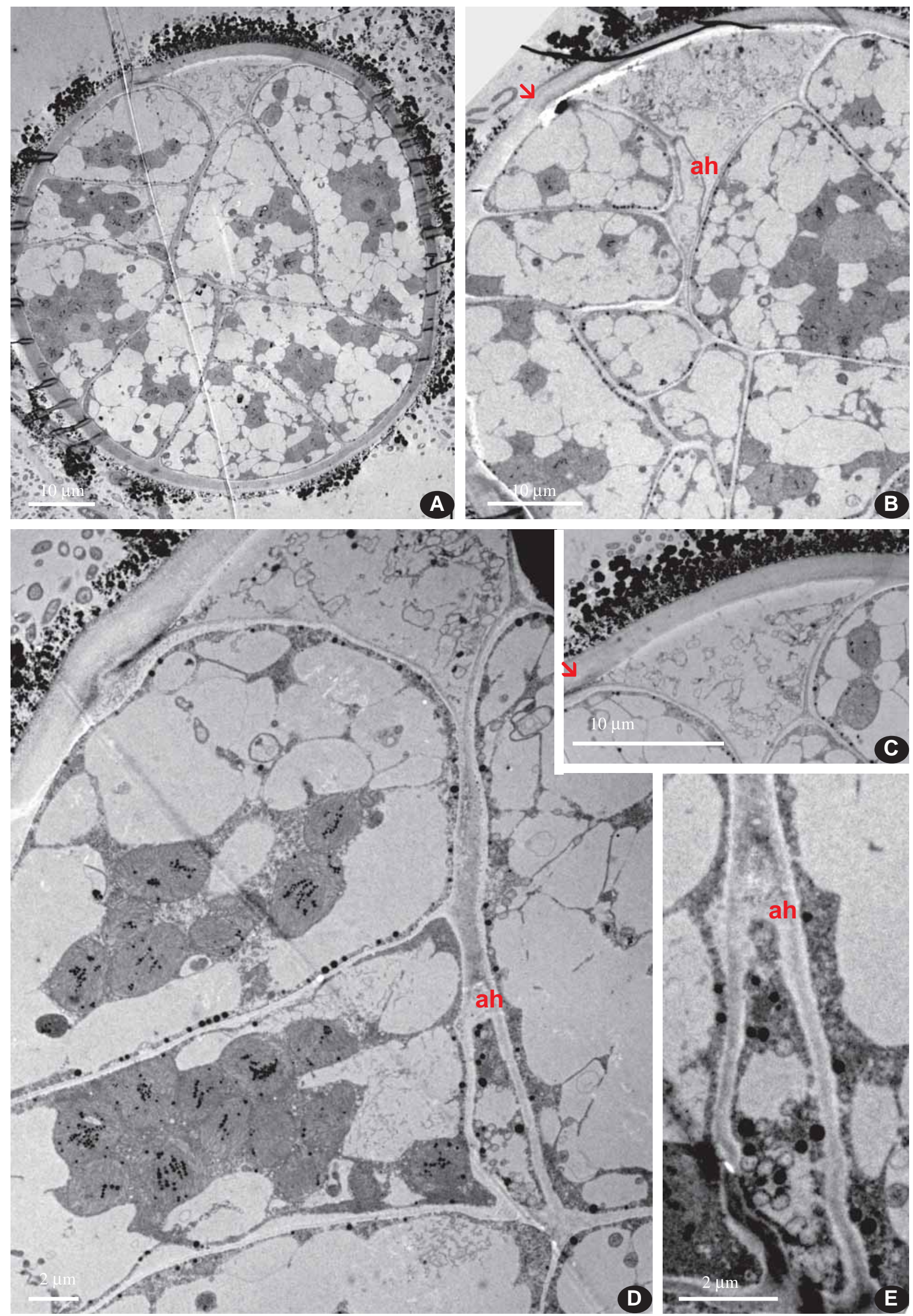

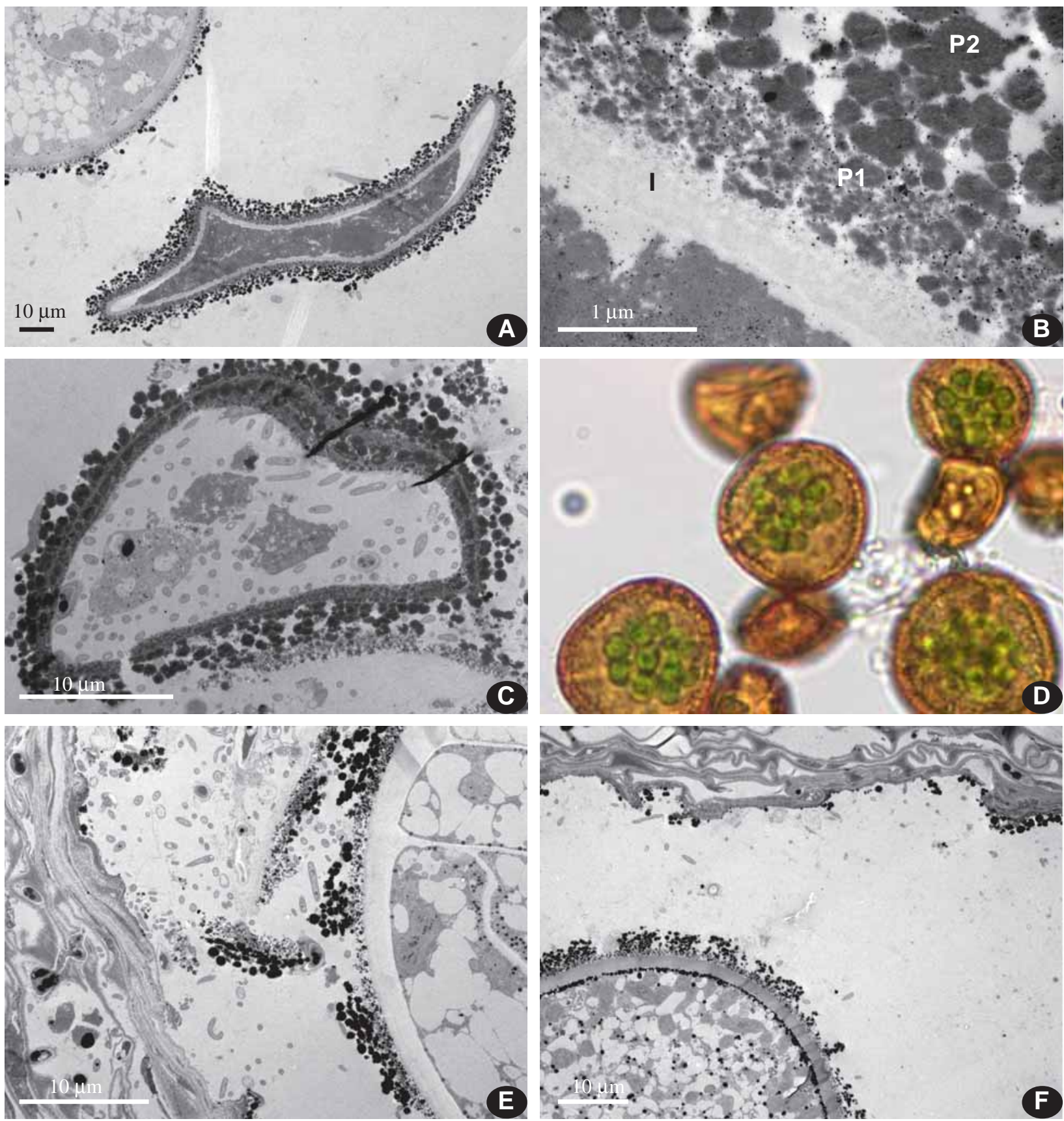

Fig. 37. Andreaeobryum macrosporum (A-C, E-F: TEM) and Andreaea rupestris (D: LM), spore details. A: Section of abortive spore; the spore is flattened and angulose, putatively shaped by pressing within the sporocyte wall in meiosis. No change in sporoderm layers in the area of the tetrahedral mark is seen, however, the characteristic structure of the sporoderm with intine and two-layered perine is well expressed (cf. 'B'); the spore inner contents is dark, without obvious structure. B: Sporoderm ultratructure of the abortive spore, a close up from 'A'. Intine is unevenly thickened, being at places 2-2.5 times thinner than in larger and normally developed spores. C: Abortive and cracked spore with numerous bacteria inside; the spore wall is 'beaded', with globules, in a way somewhat similar to extant Andreaea, cf 'D'. D: Spores from living plants of Andreaea, with rosettes of chloroplasts; note that the sporoderm has a 'beaded' pattern, similar to that in abortive spore in ' $\mathrm{C}$ '. E: Eleven-celled spore side (shown in Fig. 36) near the outer spore sac wall. Note the similarity between perine granules and granules on the spore sac surface: both groups include both dark and light granules; numerous bacteria are seen within the urn. F: Another view on spore and the inner surface of the outer spore sac, showing similarity of granules of their surfaces. Chloroplasts in spore are concentrated shortly below the sporoderm.

Fig. 36. Andreaeobryum macrosporium (previous page) (TEM). Sections of multicellular spore, with eleven cells seen (sections done at a slightly different levels). Light vacuoles and grey chloroplasts are seen in almost all cells and in one cell the nucleus is seen as well. Contrary to other spores, the inner perine is not continuous ('A'), but seems to be split due to spore growth, forming clusters like usually outer perine does; the spore has an internal pool below the place of a putative spore wall rupture in the course of sporeling. Note the putative axillary hair in between cells ('B, D-E'), pointed to narrow channel that is broadening to a pool of intercellular space, where no cellular organelles are discernible. Note also a putative alteration of the intine at the edge of the pool (arrowed). 

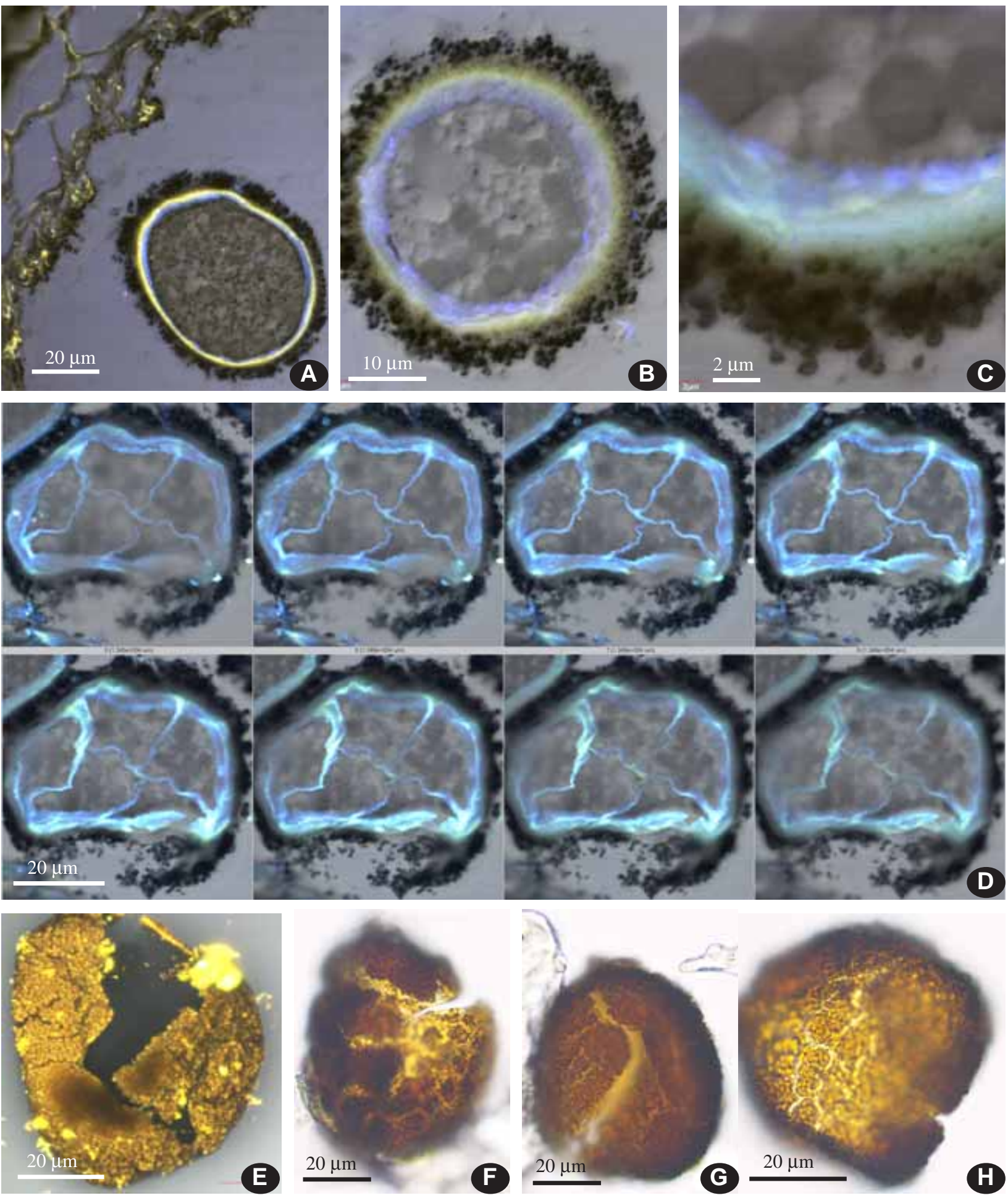

Fig. 38. Andreaeobryum macrosporium, (A-D: LSCM; E-H: LM, acetolized). Acetolized spores show absence of sporopolennin layer (at least continuous enough), thus perine is breaking, partly retaining on P1 layer or outermost I2 layer. A-D: cellulose fluorescence in yellow and premature spore wall material in blue (berberin and DAPI staining). A certain stratification in intine layer is seen, demonstrating its complexity. D: series of micrographs with $2 \mu \mathrm{m}$ interval, through multicellular spore. 

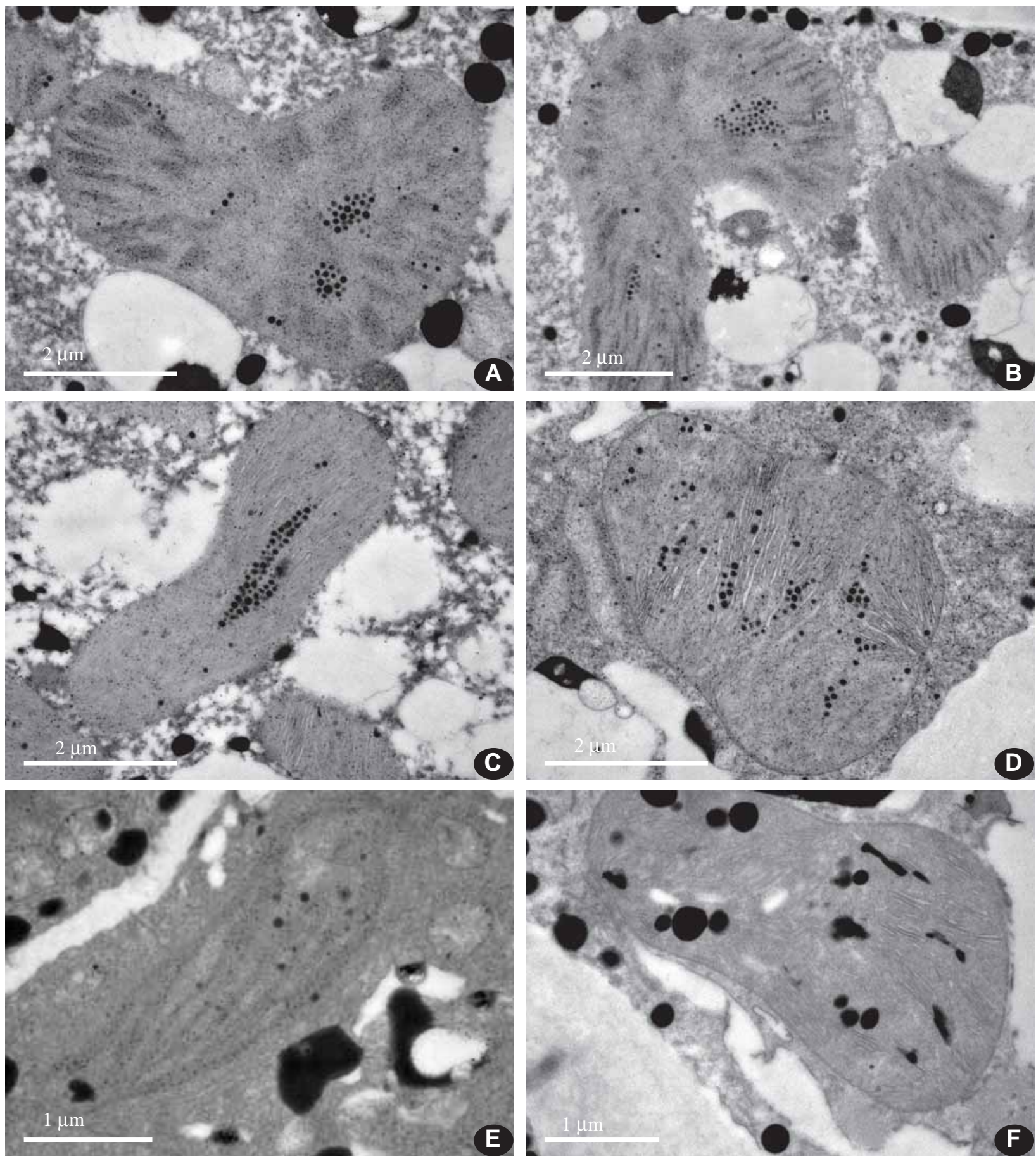

Fig. 39. Andreaeobryum macrosporium, (TEM). A-D: Chloroplasts in spores. E: Chloroplasts in capsule wall. F: Chloroplasts in columella. A: Transverse section, showing cristae and osmiophilic globules, arranged in two bundles. B: Curved chloroplast, with variously directed cristae and bundles of osmiophilic globules. C: Longitudinal section, showing two unequal bundles of osmiophilic globules. D: Transverse section, showing cristae arranged in several compartments in various directions, and osmiophilic globules corresponding to these compartments with only moderate reguliarity. E: Urn wall chloroplast with irregular lipid globules. F: Columella chloroplast with much larger and irregularly arranged osmiophilic globules.

0.1-0.5 $\mu \mathrm{m}$, embedded in electron-transparent medium. The outer layer is usually not continuous and is formed by only osmiophilic globules of larger size, mostly $0.5-$ $2.0 \mu \mathrm{m}$ (Figs. 34-35). Spore wall of acetolized spores breaks into irregular fragments, indicating only a moderately continuous sporopollenin layer (Figs. 38E-H).
In general the spore wall structure in Andreaeobryum is similar to that in Andreaea. Two studies of the development of spore wall were done in A. rothii (Brown \& Lemmon, 1984) and in A. rupestris (Filina \& Filin, 1984). Their results are principally similar, despite their authors followed different terminology. This difference mainly concerned the 
origin of material forming the outer granulose layer, which is usually called perine (Brown \& Lemmon, 1984, 1988; Brown et al., 2015), while Filina \& Filin (1984) considered it to be of the same origin as exine.

In any case, for Andreaea both studies revealed the absence of a lamellate layer, common to other moss groups and important as a starting point for the exine formation (Brown et al., 2015; Schuette et al., 2009). Contrary to this, the exine development in Andreaea starts upon the plasmalemmas by accumulation of osmiophilic globules at various scattered points. These globules grow and join each other, forming a spongy mass. The intine develops later, forming the layer inwards of the exine and also filling the 'caves' and 'holes' among exine material. In the cross sections the exine layer is seen as a mixture of darker bodies of irregular shape (exine) interlayered with the lighter ones (intine) (cf. Brown et al., 2015, plate 7, fig. 1). Intine and perine in Andreaea have a structure similar to that in other mosses, including Andreaeobryum.

Brown \& Lemmon (1988) provided one image of mature spore of Andreaeobryum, where outside a thick intine a scanty exine was recognized, although its segregation was not very clear. Our observations on mature spores do not make possible to delimit exine more clearly. Although the stratification is seen in some images (Figs. 35D-F, 38A-D), it is absent in others, and fluorescent images provide a rather variegated picture, indicating complexity of the spore wall. However, being strongly decomposed in acetolysis, the presence of continuous exine in Andreaeobryum is not confirmed, thus the main content of the homogeneous spore wall in $A n$ dreaeobryum should be referred to intine. Some stratification occurring in few TEM and most of LSCM images thus is interpreted as a two layers of intine, I1 and I2 correspondingly. In most sections, however, intine is marked by just as I, representing undifferentiated electron-translucent major part of the cell wall. Interestingly, occasional occurrence of osmiophilic globules within the intine layer was seen (Figs. 34F, 35F, 36C), and also osmiophilic globules along the inner surface of intine may make its surface wavy (Fig. 34B) or penetrate within intine (Fig. 34C, E).

Upon intine as it defined here, two granulose layers occur (Figs. 33-38), both being quite similar to published picture from American specimen by Brown \& Lemmon (1988, Fig. 37). The outer granulose layer, i.e., formed by globules large in size and looser in arrangement, is similar to perine in other moss groups, while the inner granulose layer requires more attention to understand its homology.

Within the inner granulose layer, the osmiophilic globules occur at least in some places not immediately on the intine surface, but at a certain distance. For example, Fig. 34B illustrates osmiophilic globules scattered in the electron-transparent medium, but at places this electron-light layer lacks dark globules. In other images, e.g. Fig. 35B, the mass of osmiophilic globules is confluent with the outer parts of spore wall.

It is possible to admit that this translucent thin layer corresponds to exine, while osmiophilic globules develop within it. Fig. 37 in publication of Brown \& Lemmon (1988) showed that in tetrad stage, the space between proximal parts of still not separated spores includes numerous dark globules. Their origin is not yet known, but most likely they start to develop within the spore mother cell wall. Filina and Filin (1984) discussing a similar globules in Andreaea (1.c., Fig. 3a) at the stage when tetrad is still within the spore mother cell concluded that they have to be referred to exine rather that perine, since they definitely did not originate from tapetum.

The final conclusion of the homology of layers of the spore wall of Andreaeobryum will be possible only after all the stages of its development have been studied. And likely even after that, the problem with terminology will not disappear, as the places of beginning of globule formation are scattered unlike other mosses. And even if this can be called exine or exine with embedded perine particules (by analogy of exine globules embedded in intine in Andreaea), it would be a very unusual sort of exine. Considered to be one of the most stable structures among living organisms, exine should not be so easily decomposed. At the same time, these is a correlation between the two granulose layers and spore size: the outer granulose layer (P2) looks denser in smaller spores, becoming more spaced in larger spores, where the inner layer (P1) is continuous, but further, with the increase of diameter of multicellular spores, both P1 and P2 appear to be split into polygonal groups and outer intine is exposed, as is seen both in SEM (Fig. 32J) and TEM images (Fig. 36B).

Therefore for present we retain the teminology of Brown \& Lemmon $(1984,1988)$, denoting two granulose layers as inner perine (P1), a mixture of electron-dark osmiophilic and electron-light material, and outer perine (P2), is formed by only osmiophilic globules (Fig. 34).

Spores of Andreaeobryum are large and have the endosporic germination. In some of them up to eleven cells were seen (Fig. 36).

The most unusual fact about spores has been found in an eleven-celled spore (Fig. 36). In its middle, a structure similar in shape to an axillary hair is seen. Its outlines do not perfectly fit, but there is also two cases of indirect evidence supporting its interpretation as an axillary hair. First, Murray's (1988) drawing of the spore germination illustrates simultaneous liberation from the sporoderm of the flat protonema and an axillary hair side by side. Second, the axillary hair in Fig. 36 has a continuation to a channel and then to a pool. The latter does not seem to belong to any cell of the spore, as it lacks any cellular organelles. A putative alteration of the intine occurs at the edge of the pool, marking a place where it is most likely protonema will come out of the spore.

Multicellular spores without trilete mark differentiate 
Andreaeobryum from Takakia, Sphagnum, and Oedipodium (Brown et al., 2015; Polevova, 2015), but are similar to Andreaea. The similarity with the latter genus includes nonpersistent and more or less two-layered perisporium. The perisporium is usually not persistent also in Sphagnum where it may fall off as a whole envelope, releasing the naked spore body with exine as a surface. The perisporium of Oedipodium is poorly developed and falls off the spore surface mostly inside the capsule.

\section{CONCLUSIONS}

Andreaeobryum represents a mixture of characters, consistent with its position as an early-diverging moss lineage. Sporoderm structure, endosporic germination and columella and archesporial tissue patterns are all rather similar to Andreaea. Other characters shared with Andreaea include the absence of stomata and a similar placental structure with transfer cells restricted to the sporophyte. Andreaea and Andreaeobryum also have a similar mechanism of capsule dehiscence by means of longitudinal slits and the sporophyte of Andreaeobryum often approaches a quadrangular configuration.

The gametophytic affinities of Andreaeobryum with other mosses are more complex. Its axillary hairs are completely different from Andreaea. In the latter genus, axillary hairs are of the same type as in all mosses, excepting Takakia, Andreaeobryum and perhaps Sphagnum. However, despite a of certain similarity with Takakia in the apical discharge of mucilage, there are fundamental differences in axillary hair structure between Andreaeobryum and Takakia. Nonetheless abundant mucilage production links Takakia and Andreaobryum, in a similar way to Treubia and Haplomitrium (Duckett et al., 2006).

Another similariarity with Takakia is the ability to substitute a part of a leaf for the development of other organs, an ability also shared with Hepaticae.

Long stalked antheridia of Andreaeobryum are similar to those of Takakia, Sphagnum s.l., Andreaea and Hepaticae, not of other mosses. Antheridia are arranged not only in perigonia, but are found also in the axils of leaves below the perigonium. This is rather unusual in mosses, axillary antheridia otherwise being characteristic of Sphagnopsida and Hepaticae. The apical pore surrounded by thick-walled cells and continuous, rather than explosive, release of spermatozoids are characters not known in other mosses.

Placental structure is similar to Andreaea, Takakia and Polytrichaceae in that cell wall ingrowths in gametophytic cells are absent.

The extensive mucilage-filled placental space in which the entire young sporophyte is embedded for a prolonged period seems to be a unique feature of Andreaeobryum. This character is related to the multistratose calyptra, whose tissues are used for maintaining the medium for early stages of sporophyte development.

The flat seta of Andreaeobryum is unique among bryophytes.

The sectoral columella and archesporial tissue repre- sents a great similarity with Andreaea and Takakia. The former genus is also similar to Andreaeobryum in its compartmentalized spore chamber. The structure of the columella in Andreaeobryum and Andreaea is very similar, and completely different from that of Sphagnum.

Multicellular spores without a trilete mark differentiate Andreaeobryum from Takakia and Sphagnum, but are similar to those of Andreaea. Specific similarities of Andreaeobryum and Andreaea spores include an unstable exfoliating perine and no traces of the tripartite lamellae. A regularly two-layered perisporium is a characteristic of Andreaeobryum and unknown in other mosses.

Endospory occurs in multicellular spores of other mosses, but unique to Andreaeobryum is a rather regular arrangement of cells, differentiation of the axillary hair prior to germination, and the formation of a special pool near the location of protonema liberation from the exosporium.

\section{ACKNOWLEDGEMENTS}

The authors cordially thank Drs. Barbara Murray, Neil Bell and Roy Brown for valuble comments on the manuscript and linguistic suggestions and to Nils Cronberg for the fruitful discussion of some aspects of the manuscript. We are also grateful to Dr. Alexey V. Kostin for consultation on the geology of the studied locality. The work on SEM was performed at User Facilities Center of M.V. Lomonosov Moscow State University under financial support of Ministry of Education and Science of Russian Federation. The work of Ignatov and Voronkova was partially supported by RFBR Project \#16-04-00936, of Fedosov, Ignatova and Polevova by Russian Science Foundation (RNF) (Project No. 14-50-00029), of Ivanova by Biodiversity Project... \#0376-2014-002 and RFBR Project \#15-44-05134.

\section{LITERATURE CITED}

BERTHIER, J., E.-J. BONNOT, M.-C. FABRE \& C. HÉBANT. 1974. L'appareil sécréteur des Bryales: données morphologiques ultrastructurales et cytochimiques. - Bulletin de la Société Botanique de France 121: $97-100$

BROWN, R.C. \& B.E. LEMMON. 1984. Spore wall development in Andreaea (Musci: Andreaeopsida). - American Journal of Botany 71: 412-420.

BROWN, R.C. \& B.E. LEMMON. 1988. Sporogenesis in bryophytes. Advances in Bryology 3: 159-223.

BROWN, R.C. \& B.E. LEMMON. 1990. Sporogenesis in bryophytes. In: Blackmore S., S.H. Barnes (eds.) Pollen and spores: patterns of diversification. Systematics Association Special Volume No. 44: 9-24.

BROWN, R.C., B.E. LEMMON, M. SHIMAMURA, J.C. VILLARREAL AGUILAR \& K.S. RENZAGLIA. 2015. Spores of relictual bryophytes: diverse adaptations to life on land. - Review of Palaeobotany and $\mathrm{Pa}$ lynology 216: 1-17.

CHANG, Y. \& S. W. GRAHAM. 2011. Inferring the higher-order phylogeny of mosses (Bryophyta) and relatives using a large, multigene plastid data set. - American Journal of Botany 98(5): 839-849.

CRANDALL-STOTLER, B.J. 1969. Morphogenetic patterns of branch formation in the leafy Hepaticae - a résumé. - Bryologist 75(4): 381-403.

CRANDALL-STOTLER, B. \& J. J. BOZZOLA. 1990. Ultrastructural details of leaf papillae development in the moss Andreaeobryum macrosporum. - In: Proc. XII Int. Congr. Electron Microscop., San Fran- 
cisco: $670-671$.

DUCKETT, J.G., A. CARAFA \& R. LIGRONE. 2006. A highly differentiated glomeromycotean association with the mucilage-secreting, primitive Antipodean liverwort Treubia (Treubiaceae): clues to the origins of mycorrhizas. - American Journal of Botany 93: 797-813.

DUCKETT, J.G., K.S. RENZAGLIA \& K. PELL. 1990. Desiccation causes the proliferation of multicellular hairs but not mucilage papillae in Cryptothallus mirabilis: a correlated light and electron microscope study. - Canadian Journal of Botany 68: 697-706.

ECKEL, P.M. 2007. Andreaeobryaceae. - In: Flora of North America Editorial Committee (eds.) Flora of North America North of Mexico. Vol. 27: 108-110.

[FILINA, N.I. \& V.R. FILIN] ФИЛИНА Н.И., В.Р. ФИЛИН. 1984. Развитие и строение спородермы Andreaea rupestris Hedw. (Andreaeaceae, Musci). - [The structure and development of the sporoderm in Andreaea rupestris Hedw. (Andreaeaceae, Musci)] Вестник Московского Университета, Сер.16, Биология [Vestnik Moskovskogo Universiteta, Seriya 16, Biologiya] 89: 86-100.

FREY, W., M. HOFMANN \& H.H. HILGER. 2001. The gametophytesporophyte junction: unequivocal hints for two evolutionary lines of archegoniate land plants. - Flora 196: 431-445

GALATIS, B. \& P. APOSTOLAKOS. 1977. On the structure of differentiating mucilage papillae of Marchantia. - Canadian Journal of Botany 55: 772-795.

GOFFINET, B. \& W.R. BUCK. 2004. Systematics of the Bryophyta (mosses): from molecules to a revised classification.-Monographs in Systematic Botany from the Missouri Botanical Garden 98: 205-239.

HEDENÄS, L. 1990. Axillary hairs in pleurocarpous mosses - a comparative study. - Lindbergia 15: 166-180.

HESSE, M., H. HALBRITTER, R. ZETTER, M. WEBER, R. BUCHNER, R.A. FROSCH-RADIVO \& S. ULRICH. 2009. Pollen terminology. - Wien, Springer Verlag, 261 pp.

IGNATOV, M. S., U. N. SPIRINA, E. A. IGNATOVA, M. KRUG \& D. QUANDT. 2015. On the systematic position of the moss genus Catoscopium, with a new approach to the peristome reduction study. Arctoa 24(2): 389-415.

KOZUB, D., V. KHMELIK, YU. SHAPOVAL, V. CHENTSOV, S. YATSENKO, B. LITOVCHENKO \& V. STARYKH. 2008. Helicon Focus Software. - http://www.heliconsoft.com

KÜHN, E. 1874. Zur Entwickelungsgeschichte der Andreaeaceen. - Mittheilungen aus dem gesammtgebiete der Botanik (Leipzig) 1: 1-56+ 10 Tabs.

LIGRONE, R., J.G. DUCKETT \& K.S. RENZAGLIA. 1993. The game- tophyte-sporophyte junction in land plants. - Advances in Botanical Research 19: 231-317.

LIGRONE, R. \& R. GAMBARDELLA. 1988. The sporophyte-gametophyte junction in bryophytes. -Advances in Bryology 3: 225-274.

MURRAY, B.M. 1987. Illustrated moss flora of arctic North America and Greenland. 3. Andreaeobryaceae. - Meddelelser om Grønland, Bioscience 23: 3-6.

MURRAY, B.M. 1988. Systematics of the Andreaeopsida (Bryophyta): two orders with links to Takakia. - Beihefte zur Nova Hedwigia 90: 289-336.

NEWTON, A.E., C.J. COX, J.G. DUCKETT, J.A. WHEELER, B. GOFFINET, T.A.J. HEDDERSON \& B.D. MISHLER. 2000. Evolution of the major moss lineages: phylogenetic analyses based on multiple gene sequences and morphology. - Bryologist 103: 187-211.

POLEVOVA, S. V. 2015. Sporoderm ultrastructure of Oedipodium griffithianum (Oedipodiopsida, Bryophyta). - Arctoa 24(2): 419-430.

RENZAGLIA, K.S., K.D. MCFARLAND \& D.K. SMITH. 1997. Anatomy and ultrastructure of the sporophyte of Takakia ceratophylla (Bryophyta). - American Journal of Botany 84: 1337-1350.

RUHLAND, W. 1924. Musci. Allgemeiner Teil. - In: Engler, A. \& K. Prantl (eds.). Die Natürlichen Pflanzenfamilien. 2, 10. Berlin: Duncker and Humblot: 1-105.

SCHUCK, S., C.M. GALLAGHER \& P. WALTER. 2014. ER-phagy mediates selective degradation of endoplasmic reticulum independently of the core autophagy machinery. - Journal of Cell Science 127: 4078 4088; doi: 10.1242/jcs. 154716 .

SCHUETTE, S., A.J. WOOD, M. GEISLER, J. GEISLER-LEE, R. LIGRONE \& K.S. RENZAGLIA. 2009. Novel localization of callose in the spores of Physcomitrella patens and phylogenomics of the callose synthase gene family. - Annals of Botany 103: 749-756.

SCHUSTER, R.M. 1966. Hepataticae and Anthocerotae of North America, east of hundredth meridian. Vol. 1. - New York, Columbia University Press. $x$ vii +802 pp.

SCHUSTER, R.M. 1971. Two new antipodal species of Haplomitrium (Calobryales). - Bryologist 74(2): 131-143.

SHAW, J. \& K. RENZAGLIA. 2004. Phylogeny and diversification of bryophytes. - American Journal of Botany 91: 1557-1581.

STEERE, W.C. \& B.M. MURRAY. 1976. Andreaeobryum macrosporum, a new genus and species of Musci from northern Alaska and Canada. - Phytologia 33: 407-410.

ZOLOTOV, V.I. \& M.S. IGNATOV. 2001. On the axillary hairs of Leptobryum (Meesiaceae, Musci) and some other acrocarpous mosses. -Arctoa 10: 189-200. 